RECEVED

DEC 289998

\title{
OSTI
}

\section{Enhancing the Use of Coals by Gas Reburning - Sorbent Injection - Volume 5 - Guideline Manual}

\author{
Final Report \\ September 1998
}

Work Performed Under Contract No.: DE-FC22-87PC79796

For

U.S. Department of Energy

Office of Fossil Energy

Federal Energy Technology Center

P.O. Box 880

Morgantown, West Virginia 26507-0880

By

Energy \& Environmental Research Corporation

18 Mason

Irvine, California 92618 


\section{Disclaimer}

This report was prepared as an account of work sponsored by an agency of the United States Government. Neither the United States Government nor any agency thereof, nor any of their employees, makes any warranty, express or implied, or assumes any legal liability or responsibility for the accuracy, completeness, or usefulness of any information, apparatus, product, or process disclosed, or represents that its use would not infringe privately owned rights. Reference herein to any specific commercial product, process, or service by trade name, trademark, manufacturer, or otherwise does not necessarily constitute or imply its endorsement, recommendation, or favoring by the United States Government or any agency thereof. The views and opinions of authors expressed herein do not necessarily state or reflect those of the United States Government or any agency thereof. 


\section{DISCLAIMER}

Portions of this document may be illegible in electronic image products. Images are produced from the best available original document. 


\section{DISCLAIMERS}

\section{U.S. Department of Energy}

This report was prepared by Energy and Environmental Research Corporation pursuant to a cooperative agreement funded partially by the U. S. Department of Energy, and neither Energy and Environmental Research Corporation nor any of its subcontractors nor the U.S. Department of Energy, nor any person acting on behalf of either:

(a) Makes any warranty or representation, express or implied, with respect to the accuracy, completeness, or usefulness of the information contained in this report, or that the use of any information, apparatus, method, or process disclosed in this report may not infringe privately owned rights; or

(b) Assumes any liabilities with respect to the use of, or for damages resulting from the use of, any information, apparatus, method or process disclosed in this report.

Reference herein to any specific product, process, or service by trade name, trademark, manufacturer, or otherwise, does not necessarily constitute or imply its endorsement, recommendation, or favoring by the U. S. Department of Energy. The views and opinions of authors herein do not necessarily state or reflect those of the U. S. Department of Energy.

\section{Gas Research Institute}

LEGAL NOTICE: This report was prepared by Energy and Environmental Research Corporation (EER) as an account of work sponsored by the Gas Research Institute (GRI). Neither GRI, members of GRI, nor any person acting on behalf of either:

a. Makes any warranty or representation, either express or implied, with respect to the accuracy, completeness, or usefulness of the information contained in this report, or that the use of any information, apparatus, method, or process disclosed in this report may not infringe on privately-owned rights; or

b. Assumes any liability with respect to the use of, or for damages resulting from the use of, any information, apparatus, method, or process disclosed in this report. 


\begin{abstract}
The purpose of the Guideline Manual is to provide recommendations for the application of combined gas reburning-sorbent injection (GR-SI) technologies to pre-NSPS boilers. The manual includes design recommendations, performance predictions, economic projections and comparisons with competing technologies. The report also includes an assessment of boiler impacts. Two full-scale demonstrations of gas reburning-sorbent injection form the basis of the Guideline Manual.
\end{abstract}

Under the U.S. Department of Energy's Clean Coal Technology Program (Round 1), a project was completed to demonstrate control of boiler emissions that comprise acid rain precursors, specifically oxides of nitrogen $\left(\mathrm{NO}_{x}\right)$ and sulfur dioxide $\left(\mathrm{SO}_{2}\right)$. Other project sponsors were the Gas Research Institute and the Illinois State Department of Commerce and Community Affairs.

The project involved demonstrating the combined use of Gas Reburning and Sorbent Injection (GR-SI) to assess the air emissions reduction potential of these technologies. Three potential coal-fired utility boiler host sites were evaluated: Illinois Power's tangentially-fired $71 \mathrm{MWe}$ (net) Hennepin Unit \#1, City Water Light and Power's cyclonefired 33 MWe (gross) Lakeside Unit \#7, and Central Illinois Light Company's wall-fired 117 MWe (net) Edwards Unit \#1. Commercial demonstrations were completed on the Hennepin and Lakeside Units. The Edwards Unit was removed from consideration for a site demonstration due to retrofit cost considerations.

Gas Reburning (GR) controls air emissions of $\mathrm{NO}_{\mathrm{x}}$. Natural gas is introduced into the furnace hot flue gas creating a reducing reburning zone to convert $\mathrm{NO}_{\mathrm{x}}$ to diatomic nitrogen $\left(N_{2}\right)$. Overfire air is injected into the furnace above the reburning zone to complete the combustion of the reducing (fuel) gases created in the reburning zone. Sorbent Injection (SI) consists of the injection of dry, calcium-based sorbents into furnace hot flue gas to achieve $\mathrm{SO}_{2}$ capture. 
At each site where the technologies were to be demonstrated, performance goals were set to achieve air emission reductions of 60 percent for $\mathrm{NO}_{x}$ and 50 percent for $\mathrm{SO}_{2}$. These performance goals were exceeded during long term demonstration testing. For the tangentially fired unit, $\mathrm{NO}_{x}$ emissions were reduced by $67.2 \%$ and $\mathrm{SO}_{2}$ emissions by $52.6 \%$. For the cyclone-fired unit, $\mathrm{NO}_{x}$ emissions were reduced by $62.9 \%$ and $\mathrm{SO}_{2}$ emissions by $57.9 \%$. 


\section{ACKNOWLEDGMENTS}

Energy and Environmental Research Corporation (EER) wishes to express appreciation to the project sponsors and their project managers for assistance received in completing this project:

United States Department of Energy - Mr. Harry Ritz and Mr. Jerry Hebb Gas Research Institute - Mr. John Pratapas

Illinois Department of Commerce and Community Affairs - Mr. Paul Pierre Louis

The assistance and cooperation of the following host site electric utilities and their personnel is also greatly appreciated:

Illinois Power Company, especially Mr. T. Jim May and Mr. M. Sam Krueger City Water, Light and Power's Lakeside Station, especially Mr. Tom Booker Central Illinois Light Company 


\title{
-POINTS OF CONTACT
}

For more information regarding Gas Reburning (GR) and Sorbent Injection (SI) technologies, please contact:

\author{
Dr. Blair A. Folsom \\ Senior Vice President \\ Energy and Environmental Research Corporation \\ 18 Mason \\ Irvine, CA 92718 \\ Phone (714) 859-8851 \\ Fax (714) 859-3194 \\ or \\ Mr. Todd M. Sommer \\ Vice President \\ Energy and Environmental Research Corporation \\ 1345 N. Main St. \\ Orrville, $\mathrm{OH} 44667$ \\ Phone (330) 682-4007 \\ Fax (330) 684-2110
}

\section{AUTHORS}

The following EER personnel contributed in the preparation of this report:

Robert A. Ashworth

Donald A. Engelhardt

Blair A. Folsom

Elliott Mecchia

Roy Payne

Todd M. Sommer 


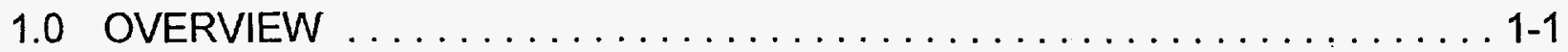

1.1 Purpose of the Report . . . . . . . . . . . . . . . . . . 1-1

1.2 Basis of the Report .......................

1.3 Reference Material . . . . . . . . . . . . . . . . . . . . 1-2

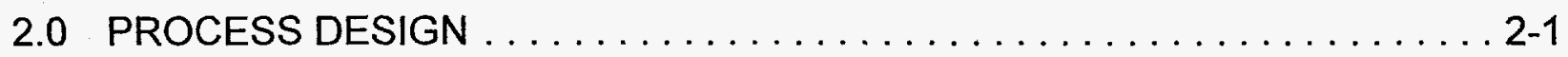

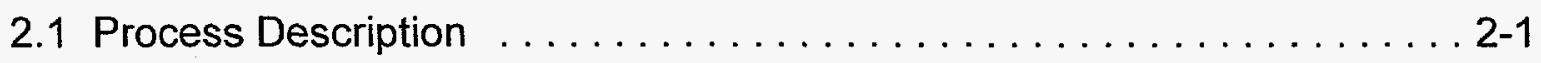

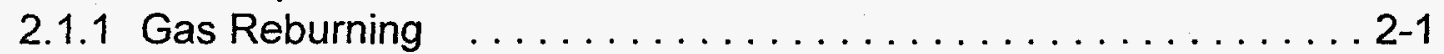

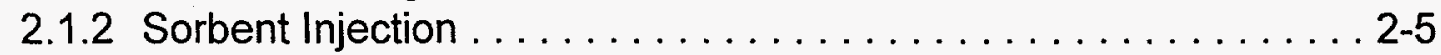

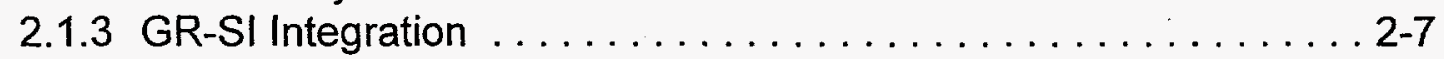

2.2 Process Design Guidelines $\ldots \ldots \ldots \ldots \ldots \ldots \ldots \ldots \ldots \ldots \ldots .2-8$

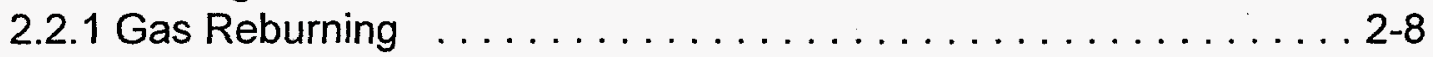

2.2.2 Sorbent Injection $\ldots \ldots \ldots \ldots \ldots \ldots \ldots \ldots \ldots \ldots \ldots \ldots \ldots \ldots \ldots .13$

2.3 Process Design Tools . . . . . . . . . . . . . . . . . . . . . 2 2-19

2.3 .1 Isothermal Flow Modeling $\ldots \ldots \ldots \ldots \ldots \ldots \ldots \ldots \ldots \ldots \ldots \ldots .2-19$

2.3.2 Flow Visualization ......................... 2-20

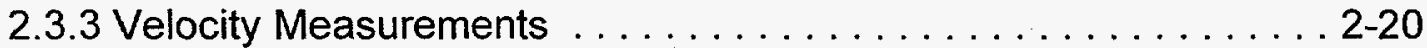

2.3.4 Dispersion Measurements . . . . . . . . . . . . . 2-21

2.3.5 Overall $\mathrm{NO}_{x}$ Reduction Model $\ldots \ldots \ldots \ldots \ldots \ldots \ldots \ldots .2-21$

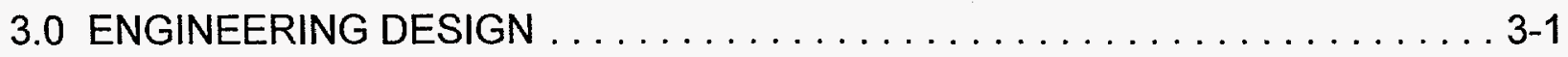

3.1 Gas Reburning System . . . . . . . . . . . . . . . . . . .

3.1.1 Natural Gas System ...................... 3-1

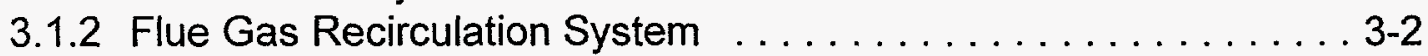

3.1.3 Natural Gas Injection . . . . . . . . . . . . . . . .

3.2 Sorbent Injection System . . . . . . . . . . . . . . . 3-3

3.2.1 Sorbent Storage, Feed, Transport, and Distribution . . . . . . . 3-3

3.2.2 Sorbent Injection . . . . . . . . . . . . . .

3.3 Furnace/Boiler . . . . . . . . . . . . . . . . . . . . . . 3

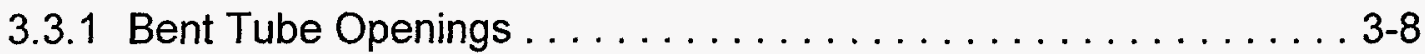

3.3.2 Tube Materials . . . . . . . . . . . . . . . . .

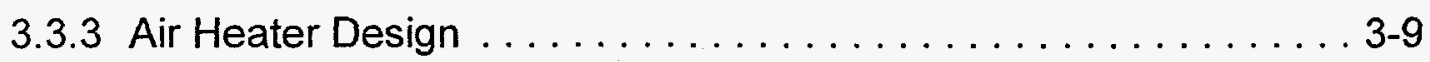


3.3.4 Sootblower Equipment . . . . . . . . . . . . . . . . . 3-10

3.3.5 Combustion Air (Overfire Air Source) . . . . . . . . . . . . 3-11

3.3.6 FGR Source ....................... 3.12

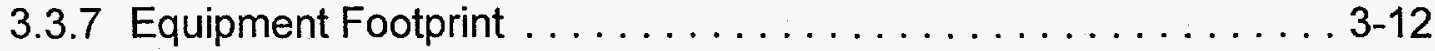

3.3.8 Unit Operation $\ldots \ldots \ldots \ldots \ldots \ldots \ldots \ldots \ldots \ldots \ldots \ldots \ldots \ldots \ldots \ldots \ldots .13$

3.4 Balance of Plant . . . . . . . . . . . . . . . . . . . . . . . . . 3-14

3.4.1 Electrical Power Distribution . . . . . . . . . . . . . . 3-14

3.4 .2 Plant and Instrument Air . . . . . . . . . . . . . . . .

3.4 .3 Controls . . . . . . . . . . . . . . . . . . . . . . . 3-15

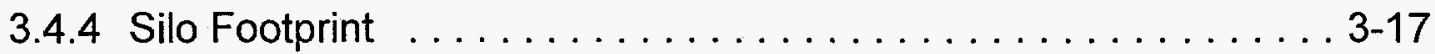

3.4 .5 Particulate Control . . . . . . . . . . . . . . . . 3-17

3.4 .6 Ash Handling . . . . . . . . . . . . . . . . . . . . 3-18

3.4.7 Ash Disposal . . . . . . . . . . . . . . . . . . . . . . . . 3-19

4.0 SYSTEM OPERATION $\ldots \ldots \ldots \ldots \ldots \ldots \ldots \ldots \ldots \ldots \ldots \ldots \ldots .4 .1$

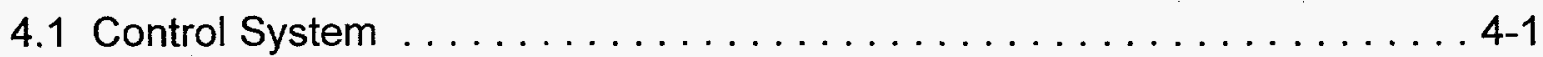

4.2 Operation $\ldots \ldots \ldots \ldots \ldots \ldots \ldots \ldots \ldots \ldots \ldots \ldots \ldots \ldots \ldots .4 .2$

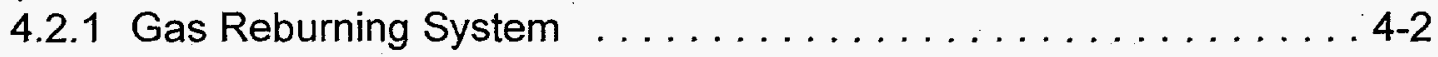

4.2.2 Sorbent Injection System $\ldots \ldots \ldots \ldots \ldots \ldots \ldots \ldots \ldots \ldots \ldots \ldots \ldots$

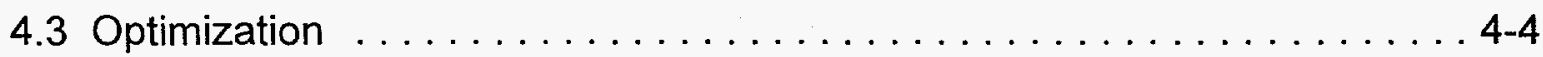

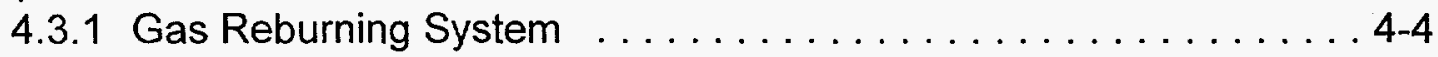

4.3.2 Sorbent Injection System . . . . . . . . . . . . . . . . . 4-7

4.3.3 Gas Reburning-Sorbent Injection System . . . . . . . . . . 4-8

5.0 PROJECT TECHNOLOGY PERFORMANCE $\ldots \ldots \ldots \ldots \ldots \ldots \ldots .5$ 5-1

5.1 Hennepin Unit \#1 GR-SI Demonstration $\ldots \ldots \ldots \ldots \ldots \ldots \ldots \ldots \ldots$. 5-1

5.1 .1 GR Results . ....................... $5-1$

5.1 .2 SI Results ........................... 5-13

5.1 .3 GR-SI Results . . . . . . . . . . . . . . . . . . . . 5-25

5.2 Lakeside Unit \#7 GR-SI Demonstration . . . . . . . . . . . . . . . . 5-26

5.2 .1 GR Results . . . . . . . . . . . . . . . . . . $5 . \ldots \ldots$

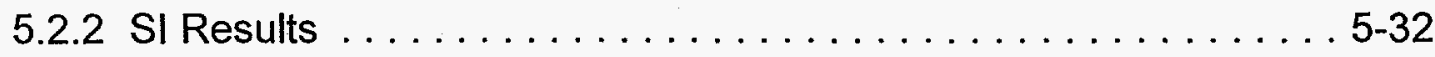

5.2 .3 GR-SI Results . . . . . . . . . . . . . . . . . . . .

5.3 GR-SI Technology Conclusions $\ldots \ldots \ldots \ldots \ldots \ldots \ldots \ldots \ldots \ldots$ 5-39 


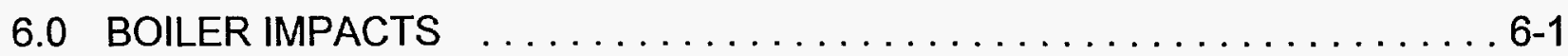

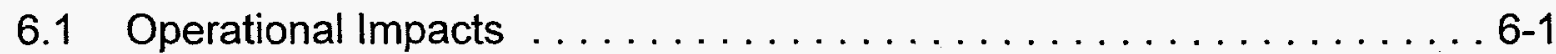

6.1.1 Thermal Performance .......................6-1

6.1 .2 Slagging .......................... 6 .

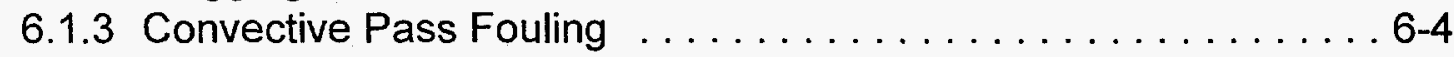

6.1 .4 Auxiliary Power . . . . . . . . . . . . . . . . . . . 6-5

6.1 .5 Cooling Requirements $\ldots \ldots \ldots \ldots \ldots \ldots \ldots \ldots \ldots \ldots$

6.2 Durability . . . . . . . . .

6.2 .1 Boiler Tubes . . . . . . . . . . . . . . . . . . . 6-6

6.2.2 Regenerative Air Heater . . . . . . . . . . . . . . . . . . . . 6-8

6.2 .3 Electrostatic Precipitator . . . . . . . . . . . . . . . . .

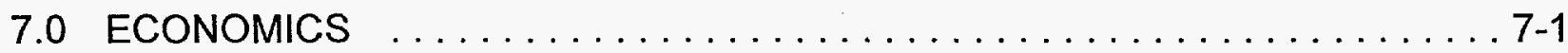

7.1 Gas Reburning System $\ldots \ldots \ldots \ldots \ldots \ldots \ldots \ldots \ldots . . \ldots \ldots .1$

7.1.1 GR - Economic Parameters . . . . . . . . . . . . . . . . .

7.1.2 GR - Estimated Process Capital Cost . . . . . . . . . . 7-2

7.1.3 GR - Projected Operating and Maintenance Costs . . . . . . 7-4

7.1.4 GR - Summary of Performance and Economics . . . . . . . . 7-8

7.1.5 GR - Effect of Variables on Economics .............. 7-11

7.1.6 GR - Comparison with other $\mathrm{NO}_{x}$ Control Technologies . . . . 7-12

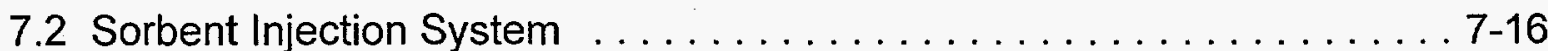

7.2.1 SI - Economic Parameters . . . . . . . . . . . . . . . . . . .

7.2.2 SI - Estimated Process Capital Cost . . . . . . . . . . . 7-17

7.2.3 SI - Projected Operating and Maintenance Costs . . . . . . . . 7-19

7.2.4 SI - Summary of Performance and Economics . . . . . . . . . 7-19

$7.2 .5 \mathrm{SI}$ - Effect of Variables on Economics .............. 7-21

7.2.6 SI - Comparison with other $\mathrm{SO}_{2}$ Control Technologies ...... 7-23

\section{REFERENCES}

BIBLIOGRAPHY 


\section{LIST OF TABLES}

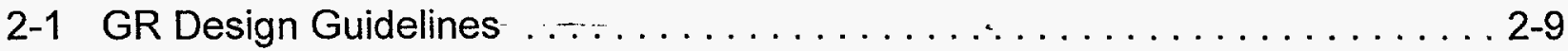

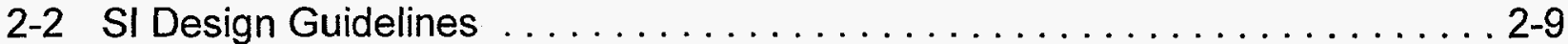

7-1 300 MWe Cyclone-fired Unit GR Retrofit Capital Cost . . . . . . . . . . . . . . 7-5

7-2 $300 \mathrm{MWe}$ Cyclone-fired Unit GR Retrofit Operating Cost $\ldots \ldots \ldots \ldots \ldots$ 7-7

7-3 Economic Factors . . . . . . . . . . . . . . . . . . . . . . . . 7-9

7-4 GR Retrofit Cost and Performance Summary $\ldots \ldots \ldots \ldots \ldots \ldots \ldots \ldots$ 7-10

7-5 Cost of $\mathrm{NO}_{x}$ Removal . . . . . . . . . . . . . . . . . . . . . . .

7-6 Reburning Fuel Comparison .......................... . 7-13

7-7 400 MWe Cyclone-fired $\mathrm{NO}_{x}$ Control Comparison .............. . 7-16

7-8 300 MWe Cyclone-fired Unit SI Retrofit Capital Cost . . . . . . . . . . . . . . 7-18

7-9 300 MWe Cyclone-fired Unit SI Retrofit Operating Cost . . . . . . . . . . . 7-20

7-10 SI Retrofit Cost and Performance Summary . . . . . . . . . . . . 7-22

7-11 Cost of $\mathrm{SO}_{2}$ Removal . . . . . . . . . . . . . . . . . . . .

7-12 SI Comparison with other $\mathrm{SO}_{2}$ Control Options $\ldots \ldots \ldots \ldots \ldots \ldots \ldots .7-28$

\section{LIST OF FIGURES}

2-1 Schematic of GR-SI System ........................ 2-3

2-2 GR-SI Simplified Process Flow Diagram .................. 2-6

5-1 Baseline and Gas Reburning $\mathrm{NO}_{\mathrm{x}}$ and $\mathrm{CO}$ emissions $\ldots \ldots \ldots \ldots \ldots \ldots$ 5-2

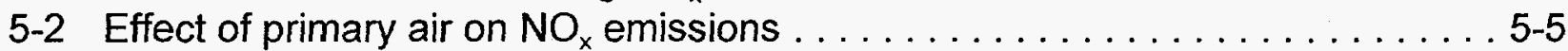

5-3 Effect of reburning zone stoichiometry on $\mathrm{NO}_{\mathrm{x}}$ emissions $\ldots \ldots \ldots \ldots \ldots$ 5-6

5-4 $\mathrm{NO}_{\mathrm{x}}$ reduction and $\mathrm{CO}$ emissions with Gas Reburning $\ldots \ldots \ldots \ldots \ldots \ldots$ 5-7

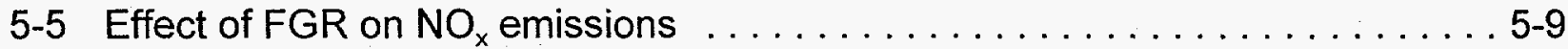

5-6 Effect of burner tilt on $\mathrm{NO}_{x}$ emissions . . . . . . . . . . . . . . . 5-11

5-7 Effect of boiler load on $\mathrm{NO}_{\mathrm{x}}$ emissions . . . . . . . . . . . . . . . .

5-8 Effect of mills out of service at low loads . . . . . . . . . . . . . 5-14

5-9 Effect of reburn zone $\mathrm{SR}$ and temperature on $\mathrm{NO}_{x}$ emissions . . . . . . 5-15

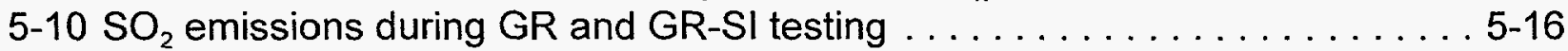

$5-11 \mathrm{SO}_{2}$ reduction with $\mathrm{GR}-\mathrm{SI}$ for three load ranges $\ldots \ldots \ldots \ldots \ldots \ldots \ldots \ldots$ 5-19

5-12 Calcium utilization with GR-SI for three load ranges . . . . . . . . . . 5-21

$5-13$ Effect of $\mathrm{SI}$ jet configuration on calcium utilization . . . . . . . . . . 5-22

5-14 Effect of burner tilt on calcium utilization at low load . . . . . . . . . . 5-24

5-15 Effect of primary air and reburn zone SRs on NOx emissions at full load . . 5 5-27

5-16 Effect of exit zone stoichiometry on $\mathrm{NO}_{x}$ and $\mathrm{CO}$ at full load . . . . . . . . 5-29

5-17 Effect of exit zone stoichiometry on $\mathrm{NO}_{x}$ and $\mathrm{CO}$ at mid and low load . . . . . 5-30

5-18 Effect of reburn fuel injector design on $\mathrm{NO}_{x}$ emissions at mid and low load . . 5-31

5-19 Effect of FGR on $\mathrm{NO}_{x}$ emissions at full and mid loads . . . . . . . . . . 5-33

5-20 Effect of FGR on $\mathrm{NO}_{\mathrm{x}}$ emissions at low loads . . . . . . . . . . . 5-34

5-21 Effect of $\mathrm{Ca} / \mathrm{S}$ ratio on $\mathrm{SO}_{2}$ emissions with $\mathrm{SI}$ only $\ldots \ldots \ldots \ldots \ldots \ldots$ 5-36

5-22 Effect of $\mathrm{Ca} / \mathrm{S}$ ratio on $\mathrm{SO}_{2}$ emissions with GR-SI . . . . . . . . . . . . 5-37

$5-23$ Effect of $\mathrm{Ca} / \mathrm{S}$ ratio on calcium utilization . . . . . . . . . . . . . . . 5-38

5-24 Effect of $\mathrm{SI}$ injection air rate on $\mathrm{SO}_{2}$ emissions . . . . . . . . . . . 5-40

5-25 (a) Long term testing $\mathrm{NO}_{\mathrm{x}}$ emissions reduction . . . . . . . . . . . . . . . 5-41

5-25 (b) Long term testing $\mathrm{SO}_{2}$ emissions reduction . . . . . . . . . . 5-41 


\section{LIST OF ABBREVIATIONS}

$\begin{array}{ll}\text { CAAA } & \text { Clean Air Act Amendments } \\ \text { CCT } & \text { Clean Coal Technology } \\ \text { CRT } & \text { Cathode Ray Tube } \\ \text { CWLP } & \text { City, Water, Light and Power City of Springfield, IL. } \\ \text { EER } & \text { Energy and Environmental Research Corporation } \\ \text { EPA } & \text { Environmental Protection Agency } \\ \text { ESP } & \text { Electrostatic Precipitator } \\ \text { FGD } & \text { Flue Gas Desulfurization } \\ \text { FGR } & \text { Flue Gas Recirculation } \\ \text { GR } & \text { Gas Reburning } \\ \text { GR-SI } & \text { Gas Reburning-Sorbent Injection } \\ \text { HAR } & \text { Heat Absorption Ratio } \\ \text { HVT } & \text { High Velocity Temperature } \\ \text { NFPA } & \text { National Fire Protection Association } \\ \text { NSPS } & \text { New Source Performance Standards } \\ \text { OFA } & \text { Overfire Air } \\ \text { OTR } & \text { Ozone Transport Region } \\ \text { PFR } & \text { Plug Flow Reactor } \\ \text { PRB } & \text { Powder River Basin } \\ \text { PSD } & \text { Prevention of Significant Deterioration } \\ \text { RACT } & \text { Reasonable Available Control Technology } \\ \text { SCR } & \text { Selective Catalytic Reduction } \\ \text { SI } & \text { Sorbent Injection } \\ \text { SNCR } & \text { Selective Non-Catalytic Reduction } \\ \text { SR } & \text { Air:fuel Stoichiometric Ratio } \\ \text { WSR } & \text { Well Stirred Reactor }\end{array}$




\section{LIST OF UNITS}

acfm

Btu

${ }^{\circ} \mathrm{F}$

$\mathrm{ft}^{3}$

gal

in

$\mathrm{kW}$

kWe

$\mathrm{kWh}$

Ib

$\mathrm{lbs} / \mathrm{hr}$

MW

MWe

psig

ton/yr

W.C.

$10^{6} \mathrm{Btu}$

I

$\%$

Actual Cubic Foot per Minute

British Thermal Unit

Degree Fahrenheit

Cubic Foot

Gallon

Inch

Kilowatt

Kilowatt Electric

Kilowatt Hour

Pound

Pound per Hour

Megawatt

Megawatt Electric

Pound per Square Inch (Gauge)

Ton per Year

Water Column

Million Btu

Inch

Percent

\section{GLOSSARY OF TERMS}

$\begin{array}{ll}\mathrm{C}_{2} \mathrm{H}_{2} & \text { Acetylene } \\ \mathrm{C}_{2} \mathrm{H}_{4} & \text { Ethylene } \\ \mathrm{Ca}(\mathrm{OH})_{2} & \text { Calcium Hydroxide } \\ \mathrm{CH} & \text { Hydrocarbon Radical } \\ \mathrm{CH}_{2} & \text { Hydrocarbon Radical } \\ \mathrm{CH}_{4} & \text { Methane } \\ \mathrm{CO} & \text { Carbon Monoxide } \\ \mathrm{CO} & \text { Carbon Dioxide } \\ \mathrm{Fe} & \text { Iron } \\ \mathrm{H}_{2} & \text { Hydrogen (Diatomic) } \\ \mathrm{H}_{2} \mathrm{~S} & \text { Hydrogen Sulfide } \\ \mathrm{H}_{2} \mathrm{O} & \text { Water } \\ \mathrm{N}_{2} & \text { Nitrogen (Diatomic) } \\ \mathrm{NH}_{3} & \text { Ammonia } \\ \mathrm{NO}_{x} & \text { Nitrogen Oxides } \\ \mathrm{O}_{2} & \text { Oxygen (Diatomic) } \\ \mathrm{S}_{\mathrm{SO}_{2}} & \text { Sulfur } \\ \mathrm{SO}_{2} & \text { Sulfur Dioxide }\end{array}$




\section{EXECUTIVE SUMMARY}

The purpose of the Guideline Manual is to provide recommendations for the application of combined gas reburning-sorbent injection (GR-SI) technologies to pre-NSPS boilers. The manual includes design recommendations, performance predictions, economic projections and comparisons with competing technologies. The report also includes an assessment of boiler impacts. Two full-scale demonstrations of gas reburning-sorbent injection form the basis of the Guideline Manual. A GR-SI demonstration was completed on Illinois Power Company's Hennepin Unit \#1. It is a $71 \mathrm{MW}_{\mathrm{e}}$ (net) tangentially fired utility boiler and the primary fuel is an Illinois Bituminous coal containing approximately $3 \mathrm{wt} \%$ sulfur. A second GR-SI demonstration was completed at City Water, Light and Power's Lakeside Station Unit \#7, located in Springfield, Illinois. Unit \#7 is a $33 \mathrm{MW}_{\mathrm{e}}$ cyclone-fired unit that burns medium to high sulfur Illinois Bituminous coal.

Gas Reburning (GR) involves reducing the levels of coal and combustion air in the burner area and injecting natural gas above the burners followed by the injection of overfire air (OFA) above the reburning zone. This three-zone process creates a reducing area in the boiler furnace within which $\mathrm{NO}_{\mathrm{x}}$ created in the primary zone is reduced to elemental nitrogen and other less harmful nitrogen species. Each zone has a unique stoichiometric ratio (ratio of air to that theoretically required for complete combustion) as determined by the flow of coal, burner air, natural gas, and OFA.

Sorbent Injection (SI) technology controls $\mathrm{SO}_{2}$ emissions through injection of a calciumbased sorbent such as hydrated lime $\left[\mathrm{Ca}\left(\mathrm{OH}_{2}\right)\right]$ into the boiler furnace where it reacts with gaseous $\mathrm{SO}_{2}$ to form solid calcium sulfate. This compound is then removed from the flue gas in the baghouse or electrostatic precipitator.

GR and $\mathrm{SI}$ are applied simultaneously to achieve combined $\mathrm{NO}_{\mathrm{x}}$ and $\mathrm{SO}_{2}$ control. Although significantly reducing the $\mathrm{NO}_{x}$ emissions, $\mathrm{GR}$ also achieves an incremental 
reduction in $\mathrm{SO}_{2}$ emissions, - since natural gas contains no sulfur. This complements the $\mathrm{SO}_{2}$ reduction of the $\mathrm{SI}$ process and reduces the amount of sorbent otherwise required.

\section{Process Design}

The process design for application of GR-SI technology is developed according to a generalized methodology involving the application of various experimental and analytical tools. Functional design requirements are based on characteristics of the subject boiler, the GR-SI process requirements, and the system performance goals. Process considerations that are essential to the design and practical application of the reburning system are: the reburn zone stoichiometric ratio, the temperature (or location) at which the natural gas is injected, the OFA injection location, and any impacts on boiler thermal performance. Rapid and complete mixing of the injected reactants with the local furnace gases is critical to the successful application of the GR-SI process. Detailed information concerning the flow field of the subject boiler can be accomplished by isothermal flow modeling. Flow visualization is accomplished using smoke and neutrally buoyant bubble injection. Velocity measurements are made within the model using hot wire anemometer and Kurtz probe instrumentation. The hot wire anemometer is used with observations of the yarn tufts to produce velocity and mass distribution profiles at various measurement planes in the model. Dispersion measurements are made to determine the degree of mixing at locations downstream of a proposed natural gas, OFA, or SI configuration.

\section{Engineering Design}

Installation of a GR-SI system involves retrofit of the equipment onto an existing boiler. Due consideration must be given to design of the following items and areas:

- Supply of natural gas, pressure, piping size requirements

- Mass flow rate requirement for flue gas recirculation (if needed) 
- Injector configuration vs. boiler structural constraints

- Cooling medium for injectors

- Sorbent storage and transport system vs. material selection

- Boiler tubewall penetrations

- Existing regenerative air heater design

- Capacity of sootblowing system

- Equipment footprint

- Electrical power distribution

- Plant and instrument air

- Existing controls system

- Existing particulate control system

- Existing ash handling and disposal system

\section{System Operation}

Control and monitoring of the GR-SI system was accomplished through a Westinghouse Electric Process Control WDPF system. The system consists of a variable mix of functional units (drops) communicating freely and rapidly via the WDPF Data Highway. The WDPF sends and receives signals from various components in the GR-SI system, in addition to interfacing with other microprocessors.

The GR system is composed of three integrated systems: (1) natural gas injection, (2) FGR, and (3) OFA injection. The natural gas flow rate is controlled to the desired value for optimum $\mathrm{NO}_{\mathrm{x}}$ destruction. The FGR flow is controlled to a value to give the natural gas momentum for optimum distribution in the furnace. The OFA is controlled to a value to complete combustion of all unburned fuel leaving the reburning zone. The three integrated systems were interlocked, operated and monitored by the WDPF control system. The SI system variables were modulated by the WDPF control system to obtain a target sulfur 
emission reduction while maintaining maximum sorbent utilization. The GR-SI control system worked well as designed.

\section{Technology Performance}

The GR-SI process involves the injection of reburning fuel (in this case natural gas) into the furnace above the coal burners for reduction of nitrogen oxides $\left(\mathrm{NO}_{\mathrm{x}}\right)$ and injection of dry sorbent into the upper furnace for capture of sulfur dioxide $\left(\mathrm{SO}_{2}\right)$. During field evaluations, a wide range of boiler operating conditions and GR-SI parameters were tested to determine the optimum conditions for $\mathrm{NO}_{x}$ and $\mathrm{SO}_{2}$ emission reductions. The project goals of 60 and $50 \%$ reductions in $\mathrm{NO}_{x}$ and $\mathrm{SO}_{2}$, respectively, were achieved for both demonstrations.

One of the GR-SI demonstrations was completed on Illinois Power Company's Hennepin Unit \#1. The pre-GR-SI baseline $\mathrm{NO}_{x}$ was $0.75 \mathrm{lb} \mathrm{NO} \mathrm{x}_{\mathrm{x}} / 10^{6} \mathrm{Btu}(323 \mathrm{mg} / \mathrm{MJ}$ ) at full load. GR parametric tests showed $\mathrm{NO}_{x}$ emissions ranging from a low of $0.19 \mathrm{lb} / 10^{6} \mathrm{Btu}(81$ $\mathrm{mg} / \mathrm{MJ}$ ) to a high of $0.36 \mathrm{lb} / 10^{6} \mathrm{Btu}(157 \mathrm{mg} / \mathrm{MJ}$ ) over the operating limits of gas heat inputs ranging from 10 to $22 \%$, primary zone airffuel stoichiometric ratios ranging from 1.06 to 1.15 , and reburn zone stoichiometric ratios ranging from 0.88 to 1.01 . The GR system was designed to maximize $\mathrm{NO}_{x}$ emission reductions for an $18-20 \%$ reburn gas heat input. The goal was to achieve a minimum of $60 \% \mathrm{NO}_{\mathrm{x}}$ reduction and long term testing at full load yielded an average $\mathrm{NO}_{x}$ reduction of $67 \%$.

Baseline $\mathrm{SO}_{2}$ emissions averaged $5.24 \mathrm{lb} / 10^{6} \mathrm{Btu}(2,250 \mathrm{mg} / \mathrm{MJ})$ and sorbent $\mathrm{SO}_{2}$ capture ranged from a low of $25.3 \%$ to a high of $60.6 \%$. GR testing only showed the expected $\mathrm{SO}_{2}$ reductions, with 8 and $12 \%$ reburn gas heat input compared to baseline, 8 to $13 \% \mathrm{SO}_{2}$ reductions occurred. The GR-SI test, showed an $\mathrm{SO}_{2}$ reduction of $52.6 \%$, when operating with $18 \%$ reburn gas heat input and a Ca/S of 1.57 . 
Fly ash samples were collected to evaluate carbon loss. At a primary zone air:fuel stoichiometric ratio (SR) above 1.06, carbon in fly ash varied from 2.2 to $5.2 \%$ compared to the baseline value of $2.6 \%$. The unit could be run at a primary zone SR of 1.07 and above and maintain the low carbon-in-ash seen for baseline operation.

A second GR-SI demonstration was completed at City Water, Light and Power's Lakeside Station Unit \#7. The baseline $\mathrm{NO}_{\mathrm{x}}$ for Lakeside Unit \#7 was $0.97 \mathrm{lb} / 10^{6} \mathrm{Btu}$. Testing showed that operation at a primary SR of 1.08 and reburning zone SR of 0.83 resulted in the highest $\mathrm{NO}_{\mathrm{x}}$ reduction at full load $(67 \%)$, while operation at a primary zone SR of 1.15 and reburning zone SR of 0.90 achieved the target $\mathrm{NO}_{x}$ reduction of $60 \%$.

Furnace $\mathrm{SI}$ was designed to achieve $\mathrm{SO}_{2}$ reductions in the 25 to $50 \%$ range. When combined with $\mathrm{GR}$, higher $\mathrm{SO}_{2}$ reductions occur due to coal replacement with natural gas. Reductions in $\mathrm{SO}_{2}$ were calculated from the $5.9 \mathrm{lb} / 10^{6} \mathrm{Btu}(2540 \mathrm{mg} / \mathrm{MJ})$ baseline. The $\mathrm{SO}_{2}$ emission reductions under SI-only operation, for the range of load 19 to $34 \mathrm{MW}_{\mathrm{e}}$ were $25 \%$ at a $\mathrm{Ca} / \mathrm{S}$ of 1.1 and $42 \%$ at a $\mathrm{Ca} / \mathrm{S}$ of 2.1 . Under $\mathrm{GR}-\mathrm{SI}$ operation with gas heat inputs of 22 to $25 \%, \mathrm{SO}_{2}$ reductions were $51 \%$ at a Ca/S of 1.1 and $61 \%$ at a $\mathrm{Ca} / \mathrm{S}$ of 2.1 . In the majority of GR-SI tests, with 22 to $25 \%$ gas heat input, the goal of achieving a $50 \% \mathrm{SO}_{2}$ reduction was achieved. The maximum $\mathrm{SO}_{2}$ reduction measured under $\mathrm{GR}-\mathrm{SI}$ was $68 \%$ at a $\mathrm{Ca} / \mathrm{S}$ of 2.09 and gas heat input of $23 \%$.

\section{Boiler Impacts}

In steam generating units, the heat released from combustion of fuels must be absorbed by heat exchangers with high efficiency. GR operation can affect the thermal performance of the unit in two ways. First, GR affects the furnace heat release profile and second, GR operation changes local stoichiometric ratios and particulate loading resulting in minor changes in lower and upper furnace deposition patterns. The demonstrations showed that the overall impact of GR operation on the heat absorption profile was very minor. There 
was a reduction in thermal efficiency of approximately $1 \%$ due to the increased $\mathrm{H} / \mathrm{C}$ ratio of the natural gas compared to coal which resulted in more moisture heat loss to the atmosphere. During SI operation, there were reductions in convective heat absorption due to sorbent fouling, especially in the generating bank. Near continual use of sootblowers were required to remove deposits and maintain steam temperatures. The increased particulate loading also caused a shift in heat absorption from the furnace and upper convective pass to the convective backpass. This shift had the following impacts:

- Reduction in thermal efficiency (approximately $1.2 \%$ )

- Increase in temperature and velocity of the flue gas

- Higher fly ash resistivity that reduced the collection efficiency of the ESP

These demonstrations, however, showed that GR-SI operation does not exacerbate slagging in the furnace. Some buildup of slag in the lower furnace, from the top burner elevation to the OFA ports did occur, but not the excessive levels seen with baseline operation. Little change in upper furnace slagging was observed. Injection of natural gas and FGR did promote slag accumulations around the nozzles forming "eyebrows" and on the waterwall areas above the natural gas/FGR injectors. Periodic manual cleaning (nominally weekly) was sufficient to maintain normal GR operation.

During GR, approximately $10-20 \%$ of the coal fuel is replaced by natural gas. The use of gas allows for a corresponding reduction in coal usage, reducing mechanical wear on the coal processing equipment. Normal rates of tube wastage in coal-fired boilers are in the range of $0.001 "$ to 0.003 " per year. During the two field demonstrations one-year tests were conducted to evaluate tube wastage. Following extensive mechanical testing and statistical evaluation, it was concluded that there was no significant tube wastage in the boilers nor was any metallurgical degradation was found. 
Further, no adverse conditions in the air heater were noted as a direct result of GR-SI operation. However, SI required an increase in sootblowing which could have a degrading effect on the air heater.

Particulate decreases proportionally to the amount of natural gas used with GR. However, a marked increase occurs with SI. For this reason it was necessary to perform an evaluation of the ESP, prior to installation of SI, to verify that it had sufficient capacity to handle the increased particulate loading. Due to ESP limitations, humidification was required for Hennepin Unit \#1 and kept particulate emissions to pre-GR-SI emission levels.

\section{Economics}

Capital and operating costs for the GR system for $\mathrm{NO}_{x}$ emissions reduction and the $\mathrm{SI}$ system for $\mathrm{SO}_{2}$ emissions reduction were completed for the retrofit of a $300 \mathrm{MWe}$ coal cyclone-fired power plant. The reason for selecting a cyclone-fired unit is that there are not many low cost NOx control options for these type of units. The degree of complexity regarding retrofit costs were factored based on the retrofit costs for the GR-SI demonstrations completed under this DOE contract. These two systems were treated as separate technologies; the only major synergistic effect of the GR system on the SI system is the reduction of $\mathrm{SO}_{2}$ based on the replacement of sulfur-containing coal with natural gas devoid of sulfur. Economic projections were made using current dollars which include an inflation rate of $4.0 \%$, and constant dollars which ignore inflation.

\section{Gas Reburning}

Table 1 shows the performance and cost for a 300 MWe GR System that is retro-fitted to a cyclone-fired boiler. NOx reduction costs are based on a $65 \%$ capacity factor with $20.1 \%$ of the heat input supplied by natural gas at a gas to coal price differential of $\$ 1.00 / \mathrm{million}$ Btu. The incremental increase in the levelized cost of power, including capital charges 
TABLE 1. 300 MWe.GR RETROFIT PERFORMANCE AND COST

\section{Summary of Data}

Power Plant Attributes

Plant capacity, net

Power produced, net

Capacity factor

Plant life

Coal feed

Sulfur in Coal

$\begin{array}{cc}\text { Units } & \text { Value } \\ \mathrm{MWe} & 300 \\ 10^{9} \mathrm{kWhr} / \mathrm{yr} & 1.71 \\ \% & 65 \\ \mathrm{yr} & 15 \\ \text { tons/yr } & 683,280 \\ \text { wt\% } & 3.0\end{array}$

Removal efficiency

Emissions Control Data

Emissions standard

Emissions without controls

Emissions with controls

Amount reduced

$\begin{array}{cc}\text { Units } & \text { NOx } \\ \% & 67.0 \\ \mathrm{lb} / 10^{6} \mathrm{Btu} & 0.86 \\ \mathrm{lb} / 10^{6} \mathrm{Btu} & 1.30 \\ \mathrm{lb} / 10^{6} \mathrm{Btu} & 0.43 \\ \text { tons/yr } & 7,439\end{array}$

\section{Levelized Cost of Power}

Current Dollars

Capital Charge

Factor

Mills/kWhr

0.160

0.47

1.314

0.22

1.314

2.99

Variable Operating Cost

3.69

1.314

$(0.58)$

3.11

\section{Constant Dollars}

Factor

Mills/kWhr

$\mathrm{SO}_{2}$ Credits

0.124

0.37

1.000

0.17

1.000

2.28

2.81

1.000

2.37

\section{Levelized Cost - NOx Removal Basis \\ \$/ton \\ Factor removed \\ $\$$ /ton \\ Factor \\ removed}

Capital Charge
Fixed O\&M
Variable Operating Cost
Total Cost
$\mathrm{SO}_{2}$ Credits
Total Cost w/SO
2 Credits

0.160

109

0.124

84

1.314

51

1.314

687

847

1.000

39

1.000

523

1.314

713

1.000

(101)

544

Basis: $67 \%$ NOx reduction assumed based on larger unit with longer Reburn zone residence time than CWLP 33 MWe cyclone unit ( $58 \%$ NOx reduction w/20\% gas heat input as Reburn fuel). 
is estimated at $2.81 \mathrm{mills} / \mathrm{kWhr}$ in constant dollars and 3.69 mills/kWhr in current dollars. If an $\mathrm{SO}_{2}$ credit is applied based on a sulfur reduction when firing natural gas, the net incremental increase in the levelized cost of power is estimated at $2.37 \mathrm{mills} / \mathrm{kWhr}$ in constant dollars and 3.11 mills/kWhr in current dollars. The levelized cost of $\mathrm{NO}_{x}$ removal is estimated at $\$ 646 /$ ton and $\$ 847 /$ ton for current and constant dollar projections, respectively. If an $\mathrm{SO}_{2}$ credit is applied based on fuel sulfur reduction, the net levelized cost of $\mathrm{NO}_{\mathrm{x}}$ removal is estimated at $\$ 544 /$ ton and $\$ 713 /$ ton for current and constant dollar projections, respectively.

An independent study completed for the U.S. EPA, "Investigation of Performance and Cost of $\mathrm{NO}_{x}$ Controls as Applied to Group 2 Boilers", compared the costs of competing $\mathrm{NO}_{x}$ control technologies. The costs for various $\mathrm{NO}_{x}$ reduction systems applied to cyclone-fired units were developed as part of this study. The cost of Gas Reburning, Coal Reburning, Selective Non-Catalytic Reduction (SNCR) and Selective Catalytic Reduction (SCR), based on $\$ / \mathrm{kWe}$ and $\$ /$ ton of $\mathrm{NO}_{\mathrm{x}}$ removed are shown for $400 \mathrm{MWe}$ cyclone-fired units. As shown in Table 2, the cyclone-fired boiler $\mathrm{NO}_{x}$ control technologies show a cost per ton of $\mathrm{NO}_{x}$ removed that ranges from approximately $\$ 490$ to $\$ 690$.

TABLE 2. 400 MWe CYCLONE-FIRED NO ${ }_{x}$ CONTROL COMPARISON

\begin{tabular}{||l|c|c|c||}
\hline \multicolumn{1}{|c|}{ Technology } & $\begin{array}{c}\text { NOx Reduced } \\
\%\end{array}$ & $\begin{array}{c}\text { Capital Cost } \\
\$ / \mathrm{kWe}\end{array}$ & $\begin{array}{c}\mathrm{NO}_{\mathrm{x}} \text { Removed }^{4} \\
\$ / \text { ton }\end{array}$ \\
\hline Gas Reburning & & 590 \\
\hline Coal Reburning & 60 & 15.2 & 490 \\
\hline $\mathrm{SNCR}^{2}$ & 50 & 52.7 & 690 \\
\hline $\mathrm{SCR}^{3}$ & 35 & 7.3 & 575 \\
\hline
\end{tabular}

(1) Natural Gas @ $\$ 2.47 / 10^{6}$ Btu and Coal @ $\$ 1.47 / 10^{6}$ Btu

(2) $50 \%$ Urea solution @ \$0.50/gal

(3) Anhydrous Ammonia @ \$162/ton \& SCR catalyst replacement (3 yr life) @ \$350/ft ${ }^{3}$ 
Based on this comparison Coat-Reburning is the least.expensive and SNCR the most expensive with GR and SCR being near equal when the price differential between natural gas and the primary coal is $\$ 1.00 / 10^{6} \mathrm{Btu}$. The $\mathrm{NO}_{x}$ reduction for $\mathrm{SCR}$ assumed for this study was low, only $50 \%$. However, SCR systems have achieved $85 \%+$ reductions with increased catalyst volume.

\section{Sorbent Injection}

The SI system was designed to store, meter, and convey micronized hydrated lime (sorbent) to the injection nozzles in the upper furnace of the $300 \mathrm{MWe}$ cyclone-fired Unit. The SI system is comprised of the following major components: sorbent storage silo, weigh hopper, rotary valve feeder, screw pump, air transport blower, conveying line, sorbent splitter, SI air fan, and furnace injection nozzles.

Economic projections were made using current dollars, which include an inflation rate of $4.0 \%$, and constant dollars which ignore inflation. Table 3 shows the performance and cost for an SI System that is retro-fitted to a $300 \mathrm{MWe}$ cyclone-fired boiler. The incremental increase in the levelized cost of power is estimated at $5.32 \mathrm{mills} / \mathrm{kWhr}$ in constant dollars and 6.98 mills $/ \mathrm{kWhr}$ in current dollars. The levelized cost of $\mathrm{SO}_{2}$ removal is estimated at $\$ 490 /$ ton and $\$ 643 /$ ton for constant and current dollar projections, respectively.

The primary methods of coal-fired utilities used in complying with the 1990 Clean Air Act Amendments (CAAA) include switching from high sulfur Eastern coal to low sulfur Western coal, purchase of $\mathrm{SO}_{2}$ allowance credits and stack gas scrubbing. With relatively lower capital costs and higher operating costs as compared to the wet scrubbing systems, SI might be suited for application to aging plants with low capacity factors or relatively short operating lives. To reach compliance when using SI, utilities may consider allowance purchasing, or scrubbing on newer units in their system. The $\mathrm{SO}_{2}$ removal cost of $\mathrm{SI}$ is compared to wet scrubbers, coal switching and $\mathrm{SO}_{2}$ allowance credits in Table 4 . 


\section{Summary of Data}

\section{Power Plant Attributes}

Plant capacity, net

Power produced, net

Capacity factor

Plant life

Coal feed

Sulfur in coal

Removal efficiency

Emissions standard

Emissions without controls

Emissions with SI control

Amount reduced

Capital Charge

Fixed O\&M

Variable Operating Cost

Total Cost

\section{Emissions Control Data}

Levelized Cost of Power

Factor

0.160

1.314

1.314

Units
MWe
$10^{9} \mathrm{kWhr} / \mathrm{yr}$
$\%$
$\mathrm{yr}$
tons/yr
$\mathrm{wt} \%$

Value

300

1.71

65

15

683,280

3.0

$\begin{array}{cc}\text { Units } & \mathrm{SO}_{2} \\ \% & 45 \\ \mathrm{lb} / 10^{6} \mathrm{Btu} & 1.20 \\ \mathrm{lb} / 10^{6} \mathrm{Btu} & 4.80 \\ \mathrm{lb} / 10^{6} \mathrm{Btu} & 2.64 \\ \text { tons } / \mathrm{yr} & 18,654\end{array}$

Current Dollars

Constant Dollars

Mills/kWhr

Factor

Mills/kWhr

0.36

0.124

0.28

0.19

1.000

0.14

6.44

1.000

4.90

6.98

5.32

\section{Levelized Cost - $\mathrm{SO}_{2}$ Removal Basis}

Capital Charge
Fixed O\&M
Variable Operating Cost
Total Cost

Factor
0.160
1.314
1.314

$\$$ ton

\$/ton removed

Factor

33

0.124

removed

20

1.000

26

589

1.000

15

448

643

490

Basis: $300 \mathrm{MWe}$ unit size and $65 \%$ onstream capacity factor

$26 \%$ calcium utilization @ Ca/S ratio of 1.75 and $\$ 83 /$ ton price for $95 \% \mathrm{Ca}(\mathrm{OH}) 2$ hydrated lime 
TABLE 4. SI COMPARISON WITH OTHER $\mathrm{SO}_{2}$ COMPLIANCE OPTIONS

\begin{tabular}{||l|c|c||}
\hline \multicolumn{1}{|c|}{ Technology } & $\begin{array}{c}\mathrm{SO}_{2} \text { Removed } \\
\%\end{array}$ & $\begin{array}{c}\mathrm{SO}_{2} \text { Removed } \\
\$ / \text { ton }\end{array}$ \\
\hline $\mathrm{SI}$ & $30-50$ & $490^{1}$ \\
\hline $\mathrm{SO}_{2}$ Scrubbers & $90-95$ & $322^{2}$ \\
\hline Switch to Low Sulfur Coal & $65-85$ & $113^{3}$ \\
\hline $\mathrm{SO}_{2}$ Allowance Credits & $0-100$ & $110^{4}$ \\
\hline
\end{tabular}

(1) Nominal cost for 300 MWe unit based on $26 \%$ calcium utilization and hydrated lime at $\$ 83 /$ ton

(2) Power Generation publication, 4/4/97, based on average cost for 80 scrubbers (1996 survey)

(3) Power Generation publication, 4/4/97, average of 112 units that switched to low sulfur Western coal

(4) Power Generation publication, 4/4/97, average selling price in 1996

With current economics, the SI technology will probably not be cost competitive with other available utility options for base and intermediate load unit applications unless the SI calcium utilization can be increased and the cost of the lime based reagent decreased. 


\subsection{OVERVIEW}

\subsection{Purpose of the Report}

The purpose of the Guideline Manual is to provide recommendations for the application of combined gas reburning-sorbent injection (GR-SI) technologies to pre-NSPS boilers. The manual includes design recommendations, performance predictions, economic projections and comparisons with competing technologies. The report also includes an assessment of boiler impacts.

\subsection{Basis of the Report}

Two full-scale demonstrations conducted as a part of the U.S. Department of Energy's Clean Coal Technology Program (Round 1) form the basis of the Guideline Manual. The purpose of the demonstrations was to assess the air emissions reduction potential of GR$\mathrm{SI}$ on coal-fired utility boilers. The targeted emissions are those that comprise acid rain precursors, specifically oxides of nitrogen $\left(\mathrm{NO}_{x}\right)$ and sulfur dioxide $\left(\mathrm{SO}_{2}\right)$. The specific performance goals were to demonstrate $\mathrm{NO}_{x}$ and $\mathrm{SO}_{2}$ emission reductions of $60 \%$ and $50 \%$, respectively with acceptable unit operability and minimal operating cost. The emission reduction goals for both demonstrations were achieved, showing that the design methodology developed and applied by EER was valid.

The first demonstration was performed at Illinois Power's Hennepin Unit \#1, located in Hennepin, Illinois. This unit is a $71 \mathrm{MWe}$ (net) tangentially-fired boiler that fires high-sulfur Illinois coal. The second demonstration was performed at City Water Light \& Power's Lakeside Unit \#7, located in Springfield, Illinois. This unit is a $33 \mathrm{MWe}$ (gross) cyclonefired boiler that also fires high-sulfur Illinois coal. 
Following design and installation of the equipment, the optimum operational setpoints were established through a series of pre-planned parametric tests. Optimum conditions are defined as those providing the maximum benefit (reductions of $\mathrm{NO}_{x}$ and $\mathrm{SO}_{2}$ emissions) for the minimum cost (natural gas usage) while operating within established boiler constraints. The parametric tests were followed by normal operation for approximately one year. Both prior to and following the long-term tests, a series of inspections were performed to assess the durability of the boiler tubes and other boiler equipment.

\subsection{Reference Material}

For a detailed technical description of the two GR-SI projects described above, please refer to the following reports:

Enhancing the Use of Coals by Gas Reburning-Sorbent Injection

Volume 1 - Program Overview

Volume 4 - Gas Reburning-Sorbent Injection at Lakeside Unit 7, City Water Light and Power, Springfield, Illinois

Prepared under:

U.S. Department of Energy Cooperative Agreement DE-FC22-87PC79796 Gas Research Institute Contract No. 5087-254-149

Illinois Department of Commerce and Community Affairs

Prepared by:

Energy and Environmental Research Corporation

For additional information, please refer to the technical papers listed in the references and the technical reports listed in the bibliography of this report. 


\subsection{PROCESS DESIGN}

\subsection{Process Description}

\subsubsection{Gas Reburning}

Gas Reburning (GR) is a very flexible NOx reduction technology that can be run in several ways to provide varying degrees of NOx reduction. The GR system can be operated under the three following conditions:

\subsubsection{Baseline mode with no reburn fuel}

Under this condition, although no reburn fuel is being added, there are low rates of cooling air flowing around the gas injectors and through the overfire ports. Based on maintaining the same oxygen level in the flue gas exiting the furnace as for the pre-GR application, a slight air staging occurs that reduces NOx emissions slightly ( $10 \%$ reduction) compared to pre-GR retro-fit emissions. Carbon burnout under this mode of operation will be very similar to the pre-GR retro-fit.

\subsubsection{Overfire air (OFA) only}

By adding overfire air without the use of reburn fuel, staged combustion can be put into place to reduce NOx emissions. In this mode of operation, as the overfire air rate is increased, the air rate to the primary burners automatically decreases to maintain the $\mathrm{O}_{2}$ set point at the exit of the boiler economizer.

With a reduced air rate to the burners, the localized burner zone becomes hotter which has the tendency to increase NOx production under oxidizing conditions, but since there is less fuel being fired through the burners a greater percentage of heat is absorbed in the furnace 
walls that would cool the burner zone. Even if the localized temperatures increase, the temperature mechanism for increasing NOx emissions is more than offset by the reduced partial pressure of the oxygen in the burner zone. The lower the partial pressure of oxygen, the lower the NOx production, and in the burner zone the oxygen concentration is controlling.

With this type of staged combustion approach, overfire air is added at a point downstream of the burners where the flue gas is cool enough to minimize the production of thermal NOx. With deeper staging (lowering of excess air levels in the primary burner zone) NOx emissions will reduce. The degree of staging is partially limited by the potential for higher corrosion in the hot burner zone due to higher $\mathrm{CO}$ concentrations, the deeper the staging the greater the potential for corrosion.

The other limiting factor is the carbon in the fly ash which increases with deeper staging. High carbon in ash could affect the ability of the utility to sell its fly ash to the cement industry. Overall NOx reduction using a near optimum overfire air addition rate, taking into consideration the concerns delineated above, will yield approximately a $35 \%$ reduction compared to pre-GR retrofit operation.

\subsubsection{Reburn mode}

Under full GR implementation, the combustion process is divided into three zones as illustrated in Figure 2-1. In the primary zone, the main fuel is fired through conventional burners but at a reduced rate to compensate for the reburning fuel which is injected downstream.

In the reburning zone, injection of the reburning fuel consumes the excess air (oxygen) from the primary zone, producing a slightly fuel rich region where NOx is reduced by reactions with hydrocarbon radicals, carbon monoxide and hydrogen. Flue gas 


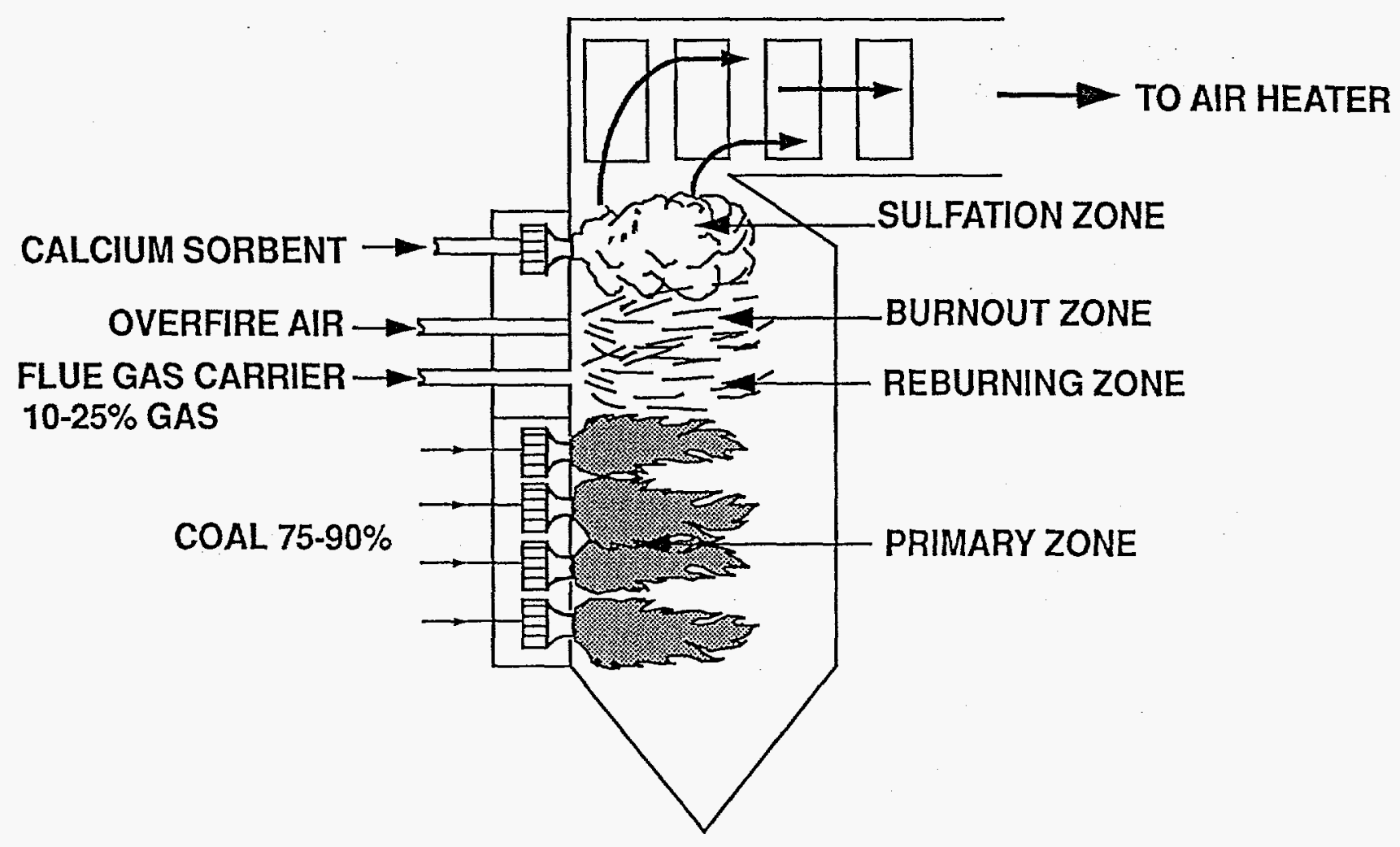

Figure 2-1. Schematic of GR-SI System 
recirculation (FGR) may be used to provide momentum to the natural gas injection. FGR has a low $\mathrm{O}_{2}$ content and therefore has a minor impact on reburning and burnout zone stoichiometric ratios. OFA is added in the burnout zone to complete the combustion of the fuel gases produced in the reburning zone and to adjust the overall excess air to yield good carbon burnout. Thus, except for relatively minor changes in boiler efficiency, the total heat input to the furnace is the same as baseline operation, but is divided into two fuel streams. Similarly, the total air supplied to the furnace remains essentially unchanged but is divided into two streams, supplying air to the conventional burners and also to the OFA ports.

The three zones are described in more detail as follows:

- $\quad$ Primary (burner) Zone: Coal is fired at a rate corresponding to 75 to 90 percent of the total heat input, under low excess air ( $S R=1.05$ to 1.15). $\mathrm{NO}_{x}$ emissions in this zone are reduced by the lower heat release and the reduced oxygen concentrations.

- Reburn Zone: Reburn fuel (natural gas in this case) injection creates a fuel rich region wherein hydrocarbon fragments $\left(\mathrm{CH}, \mathrm{CH}_{2}\right.$, etc.) and carbon monoxide and hydrogen are formed which react with $\mathrm{NO}_{x}$, reducing it to atmospheric nitrogen. The optimum reburning zone stoichiometric ratio is approximately 0.90 , achieved by injecting natural gas at a rate corresponding to about 15 to 20 percent of the total heat input. FGR may be injected with the natural gas to provide for better penetration and mixing with the furnace flue gas.

- Burnout (exit) Zone: OFA is injected higher up in the furnace to complete the combustion. OFA is typically 20 percent of the total air flow; a minimum excess air of 15 percent in maintained. OFA injection is optimized to minimize $\mathrm{CO}$ emissions and unburned carbon-in-fly ash.

With the GR system, natural gas is routed to the reburning zone of the boiler and introduced into the boiler gas stream through a series of injection nozzles. The flow rate of gas to the reburn injectors is controlled automatically by the boiler operation control 
system. FGR, if used, is extracted from the boiler backpass, enhanced by a booster fan and injected simultaneously with the natural gas. To complete the fuel combustion, air at 500 to $600^{\circ} \mathrm{F}$ is extracted from the secondary air duct or windbox and is injected into the boiler downstream of the reburning zone through a series of OFA injection nozzles (see Figure 2-2). With GR, depending on initial NOx concentrations and reburn zone residence time, NOx reductions of 60 to $75 \%$ may be achieved.

A minimal flow of hot secondary air is maintained though the OFA injection nozzles when the GR system is not in service to keep the OFA nozzles cool and ambient air is used to cool the gas injection nozzles.

\subsubsection{Sorbent Injection}

Sorbent Injection (SI) technology controls $\mathrm{SO}_{2}$ emissions through injection of a calciumbased sorbent such as hydrated lime $\left[\mathrm{Ca}\left(\mathrm{OH}_{2}\right)\right]$ into the boiler furnace under the proper temperature condition where it reacts with gaseous $\mathrm{SO}_{2}$ to form solid calcium sulfate (see Figure 2-2).

Due to the high furnace temperature the injected hydrated lime is quickly calcined into calcium oxide $\left[\mathrm{Ca}(\mathrm{OH})_{2}+\right.$ heat $\left.\rightarrow \mathrm{CaO}+\mathrm{H}_{2} \mathrm{O}\right]$. A portion of the calcium oxide then reacts

with sulfur dioxide and oxygen in the furnace flue gases [ $\left.\mathrm{CaO}+\mathrm{SO}_{2}+1 / 2 \mathrm{O}_{2} \rightarrow \mathrm{CaSO}_{4}\right]$ forming calcium sulfate (gypsum). The partially sulfated sorbent material then passes through the boiler convective pass with the flue gas to be eventually collected by the particulate control device. Calcium oxide reactivity and residence time under sulfation conditions are the two major parameters which control utilization of the calcium of the sorbent and thus the cost effectiveness of the process. Calcium oxide reactivity depends strongly on its porosity and particle size as well as its thermal history. At a point, reactivity tends to decrease with increases in sorbent particle temperature due to grain growth. The 

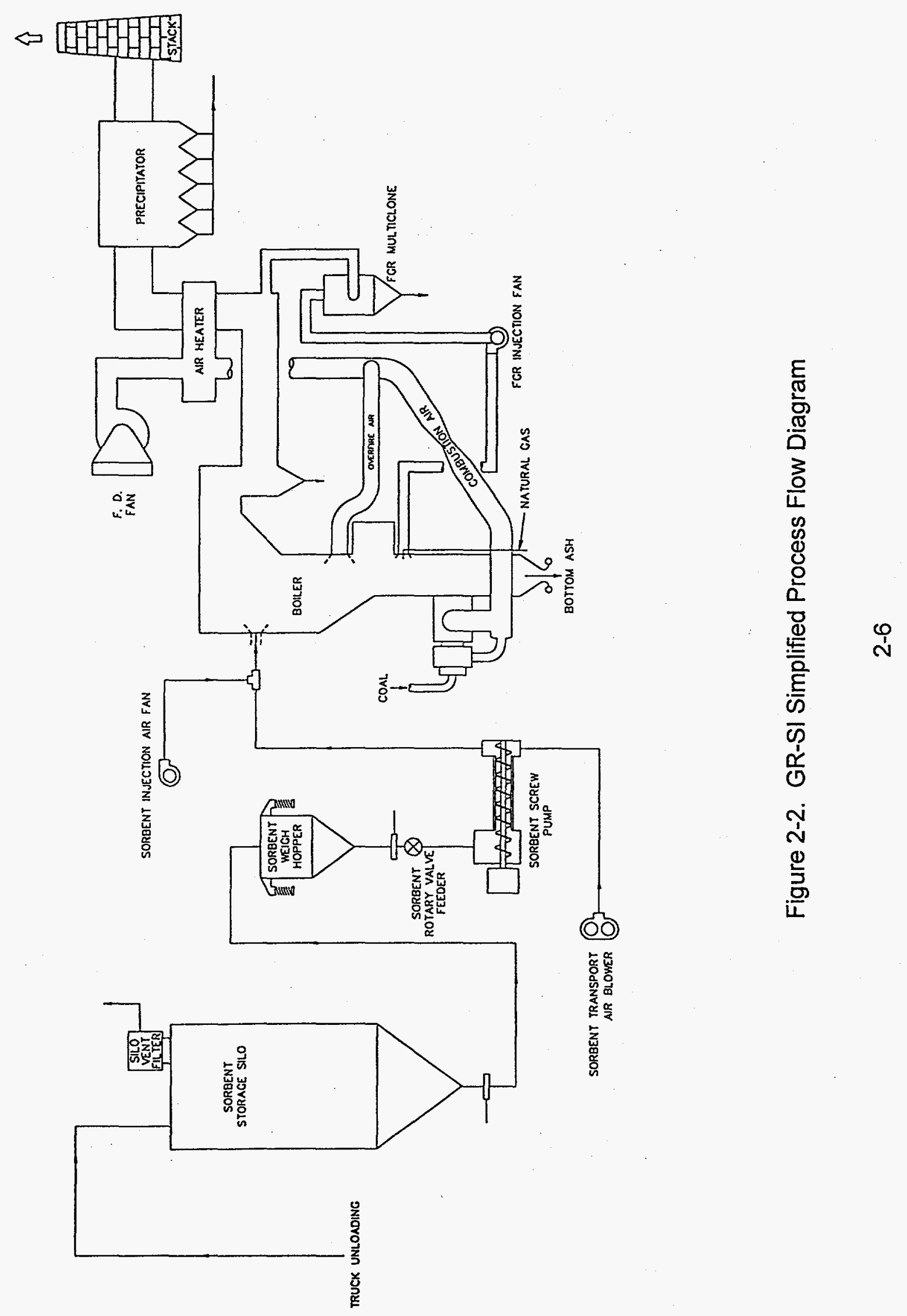
residence time of the calcined sorbent particle in an optimum temperature window has a significant impact on sulfur (dioxide) capture potential.

Significant sulfation cannot occur above approximately $2250^{\circ} \mathrm{F}$ since the surface of the sorbent particle will be sintered (dead burned) to thwart the gas-solid reactions from occurring. Further, at these temperatures the calcium sulfate will start to decompose back to calcium oxide and sulfur dioxide. With a fluidized bed combustor the optimum temperature for lime based sorbent capture of sulfur dioxide is 1500 to $1600^{\circ} \mathrm{F}$. However, with furnace injection sulfation becomes negligible below approximately $1600^{\circ} \mathrm{F}$, due to the reaction rate requirements for the relatively short residence times in the furnace.

Sorbent is transported from a storage silo to the boiler and introduced into the flue gas through injection nozzles. A flow splitter in the sorbent line equally distributes the sorbent to the nozzles. To obtain the optimum sorbent mass flow and nozzle velocities required for adequate boiler dispersion, additional injection air is provided from a booster fan. Ambient air is used to cool the nozzles when the sorbent system is not in operation.

\subsection{3 $\quad$ GR-SI Integration}

GR and $\mathrm{SI}$ are applied simultaneously to achieve combined $\mathrm{NO}_{x}$ and $\mathrm{SO}_{2}$ control. Although significantly reducing the $\mathrm{NO}_{x}$ emissions, $\mathrm{GR}$ also achieves an incremental reduction in $\mathrm{SO}_{2}$ emissions, since natural gas contains no sulfur. This complements the $\mathrm{SO}_{2}$ reduction of the $\mathrm{SI}$ process and reduces the amount of sorbent otherwise required. The GR-SI system control may be integrated with any utility boiler control system. All start/modulation/stop operations may be performed in the boiler control room. 


\subsection{Process Design Guidelines}

\subsubsection{Gas Reburning}

Since reburning requires no physical changes to the main combustion system, it can be applied to furnaces with virtually any firing configuration and fuel. The reburning process can be applied to all types of firing equipment including cyclone, tangential, wall, and stoker coal fired boilers. In addition, reburning can be applied to furnaces fired with any fossil fuel (coal, oil, gas, etc...). Reburning can also be applied to municipal waste incinerators, industrial boilers, and a range of industrial process furnaces.

The variables to be considered for an effective retro-fit of a GR system to an existing utility boiler are many, see Table 2-1. First of all, baseline NOx must be determined and the desired level of NOx reduction must be set. An evaluation must be made concerning the boiler configuration as input into determining the available residence times for the Reburn and OFA zones. A detailed boiler inspection is required to determine any physical constraints imposed regarding the locations of the gas reburn piping, OFA ducting, and reburn and OFA injectors.

\subsubsection{Primary Zone}

The burners in the primary zone do not require any modifications. However, by replacing excess air burners with low $\mathrm{NO}_{x}$ burners, $\mathrm{NO}_{x}$ reduction will be enhanced. The burners should be operated in a balanced mode and with the lowest excess air commensurate with acceptable lower furnace performance considering flame stability, carbon in ash, flame impingement and waterwall corrosion. Typically the optimum air for burner operation with GR is a rate that provides for about a $10 \%$ excess air condition in the primary zone. 
TABLE-2-1. GR DESIGN GUIDELINES

\begin{tabular}{|c|c|c|c|}
\hline Parameter & Units & Value & Comments \\
\hline Primary Stoichiometry & SR & $\sim 1.10$ & $\begin{array}{l}\text { As low as possible } \\
\text { commensurate with good } \\
\text { lower furnace performance } \\
\text { and good carbon burnout }\end{array}$ \\
\hline $\begin{array}{l}\text { Reburn Injector } \\
\text { Vertical Location }\end{array}$ & NA & $\begin{array}{l}\text { Maximum temperature zone } \\
\text { above burners }\end{array}$ & $\begin{array}{l}\text { Primary burner fuel } \\
\text { combustion must be } \\
\text { essentially complete }\end{array}$ \\
\hline Reburn gas flow & $\begin{array}{l}\% \text { of total } \\
\text { heat input }\end{array}$ & $\sim 18$ & $\begin{array}{l}\text { Design for a maximum of } \\
25 \% \text { for flexibility }\end{array}$ \\
\hline $\begin{array}{l}\text { Reburn zone } \\
\text { Stoichiometry }\end{array}$ & SR & $\sim 0.90$ & $\begin{array}{l}\text { Varies with gas injection } \\
\text { rate to control } \mathrm{NO}_{\mathrm{x}} \text { and } \\
\text { primary burner zone SR. }\end{array}$ \\
\hline Reburn injector array & NA & $\begin{array}{l}\text { Rapid and complete mixing } \\
\text { across furnace cross section }\end{array}$ & Site specific design \\
\hline $\begin{array}{l}\text { Reburn gas } \\
\text { carrier fluid }\end{array}$ & NA & $\begin{array}{l}\text { Flue gas recirculation (FGR) } \\
\text { is preferred }\end{array}$ & $\begin{array}{l}\text { Carrier gas with zero } \\
\text { oxygen is the best, FGR, } \\
\text { low in } \mathrm{O}_{2} \text { is the most cost } \\
\text { effective }\end{array}$ \\
\hline $\begin{array}{l}\text { Reburn zone } \\
\text { residence time }\end{array}$ & Sec. & $\begin{array}{l}0.25 \text { minimum } \\
0.50 \text { and up is best }\end{array}$ & $\begin{array}{l}\text { Above } 0.50 \text { sec., FGR may } \\
\text { not be required }\end{array}$ \\
\hline $\begin{array}{c}\text { Overfire air } \\
\text { (OFA) vertical position }\end{array}$ & NA & $\begin{array}{l}\text { Located as high in the } \\
\text { furnace as possible with } \\
\text { complete combustion prior to } \\
\text { convective pass entry }\end{array}$ & Site specific design \\
\hline $\begin{array}{c}\text { Overfire air } \\
\text { (OFA) injector array }\end{array}$ & NA & $\begin{array}{l}\text { Rapid and complete mixing } \\
\text { across the furnace cross } \\
\text { section }\end{array}$ & Site specific design \\
\hline $\begin{array}{l}\text { Overfire air } \\
\text { (OFA) zone }\end{array}$ & SR & 1.15 to 1.20 & $\begin{array}{l}\text { Sufficient to achieve } \\
\text { baseline flue gas } \mathrm{O}_{2} \\
\text { May be adjusted to affect } \\
\text { carbon burnout }\end{array}$ \\
\hline
\end{tabular}


Ventical location The reburn fuel injectors should be located above the uppermost row of burners. Optimum performance is achieved by positioning the injectors at the highest possible temperature (which means a location closest to the burners) where the burner fuel combustion is essentially complete. This point can be established by field testing using infurnace measurements to establish $\mathrm{O}_{2}, \mathrm{CO}$ and carbon in ash augmented by visual flame inspection through available ports. Optionally, or in addition to this empirical approach, the burner flame zones can be analytically modeled. It may also be necessary to make some adjustments to the vertical location of the injectors to avoid buckstays, platforms or other interferences external to the boiler.

Rate of Reburn Fuel Injection It is assumed that the objective of each utility, based on economics will be to achieve the maximum possible $\mathrm{NO}_{\mathrm{x}}$ reduction with the least amount of gas reburn fuel. The optimum condition for achieving this typically occurs when the rate of reburn fuel is set to yield about a 0.90 stoichiometric air/fuel ratio in the reburn zone. Based on the $10 \%$ excess air example for the primary zone, a $90 \%$ theoretical air in the reburn zone will require a reburn fuel rate that provides about $18 \%$ of the total boiler fuel input. To provide a margin of comfort regarding the optimum rate, the system should be designed to handle somewhat more gas flow, say $25 \%$. It should be recognized that the gas flow rate is a variable and will be adjusted during operation as $\mathrm{NO}_{\mathrm{x}}$ control needs vary, higher gas rates yield higher NOx reductions and vice versa.

Gas Injector Array Once the vertical position for the gas injectors has been established, the injector array can be designed. The injectors must be designed to achieve uniform and complete mixing of the reburn gas across the full boiler cross section. The rate of mixing should be accomplished in minimum time so as to the maximize reburn zone residence time. The variables to adjust to achieve this include the number and position of reburn injectors and injection design parameters (mass flow rate of gas and any carrier gas, 
injection velocity and injection angle). A number of analytical and empirical techniques, see Section 2.3, are used to design the injector array.

Carrier Gas A carrier gas, such as FGR, in certain applications can help to maximize the NOx reductions of a GR system. The carrier gas is used to increase the penetration and rate of mixing of the natural gas throughout the reburn zone. A carrier gas could be required to provide adequate penetration in large furnace boxes or for applications where the reburn zone residence times are short $(<0.50 \mathrm{sec}$.).

The carrier gas has the following impacts on reburning:

- $\quad$ Provides rapid and effective mixing, the momentum of the injected gas can be enhanced by injecting the gas along with a carrier medium.

- Oxygen in the carrier medium is deleterious to reburn performance. The reason is that optimum $\mathrm{NO}_{x}$ reduction is achieved under fuel rich conditions. As oxygen is added to the reburn zone via the carrier gas, additional reburn gas must be injected to consume this oxygen. This can result in a significant increase in the amount of natural gas required to achieve a specific $\mathrm{NO}_{\mathrm{x}}$ emissions level. Since the natural gas cost is the most significant component of the operating cost, this has the potential to adversely affect economics. Three carrier mediums can be considered: air, steam and flue gas. Air has $21 \% \mathrm{O}_{2}$ and therefore is a poor choice based on gas consumption. Similarly a reburn injector, configured as a burner with air injected along with the fuel, requires more gas. Steam doesn't introduce $\mathrm{O}_{2}$; however, it has to be produced which requires both energy and water treatment. Flue gas is typically the best carrier medium. It has low $\mathrm{O}_{2}$ (typically $3 \%$ ) and requires no energy to produce. It does require a dust collector, fan and duct work. In this CCT-1 project, EER used FGR as a carrier gas. In the CCT-3 project, EER developed a second generation approach whereby the carrier requirement was eliminated (see CCT-3 report).

- Provides the advantage of being able to control injection parameters independent of the natural gas flow. Typically, the FGR carrier flow rate significantly exceeds the gas flow rate. Therefore as the gas flow rate varies, the injection velocity and flow rate are nearly constant. This allows for good mixing of the reburn fuel with the furnace gases as the natural gas flow is 
turned down.- Alternately, by varying the carrier medium flow, mixing conditions can be adjusted independent of the gas injection rate. This provides operational flexibility.

Reburn Zone Residence Time This refers to the time of passage of combustion products flowing through the reburn zone from the point of gas injection to the point of overfire air injection. The $\mathrm{NO}_{\mathrm{x}}$ reduction reactions occur rapidly. Once the gas has been mixed with the flue gas, most of the $\mathrm{NO}_{\mathrm{x}}$ reduction occurs within 100 milliseconds. Longer residence times result in additional $\mathrm{NO}_{\mathrm{x}}$ reduction. Allowing for mixing times, a residence time on the order of 0.25 seconds is adequate to achieve good performance. A residence time of 0.50 seconds and greater provides excellent performance. EER uses a $\mathrm{NO}_{x}$ model to calculate the $\mathrm{NO}_{\mathrm{x}}$ reduction for a specific application. It is applied considering the finite mixing rates. It should be noted that in some boilers there is significant flow separation. For example in the cyclone unit tested in this program at CWLP, a large recirculation region was present in the upper furnace. The residence time of concern for reburning is the residence time passing through the non-separated region.

\subsubsection{Overfire Air}

Vertical Position The vertical position of the overfire air ports is established by balancing the need to maximize reburn zone residence time (which suggests ports higher in the furnace) and the need to ensure complete combustion prior to the convective pass (which suggests ports lower in the furnace). An oxidation model is applied to evaluate the conditions necessary to essentially complete combustion prior to the convective pass.

Rate of Overfire Air The overfire air injection rate should be sufficient to raise the stoichiometry of the combustion products to an excess air condition typical of baseline operation $\left(\sim 3-4 \%\right.$ excess $\left.\mathrm{O}_{2}\right)$. It should be noted that in a conventional single stage combustion system, the overall excess air is the same as the burner excess air. In such a system, the operating excess air is established by the operators considering its impact 
on burner performance, ash deposition in the lower and upper furnace, steam temperature and carbon burnout.

In a reburning system, the burner performance is de-coupled from the overall excess air. This provides the boiler operators with enhanced flexibility to adjust overfire air. By designing an overfire air system for rapid and complete mixing, it may be possible to operate the unit at excess air levels lower than baseline while still achieving good carbon burnout.

Overfire Air Injector Array Once the vertical position has been established, the overfire air injector array can be designed. The overfire air injector performance impacts carbon burnout and more specifically the minimum excess $\mathrm{O}_{2}$ necessary to achieve burnout. The overfire air injectors must be designed to achieve uniform and complete mixing of the overfire air across the full boiler cross section in minimum time. The variables to adjust to achieve this include the number and position of the overfire air injectors, and injection parameters (injection velocity and injection angle). A number of analytical and empirical techniques can be used to design the injector array as indicated in Section 2.3.

\subsubsection{Sorbent Injection}

Like GR for $\mathrm{NOx}$ control, $\mathrm{SI}$ for $\mathrm{SO}_{2}$ control may also be applied to any type of coal-fired utility boiler; including cyclone, tangential, wall, and stoker fired units. However, certain variables must be considered when evaluating the retro-fit of an SI system to a specific utility boiler, see Table 2-2.

The $\mathrm{SO}_{2}$ reduction potential of the $\mathrm{SI}$ technology is limited and best applies to those units that require modest levels of $\mathrm{SO}_{2}$ reductions. The higher the $\mathrm{SO}_{2}$ removal desired, the higher the $\mathrm{Ca} / \mathrm{S}$ ratio must be to achieve such reductions and the lower the sorbent calcium utilization. Lower calcium utilization in combination with the need for added sootblowing 
TABLE-2-2. SI DESIGN GUIDELINES

\begin{tabular}{|c|c|c|c|}
\hline Parameter & Units & Value & Comments \\
\hline Sorbent Type & NA & Calcium Hydroxide & Highest reactivity \\
\hline Injection Temperature & ${ }^{\circ} \mathrm{F}$ & $\sim 2200$ & $\begin{array}{l}\text { "Dead Burning" may occur at } \\
2250^{\circ} \mathrm{F} \text { and greater }\end{array}$ \\
\hline $\begin{array}{l}\text { Residence time in } \\
\text { Temp. Window }\end{array}$ & Sec. & $\sim 0.5$ & $\begin{array}{l}\text { Temperature window } \\
\text { from } 2200 \text { to } 1600^{\circ} \mathrm{F}\end{array}$ \\
\hline Sorbent injector array & NA & $\begin{array}{l}\text { Rapid and complete mixing } \\
\text { across furnace cross section }\end{array}$ & Site specific design \\
\hline Carrier Fluid & NA & Air & Can be integrated with overfire air \\
\hline Injection rate (Ca/S) & $\begin{array}{l}\text { Molar } \\
\text { Ratio }\end{array}$ & $\sim 2.0$ & $\begin{array}{l}\text { Vary to control } \mathrm{SO}_{2} \text { as required. } \\
\text { Maximum dictated by fouling }\end{array}$ \\
\hline $\begin{array}{l}\text { Maximum } \mathrm{SO}_{2} \\
\text { Control }\end{array}$ & $\%$ & $40-80$ & Site specific \\
\hline
\end{tabular}

with high $\mathrm{Ca} / \mathrm{S}$ ratios, have technical/economic effects which limit the practical maximum degree of $\mathrm{SO}_{2}$ reduction ( $\left.50 \%\right)$ with the $\mathrm{SI}$ technology.

\subsubsection{Sorbent Type}

A number of calcium based sorbents can be used; including limestone, dolomite, calcium hydroxide. The sorbents may be produced with various processes to enhance reactivity. However, it is difficult to evaluate reactivity based on sorbent properties, and in particular the surface area of the sorbent and the particle size cannot be used. When the sorbent is injected into the furnace, its characteristics are changed by the high temperature environment. For limestone and dolomite, the $\mathrm{CO}_{2}$ in the carbonate is driven off, leaving 
the oxide $\mathrm{CaO}$; this is termed calcining. For hydrated lime, the $\mathrm{H}_{2} \mathrm{O}$ is driven off leaving $\mathrm{CaO}$. The $\mathrm{CaO}$ reacts with $\mathrm{SO}_{2}$. Therefore, it is the characteristics of the "activated" $\mathrm{CaO}$ particles that affect $\mathrm{SO}_{2}$ capture. The activated $\mathrm{CaO}$ has external surface and internal pore surface areas.

The external surface area is always available for reaction with $\mathrm{SO}_{2}$. However, to utilize the pore area, $\mathrm{SO}_{2}$ must diffuse into the pores and sulfate deposits at the pore openings can restrict mass transfer to limit the usefulness of the internal surface area. Each sorbent material produces a different $\mathrm{CaO}$ reactivity (such reactivity translates to $\mathrm{SO}_{2}$ penetration into the sorbent pores). Impurities or additives in the sorbent, preparation methods, and sorbent injection conditions (primarily temperature) can all affect the reactivity of the activated $\mathrm{CaO}$. To diminish the effect of pore access on calcium utilization, everything else being equal, the smaller the sorbent particles, the higher the calcium utilization.

To evaluate sorbent reactivity, a test should be conducted using the specific sorbent. The test should duplicate the $\mathrm{SO}_{2}$ level in the furnace and the temperature history of the injected sorbent in the full scale application. The $\mathrm{SO}_{2}$ reduction should be measured well downstream of the key temperature window. The figure of merit for sorbents most commonly used is the $\mathrm{SO}_{2}$ reduction achieved at a Ca/S molar ratio of 2.0. A sorbent with good reactivity injected under optimum process conditions can typically achieve $50 \% \mathrm{SO}_{2}$ reduction from medium to high sulfur coals at $\mathrm{Ca} / \mathrm{S}=2.0$.

\subsubsection{Sorbent Injection Temperature (vertical location)}

The empirical evaluation of sorbent reactivity discussed above can also provide information on the effect of sorbent temperature history on performance. The furnace flue gas quench rate is dictated by the design of the boiler which establishes the heat absorption profile. Changes in quench rate require altering the heat exchanger surface or load/excess air changes which have costs and/or performance impacts associated with them that normally 
make quench rate change options-unacceptable. Therefore, the sorbent injection system must be optimized to match the given characteristics of the specific boiler application.

For typical convective pass quench rates, the optimum temperature for sorbent injection is about $2200^{\circ} \mathrm{F}$. Injection at higher temperatures will melt the surface of the sorbent ("dead burning") making the particle pores impervious to $\mathrm{SO}_{2}$ entry and effectively eliminating the internal surface reaction area. Injection at lower temperatures reduces the residence time available for $\mathrm{SO}_{2}$ reactions in the temperature window. With high quench rates (low volumetric heat release units), the residence time in the window is decreased. For these applications the sorbent injection location should be moved upstream to increase the sorbent residence time in the window and vice versa for those units with low quench rates (high volumetric heat release units).

It is important to note that the temperature of the furnace gases varies in three dimensions and with boiler operating conditions; load, excess air, burner settings - including tilt with tangential units, operation of the gas reburning system, and amount and condition of ash deposits in the furnace and convective pass. For optimum $\mathrm{SO}_{2}$ control, the sorbent injection must accommodate these spacial and temporal variations. Depending on the system, it may be necessary to use multiple injection elevations.

\subsubsection{Sorbent Injector Array}

Once the vertical sorbent injection location has been set, the sorbent injector array can be designed. As with the overfire air and reburn gas injector designs, the objective is to inject the sorbent into the furnace to mix it with the furnace gases rapidly and completely, thus maximizing the residence time in the temperature window.

The variables to adjust to change mixing condition include the number and position of the sorbent injectors, and injection parameters (injection velocity and injection angle). A 
number of analytical and empirical techniques can be used to design the sorbent injector array as indicated in Section 2.3.

\subsubsection{Carrier Fluid}

Any convenient carrier fluid can be used to inject the sorbent. The amount of air injected is typically a few percent of boiler flow. If the sorbent injection system is integrated with a gas reburning system, and the overfire air is injected at a temperature commensurate with good sorbent performance $\left(2200^{\circ} \mathrm{F}\right)$, then the sorbent injectors can be integrated with the overfire air ports. This provides some reduction in system complexity and cost.

\subsubsection{Maximum $\mathrm{SO}_{2}$ Control}

The maximum $\mathrm{SO}_{2}$ control achievable by sorbent injection is site specific and is related to the impacts of the injected sorbent on ash deposition and dust collection. For sorbent injection alone, the total dust loading passing through the furnace is the sum of the coal ash and the spent sorbent. With gas reburning-sorbent injection, the coal flow rate is reduced to accommodate the gas with attendant reduction in the coal ash passing through the furnace. Thus, for small sorbent injection rates, the total dust loading with GR-SI could be less than baseline. However, as the sorbent injection flow rate is increased, the total dust loading increases and at a design point of $\mathrm{Ca} / \mathrm{S}=2.0$, the total dust loading is increased from baseline substantially. This can be easily calculated from the flow rates of coal ash and sorbent entering the furnace. Baseline data can be used to estimate the fraction of the coal ash which is carried over as flyash. To be conservative it should be assumed that all of the sorbent is blown out of the furnace with the flyash. The primary limiting factors for the SI technology are (1) ash deposition and (2) dust collection. They are discussed below. 
The sorbent is typically injected high in the furnace and therefore has little impact on ash deposition and heat transfer in the lower furnace. In the upper furnace and convective pass the sorbent adds to the flue gas dust loading. The sorbent deposits generally have lower radiant energy absorption (more reflective deposits) than coal ash deposits and this reduces radiation heat transfer. Also, the increased dust loading results in increased deposition rates, particularly in the high temperature sections of the convective pass. As the sorbent injection rate is ramped up from zero, initially these impacts are minor and can be accommodated by slight shifts in burner tilts (with tangential units) and attemperation flow rates and increased sootblowing frequency. However, as the sorbent injection rate is increased further, the fouling and heat transfer shifts become unacceptable and effectively limit the maximum sorbent injection rate.

\subsubsection{Dust Collection}

The particulate exiting the boiler is captured in a downstream dust collector, typically an electrostatic precipitator (ESP) or a fabric filter. Both boilers retrofitted with the GR-SI systems in this project had cold-side electrostatic precipitators.

Sorbent injection has two adverse effects on dust collection: increased dust loading and increased dust resistivity. If the collection efficiency of the ESP remains constant, the dust emissions from the system will be proportional to the dust loading entering the ESP. Since any increase in dust emissions is usually unacceptable, the collection efficiency of the ESP must be enhanced. The collection efficiency of an ESP depends on a number of factors and analytical models are available for predicting performance. One important parameter is the resistivity of the flyash that establishes the voltage gradient through the ash deposits on the precipitator plates. This in turn controls the maximum current that can be applied without "spark-over". High resistivity flyash decreases the maximum current and thus 
reduces dust collection efficiency. Calcium sorbents, because they react with the $\mathrm{SO}_{3}{ }^{=}$(a gas that reduces the fly ash resistivity) exiting the furnace produces a high resistivity flyash which degrades precipitator collection efficiency, thus compounding the dust emission problem. One way to counter this effect is to cool the flue gas upstream of the ESP. In this project humidification (liquid water injection) was used effectively.

These combined effects typically limit the maximum sorbent injection rate for medium to high sulfur coals to the range of $\mathrm{Ca} / \mathrm{S}=2.0$. Thus, the maximum $\mathrm{SO}_{2}$ control depends on sorbent reactivity which is established for the specific sorbent and application in bench scale combustion tests.

\subsection{Process Design Tools}

The application of the GR-SI technology is developed according to a design methodology that involves the application of various experimental and analytical tools. Bench and pilot scale studies, as well as full scale demonstrations, have established that the major process parameters controlling the effectiveness of the reburning process are the operating stoichiometric ratio (air/fuel), temperature, and residence time and distribution of the reactants in the reburning zone. Pilot-scale studies have also shown the importance of effective mixing in both the reburning and burn out zones. In utility boilers with relatively short upper furnace residence times, mixing rates of the reburning gas and OFA largely control the effectiveness of the process. The following tools are used in the design of the GR-SI system.

\subsubsection{Isothermal Flow Modeling}

Rapid and complete mixing of the injected reactants with the local furnace gases is of critical importance in the successful application of the GR-SI process. Detailed information concerning the flow field of the subject boiler can be accomplished by isothermal flow 
modeling. EER has successfulty-used $1 / 12$ scale boiler models to evaluate the flow field using the experimental techniques of flow visualization, velocity measurements, and dispersion measurements. Models are scaled geometrically with convective pass sections designed to match full-scale pressure loss coefficients. The model burners are designed to match full-scale momentum flux ratios, and flow rates are adjusted to match the largescale flow patterns. The model is calibrated against actual furnace gas directional velocity measurements.

\subsubsection{Flow Visualization}

Using the $1 / 12$ scale model, visualization of flow fields within the boiler furnace is accomplished using smoke and neutrally buoyant bubble injection. The model is constructed of transparent plastic, allowing the visualization of the flow fields to be preserved by photographs of the smoke and bubble trajectories. Due to the high mixing rates and large flow volumes, smoke injection does not lend itself well to mapping the flow fields of individual burners. However, smoke injection is used to conveniently visualize the flow pattern and trajectory of a particular natural gas, OFA, or SI system. Neutrally buoyant bubble injection is useful in tracking the flow fields of individual burners or burner rows. The bubbles are generated by a machine that suspends helium filled soap bubbles in a flowing air stream. Bubbles are then directed through a particular burner via a tube inserted through the side of the model's burner windbox.

\subsubsection{Velocity Measurements}

Velocity measurements are made within the model using hot wire anemometer and Kurtz probe instrumentation. The Kurtz probe is an air velocity meter providing real time analog readings of air velocities and is used for rough measurements of burner velocities and checking uniformity of velocities between injectors. Tufts of yarn are used within the model to provide relative directions of flow fields. 
The hot wire anemometer is used with observations of the yarn tufts to produce velocity and mass distribution profiles at various measurement planes in the model. The velocity information provided by the hot wire anemometer is collected and processed by computer. The hot wire anemometry data and the tuft observations are used to calculate velocity components and mass fraction profiles for sample data points throughout the furnace (model). The velocity profiles are used for characterization of the model flow fields and comparison (calibration) against actual velocity measurements made on the full-scale boiler. The mass fraction profiles are used in conjunction with corresponding dispersion measurements (described below) to give sulfur capture predictions for SI configurations to be tested by the model.

\subsubsection{Dispersion Measurements}

Dispersion measurements are made to determine the degree of mixing at locations downstream of a proposed natural gas, OFA, or SI configuration. To perform the measurements, the air supplied to the proposed injection configuration is seeded with a gas (typically methane) whose concentration is readily measurable. Injection of the gas is located in a position well upstream of the injection system windbox so that complete mixing occurs prior to distribution to the various injection nozzles. A primary probe is inserted into the model at the sample point of interest, and a secondary or reference probe is inserted in the exhaust duct of the model where the gas is assumed to be well mixed with the air. Concentration profiles are then normalized for comparison of the penetration and mixing performance of the proposed injection system configurations.

\subsubsection{Overall NOx Reduction Model}

The current approach used for the modeling of $\mathrm{NO}_{x}$ formation is a compromise between semi-empirical and fully predictive models. In this approach, a boiler heat transfer model and a two-phase modular model are coupled for reburning $\mathrm{NO}_{x}$ predictions. The heat 
transfer model is used to calculate mean time-temperature profiles for the boiler, based on actual operating conditions. Information on flue gas temperature and residence time is then used in the modular model for reaction kinetics calculations. In setting up the modular model, distinctive zones in the boiler are identified and represented by combinations of Well Stirred Reactors (WSR) and Plug Flow Reactors (PFR). The PFR allows for the injection of side streams so that the reburn fuel and the OFA injection can be simulated. The modular model also incorporates a detailed submodel describing coal devolatilization, fuel nitrogen conversion, and char combustion.

For many situations, a detailed chemical kinetics model is not absolutely essential for boiler $\mathrm{NO}_{x}$ modeling. For $\mathrm{GR}$, however, detailed chemistry models become essential for two main reasons: (1) NO reduction in the reburn zone is accomplished by fuel fragments such as $\mathrm{CH}$; simpler models that do not consider such chemistry cannot be applied; and (2) a coal chemistry submodel is required to provide information on the composition of the species pool exiting the burner zone and to define initial conditions for the reburn zone $\mathrm{NO}_{x}$ calculations. Without this submodel, the reburning model becomes less effective because $\mathrm{NO}_{x}$ and other intermediate species generated in the burner zone remain unknown.

A two-phase modular model is set up around a specified number of WSR and PFR reactors connected in series. The PFR reactors allow for the injection of side streams with user specified stream composition, temperature, and injection mass flow rates. The model has a kinetics package that consists of elementary reaction mechanisms up to $\mathrm{C}_{2}$ chemistry. The package in its current form considers 60 species and 209 reactions. Certain of these species have been used specifically for describing the kinetics of coal devolatilization and combustion. In addition, gas phase species important for $\mathrm{NO}_{\mathrm{x}}$ formation and destruction, such as $\mathrm{NO}_{3}, \mathrm{HCN}, \mathrm{NO}_{x}$, and $\mathrm{N}_{2} \mathrm{O}$ are all included.

The modular model also incorporates a detailed devolatilization submodel. Coal is assumed to devolatilize into light volatiles, volatile nitrogen, and tar according to first-order 
rate equations. The remaining-solid phase material contains ash and char, which also contains residual fuel nitrogen (or char-nitrogen). The devolatilization model assumes, as suggested by experimental data, that volatile nitrogen is $\mathrm{HCN}$, and the small amount of $\mathrm{NH}_{3}$ is neglected. The aliphatic species contained in the light volatiles are made up of $\mathrm{CH}_{4}$, $\mathrm{C}_{2} \mathrm{H}_{2}, \mathrm{C}_{2} \mathrm{H}_{4}, \mathrm{H}_{2}$, and soot. Tar is assumed to have the same composition as the parent coal, based on the resemblance of IR spectra between the parent coal and the tar (Solomon and Colket, 1979). Devolatilization rate constants and partitioning of light volatiles, tar, and fuel nitrogen are based on experimental data (Kobayashi et. al., 1977; and Pohl and Sarofim, 1977; Suuberg, et. al., 1979).

The modular model includes reaction mechanisms for char oxidation and gasification. Char reacts with $\mathrm{O}_{2}, \mathrm{CO}_{2}$, and $\mathrm{H}_{2} \mathrm{O}$ to form $\mathrm{CO}_{2}, \mathrm{CO}$ and $\mathrm{H}_{2}$. Conversion of the charnitrogen into $\mathrm{N}_{2}$ by heterogeneous reactions on the char surface is included.

The model can be run for gas only or coal-gas cofiring. If a coal particle is present, the model assumes hydrodynamic equilibrium between the particle and the gas phase flow. Therefore, the particle follows the flow of the gas. The particle, however, can be at different temperatures than the gas phase; i.e., equilibrium is not reached in a thermodynamic sense. In this instance, a user-prescribed Nusselt number is provided for gas-particle convective heat transfer calculations. The model also uses a simple thin-flame radiative model for the calculation of heat exchange between gas-particle-furnace walls. Radiative species considered are $\mathrm{CO}, \mathrm{CO}_{2}, \mathrm{H}_{2} \mathrm{O}$, and solid particles. In the boiler environment, the thin flame radiation model is considered to be inaccurate, and therefore is not used in this analysis. Instead, the required temperature information for $\mathrm{NO}_{\mathrm{x}}$ modeling is taken from the results of the boiler heat transfer model.

Based on the tools developed, EER has a proven design methodology that permits an optimized reburning system to be designed, and which permits the prediction of site specific impacts of reburning on NOx emissions and boiler performance. 


\subsection{ENGINEERING DESIGN}

\subsection{Gas Reburning System}

\subsubsection{Natural Gas System}

For the two full scale electric utility reburning demonstrations, the reburn fuel used was natural gas. Approximately 15 to 25 percent of the total heat input to the furnace is supplied via natural gas for the reburning process. From this information, one can roughly size the volumetric rate ( $\mathrm{scfm}$ ) requirements for the natural gas to be supplied to the furnace. Standard piping design practices in conjunction with the rate requirements are used to size supply and distribution piping from existing headers within the facility and also, in some applications, pipelines off site.

Line pressures are designed to accommodate volumetric requirements while maintaining reasonable pipe sizes. Normal pressures are $100 \mathrm{psig}$ in headers, $20 \mathrm{psig}$ at the control valve trains, and 1-4 psig at the injection nozzles. On GR installations, with FGR as the inert media for assisting in the penetration and mixing of the natural gas with the furnace gases, the natural gas pressure is supplied to the injection nozzles is slightly above the pressure of the flue gas at the nozzle.

Control of natural gas flow into the furnace is critical not only for optimizing the GR process, but for maintaining boiler firing control and safety. GR itself is a chemical process that is different from combustion, but natural gas flow into the boiler is treated as another fuel input. Specific equipment and design recommendations with regard to gas firing are available in the National Fire Protection Association (NFPA) Standards 85B, "Prevention of Furnace Explosions in Natural Gas-Fired Multiple Burner Boiler-Furnaces", and 85C, "Prevention of Furnace Explosions/Implosions in Multiple Burner Boiler-Furnaces. 


\subsubsection{Flue Gas Recirculation System .}

The mass flow rate of natural gas injected into the reburning zone for the reburning process does not always possess sufficient momentum to penetrate into the furnace flue gases for adequate mixing. As such, an inert gas may be required to be mixed with the smaller amount of natural gas before injection into the furnace via several high velocity jets, the combination of the higher velocity with the higher mass flow providing the necessary momentum for good in-furnace mixing.

The logical source of the inert gas is the combustion flue gas at the boiler exit. At this location in the process, oxygen levels in the flue gas are at their lowest since air heater leakage downstream may significantly increases the oxygen concentration of the flue gas. The temperature of the flue gas extracted at this location eliminates the need for preheating the gas. Note that injection of low temperature gas streams into the furnace may quench the reburning process and contribute to ash and slag formations known as "eyebrows" at the openings.

Selection of the GR nozzle configuration (size, jet velocity, number, and location) is based on furnace gas flow modeling with consideration given to penetration into and mixing with the furnace combustion gases. The velocity head of the flue gas necessary to generate the required nozzle velocity is provided by a FGR fan. Due to the high velocity head requirements with relatively low flow, the FGR fan is a non-standard design having a large rotor diameter (high velocity head) and narrow rotor width (low flow). Although up to eighty percent of abrasive particulate matter is removed upstream of the fan by a multi-cyclone dust collector, the fan should be designed with wear liners to accommodate the fly ash that remains in the gas stream. As with any of the process streams, FGR flow must be metered to control the reburn process. A venturi is the preferred metering device since it can accommodate the ash loading and high temperatures $\left(600^{\circ} \mathrm{F}\right)$. A clean air purge assembly is attached that prevents fly ash obstructions in the pressure sensing lines. 


\subsubsection{Natural Gas Injection}

Natural gas is mixed with high velocity FGR at the injection nozzles. In order to survive the high temperatures of the furnace environment, both water-cooled metal and high temperature ceramic nozzle designs have been used. Nozzle provisions should also be made to resist erosion from fly ash. Cooling fans are required to provide cooling air to the injection nozzles during non-operation of the GR system and to provide seal air on positive pressure units.

\subsection{Sorbent Injection System}

\subsubsection{Sorbent Storage, Feed, Transport, and Distribution}

Sorbent usage rates are calculated from the percentage of sulfur in the coal, the desired reduction in sulfur dioxide, the load (coal flow) anticipated, and the expected utilization of the sorbent (pulverized limestone or hydrated lime). Storage capacity for the sorbent silo is then a function of the desired product inventory, distance of the supplier from the facility, transportation methods and quantities (i.e., truck, rail, barge), and transportation costs.

Storage silo designs are either bolted or welded steel, or combinations of concrete and steel. Bolted steel designs offer the lowest capital cost and ease of construction, but have capacity limitations. The silos must be capable of receiving sorbent via pneumatic unloading equipment without excessive dust emissions. The most common delivery method, over the road bulk trucks, uses positive displacement blowers capable of delivering $600 \mathrm{acfm}$ of air at $15 \mathrm{psig}$ to unload sorbent into the storage silo. The receiving silo must be equipped with a fabric or pleated paper cartridge vent filter to prevent pressurization of the silo while retaining entrained dust. The silos should also be equipped with level detectors to prevent overfilling and combination pressure and vacuum relief valves to protect the silo structure as sorbent is delivered to or fed from the silo. 
Sorbent is discharged from the silo by gravity through a central exit line on the conical bottom of the tank. Bridging and rat-holing at the cone outlet is prevented by fabric air slides using low pressure air to partially fluidize the sorbent and promote flow. Based on experience with limestone and hydrated lime sorbents, silo cone outlets and feed hoppers should have an included angle of approximately sixty degrees.

A wide variety of feed equipment is available to meter the sorbent flow rate from the silo into a pneumatic conveying line. Selection of feed equipment depends on the degree of process control required by the utility. In test or demonstration programs, weigh hoppers fitted with accurate rate-of-weight loss sensors have been used in conjunction with variable speed rotary valves to meter the sorbent flow rate. This configuration allows a feed rate (lbs/hr) display in the main control room. In applications where the utility is only interested in limiting $\mathrm{SO}_{2}$ stack emissions by varying the sorbent flow delivered to the boiler, the weigh hopper and rate of feed indication may not be required. In this case, a variable speed feed device would be used to vary sorbent flow. Sorbent flow rates would then be calculated based on silo inventory.

Feed devices that are commercially available include rotary valves, screw, and belt feeders. Sorbents (especially hydrated lime) will sometimes flow like a liquid through feed devices that do not use positive feed control. Admission of air into the feed system via flow aids (i.e., air slides) may exacerbate this flow problem. Sorbents also have high flowabilty after being pneumatically loaded into the silo. Several hours of settling time may be required after delivery before the sorbent can be fed through the system without handling problems. Despite vendor claims, screw and weigh belt feeders do not offer positive feed control and system upsets are likely if this high flowability condition occurs. Only rotary valves have been successfully used to positively control sorbent feed.

Conveying of the sorbent from the silo feed equipment to the boiler is accomplished via a dilute phase transport system. Dilute phase transport systems operate with a solids 
(sorbent)-to-air ratio of 5 to 1 or less (pound-to-pound basis). Dilute phase transport lends itself well to the distribution of the single sorbent stream into the several streams feeding the injection nozzles since the sorbent is evenly distributed throughout the transport piping. Dense phase or two phase flow systems offer smaller transport piping sizes, but require more complicated flow splitting techniques. Dense phase systems also require higher transport air pressures and therefore more expensive blowers or compressors with higher attendant power consumption.

Dilute phase conveying systems typically operate at pressures of $15 \mathrm{psig}$ or less, allowing the use of positive displacement type (Roots) blowers for the conveying air supply. Line charging equipment is required to inject the sorbent from the feed and metering equipment into the conveying line. This equipment must deliver the sorbent to the conveying line across a pressure differential of up to $15 \mathrm{psig}$, without allowing air leakage back into the feed system which could lead to upsets and increased dust emissions. A solids screw Fuller-Kinyon pump developed and offered by Fuller Company is well suited for this application. The pump uses a screw with progressive flights to compact the sorbent and extrude it though a check valve into the conveying line.

Sorbent is delivered from the silo feed equipment into a single transport line. It is then distributed, or split, equally into several streams to feed the SI nozzles. Several splitter designs have been developed. EER developed its own flow-splitter. The splitter has a conical shape that transforms the cross section flow area at the inlet into an annular, or ring, shaped area at the outlet. The inlet diameter is sized to be identical to the attached sorbent transport hose, and the diameter of the annular outlet is sized just large enough to accommodate the number of outlet pipes required to supply the injectors. The design maintains adequate conveying velocities through the splitter so that saltation of the sorbent does not occur. The splitter relies on a uniform distribution of sorbent in the conveying airstream entering the splitter inlet. In horizontal runs, gravity segregates the sorbent to the bottom of the transport hose, so splitting with this design is done in a vertical 
orientation. A good design rule of thumb is to provide at least twenty diameters of vertical, straight transport hose prior to the splitter inlet.

The sorbent storage silo should be located as close to the furnace as possible to minimize conveying distances. Aside from the rate of sorbent to be conveyed, the distance to be transported strongly determines the conveying air pressure requirements of the system. Conveying systems designed to operate at 12 psig or less can use less expensive positive displacement blower equipment as compared to sliding vane or multistage compressors capable of 15 psig or more.

\subsubsection{Sorbent Injection}

The configuration (number, size, location, and jet velocities) of the SI system is determined during process design. Air supplied by the sorbent conveying process proper is generally not sufficient to provide the required injection nozzle mass flow rates. As such, a booster fan may be required to provide additional air at sufficient velocity head for injection. The booster fan is similar in design to that of the FGR system, having a large diameter to develop the high velocity head, but with minimal width due to the low flow requirements. Since the fan will boost ambient air only, there are no requirements for rotor and housing wear liners.

SI nozzles are typically a coaxial jet design, with the inner pipe used for the sorbent and transport air mixture, and the outer pipe providing the balance of air required for injection, from the separate air booster fan. At the end of the injector nozzle, prior to furnace entry, the sorbent/transport air is mixed with the added injection air, providing the required velocity for sorbent injection into the furnace.

SI nozzles are of typically stainless steel construction to resist corrosion and the high temperature effects of the furnace. With the SI system in operation, the nozzles are cooled 
with the transport and injection air flows. When the SI system is not in service, cooling air flow must be established through the nozzles. Cooling air is supplied by relatively small sized centrifugal fans coupled to the injection air duct work. Since a cooling fan failure could create nozzle slagging of warping problems, redundant fans are normally required.

On positive pressure units, cooling air fans also supply seal air to the SI nozzles to prevent back flow of hot furnace gases into the SI air system. Also on positive fired units, a positive shut-off is provided in the sorbent transport system to prevent back flow of gases into the rubber hose conveying lines and sorbent feed system.

\subsection{Furnace / Boiler}

\subsubsection{Bent Tube Openings}

Depending on results of the process design, application of the GR-SI technology may require as many as thirty tube wall penetrations to be made in the furnace water walls to accommodate the injection nozzles and the furnace gas temperature monitoring equipment. Each water wall opening may require from four to eight bent tubes to be installed, possibly affecting over one hundred of the water wall tube circuits. In considering the application of GR-SI, the impact of the bent tube openings on circulation and steam generation in the lower furnace water walls should be investigated.

\subsubsection{Tube Metals}

SI results in very light colored to white deposits on the tube surfaces of the upper furnace and radiant tube banks of the superheater and reheater. The change in reflectivity of these surfaces can reduce the radiative heat transfer from the furnace gases to the tubes surfaces and shift (increase) the gas temperature profile through the unit. In practice, it has been found that nearly constant sootblowing is required to clean these light deposits 
from the tube surfaces to maintain steam and gas side temperatures. Due to the delayed burn-out associated with the gas reburn process, gas temperatures may also be increased in the same areas. Based on predicted gas temperature increases, the temperature limits of metals used in the existing upper furnace water walls and radiant and convective tube banks should be investigated. If existing metals are shown to be marginal, the utility may opt for monitoring of tube temperatures via pad welded thermocouples during GR-SI operation rather than tube replacement which may not be warranted.

\subsubsection{Air Heater Design}

With the GR-SI operation, the downstream air heater will be affected by increased flue gas temperatures and particulate loading and fouling. Air heater designs on larger utility units may be either of the tubular or regenerative type design. When considering the application of GR-SI a review should be made of the sizing and condition of the existing air heater with the anticipated impacts of increased flue gas temperature and particulate fouling. Tubular air heaters, in poor condition, may require re-tubing to prevent tube failure and limit carryover of the spent sorbent into the combustion air ductwork and control components.

Aging regenerative designs may be temperature limited due to the condition of air heater posts and diaphragms. Regenerative designs may also require replacement or adjustment of radial and circumferential seals to limit carry-over of spent sorbent into the combustion air system. Cleaning of air heater surfaces may be increased from once per shift to nearly continuous with SI. The condition of sootblowing equipment on either design should be evaluated in light of the increased service requirements. Tubular designs may require retrofit of circulating shot cleaning systems to limit fouling to acceptable levels since sootblower effectiveness may be limited on these units. 


\subsubsection{Sootblowing Equipment}

Operation of the GR process results in slight changes to furnace water wall heat flux profiles, but experience has shown no detrimental impact on furnace wall slagging or fouling tendencies. SI however, results in a deposition of a thin and highly reflective (white) deposits on tube surfaces. This deposit layer affects radiation heat transfer in the upper furnace and in the radiant tube banks of the superheater and reheater (if equipped). This deposit layer is dry, not fused to the tube surface, and is easily removed by sootblowing. Experience has shown that nearly continuous operation of long retractable sootblowers is required in the radiant tube bank sections. Since SI takes place in the extreme upper portion of the furnace, the effect on water wall sootblowing requirements is negligible.

Sootblowing equipment should be reviewed with respect to coverage of the radiant sections of the furnace tube banks, age, and capacity of the air or steam supply in light of the expected continual operation. The existing complement of long retractable sootblowers in the radiant tube bank sections should be reviewed in terms of coverage and sootblowing pressure requirements. Additional sootblowers may be required in this area, with the possibility of additional water wall penetrations. Since nearly constant sootblowing is required, poor reliability of the sootblowing equipment may affect unit availability or require $\mathrm{SI}$ to be ceased, resulting in increased $\mathrm{SO}_{2}$ emissions. The reliability assessment should include not only sootblowers but steam and/or air control valves, motor control centers, and system air compressors.

Sootblowing steam or air supply systems may be designed to service more than one unit, and may not have the capacity for normal sootblowing on the non-GR-SI unit(s) when providing the near constant sootblowing demand of the GR-SI equipped unit. Existing systems may also not accommodate air heater sootblowing concurrent with furnace sootblower operation. On air systems, additional sootblowing air compressors may be required. Steam sootblowing systems may be limited by make-up water capabilities or 
feedwater heater capacities. Older units may be operating with sootblowing control equipment that lacks full automation and requires significant boiler operator attention. Consideration should be given to the state-of-the-art sootblowing control equipment with automated programming of a variety of sootblowing sequences, minimizing the operator interface requirements.

\subsubsection{Combustion Air (Overfire Air Source)}

Air required for the OFA system is usually taken from the combustion air system. It has been preheated and may have a sufficient velocity head for injection through the OFA nozzles into the furnace gases. Process design information will provide the necessary OFA flow and velocity head requirements. The existing combustion air supply system is reviewed in terms of fan capacity and available velocity head. Available velocity head can be increased by closing dampers that supply air to the primary combustion zone. However, the capacity of the forced draft fan(s) may be limiting. If capacity is available but the velocity head is not sufficient, a booster fan will be required for the OFA supply.

\subsubsection{FGR Source}

FGR is used as an inert propellant for natural gas in the reburning process. Flue gas is drawn after the last heat transfer tube bank (economizer or boiler bank) as to not affect steam temperatures, and prior to the air heater since leakage there increases the oxygen level of the FGR. The configuration of the duct work leading from the boiler outlet to the air heater inlet should be reviewed with respect to a location for the flue gas tap. The tap should be located such that access to the center of the flue gas duct is possible to minimize tramp air entry. Tramp air (from casing leaks on balance draft units) and seal or cooling air from burners or other furnace water wall penetrations enters the flue gas and follows the furnace and duct walls. The flue gas tap should also be located to allow placement of a multi clone dust collector as close to the gas source as possible. Since the 
gas is cleaned of particulate immediately after being extracted from the boiler exit, problems with ash accumulation and erosion in the FGR duct work are eliminated.

\subsubsection{Equipment Footprint}

Installation of GR-SI systems will require the placement of equipment, duct work and piping in a boiler house that may already be space limited. Following is a list of major GR-SI equipment, duct work and piping for which space requirements should be considered in a GR-SI retrofit:

\section{GR System}

- $\quad$ FGR fan, cooling fans, multi clone ash collector, flow measuring venturi, and interconnecting duct work.

- Natural gas metering, control, and shut-off valve station, and supply, distribution and vent piping.

- OFA duct work and booster fan (if required).

\section{SI System}

- SI air fan, cooling fans, and interconnecting duct work.

- Sorbent transport piping, flow splitter, and distribution hose layout.

\section{Ancillary Equipment}

- New electrical power transformers and motor control centers

- Duct work modifications, air compressors, and water pumps for ESP enhancement humidification systems or chemical flue gas conditioning systems.

- Sootblowing air compressor additions.

- Dry ash handling equipment versus wet sluice systems. 


\subsubsection{Unit Operation}

The location of furnace openings for $\mathrm{SI}$ is highly dependent on the furnace temperature profile which changes significantly with load. Penetrations are therefore located based on the normal load of the unit. The temperature window for optimum sorbent utilization is approximately 2000 to $2250^{\circ} \mathrm{F}$. Operating at higher loads will result in sintering of the surface of the sorbent particle, reducing gas-solid reactions and under-utilizing the sorbent. When operating at lower loads (and temperatures), the gas-solid reactions will continue but at a slower rate, and again, sorbent is under-utilized.

Based on the above, load-following units may not be best suited for upper furnace SI. Units which cycle between full or max load during peak hours, and some reduced or minimum load during off peak, may be fitted with two levels of SI nozzles (upper and lower) to accommodate the two distinct loads and resulting furnace temperature profiles. With any unit that is not base-loaded and to be retrofit with GR-SI technology, turndown capability must also be incorporated into the system design to accommodate the load variations. Turndown capability impacts the equipment and metering of process streams, sorbent flow and transport air requirements, SI air flow, natural gas flow, and FGR flow.

\subsection{Balance of Plant}

\subsubsection{Electrical Power Distribution}

GR-SI process equipment may be supplied power from the plant's auxiliary power system. The existing capacity of the electrical distribution and control system must be reviewed in light of the process needs. The primary electrical power consumers in the GR-SI systems are injection and cooling fan motors, pump and compressor motors, and silo area heat and lighting. Critical equipment such as cooling fans, sootblower controls, boiler controls, and 
turning gear should be supplied from motor control centers having redundant feeds to assure an un-interruptible supply.

\subsubsection{Plant and Instrument Air}

GR-SI system equipment, controls, and instrumentation will require dry instrument quality air for control valve operation, and also seal and cooling air. Plant air will be required for cleaning the baghouses and bin vent filters used on the sorbent unloading and feed equipment. If the furnace is a positive pressure design, plant air will also be required for the aspirated boiler waterwall penetrations.

Existing plant and instrument air systems, including dryers, should be reviewed in terms of capacity and air quality (oil and water content), to determine if the needs of the proposed GR-SI equipment can be met. Air usage by the sorbent silo equipment (baghouses, cleaning, seal, and control air) represents a significant portion of the total GR-SI system air requirements. Because of the remote location of this equipment from the boiler house, consideration should be given to a dedicated compressor and dryer at this location.

\subsubsection{Controls}

Process control equipment and instrumentation installed as part of the GR-SI system will undoubtedly be state-of-the-art digital equipment. A wide variety of boiler control equipment exists in use at utilities representing various generations of pneumatic, analog, and digital control equipment. Equipment installed on any one unit may be a mixture of these technologies, i.e., pneumatic, analog and digital field devices tied to microprocessorbased digital bench board equipment in the control room.

Consideration must be given to the control scheme for the new process equipment, especially in regard to interface capabilities relating to safety interlocks, firing control, and 
safety trips. If the interface capability is present, the utility may opt to add the new process equipment to the existing control equipment provided necessary input/output space is available or can be added, or add additional control equipment for GR-SI operation which interfaces with the existing boiler controls. Particular attention must be paid to proper buffering and isolation of the two controls systems so that the integrity and reliability of the existing boiler control system is maintained, but the transfer of data is also maintained between systems to ensure proper control strategy. Lacking the proper interface capability, an upgrade of the entire control room equipment may be warranted.

Since the GR process relies on setting precise stoichiometric ratios in the main burner, reburn, and burnout zones, above average combustion air control methods are required. Control systems that operate from an air-to-coal curve (lbs. of air per lb. of coal) do not lend themselves well to retrofit of the GR technology. This control method does not make adjustments for changes in coal heating value, moisture content, and air density, and actual stoichiometric ratios may differ from those desired. Since with GR, natural gas replaces a portion of the coal input to the unit, complicated control schemes are required on units operating under an air-to-fuel curve. The addition of boiler $\mathrm{O}_{2}$ trim into the air control scheme can overcome these awkward limitations and optimize the GR process. $\mathrm{O}_{2}$ trim is provided by in-situ flue gas oxygen analyzers located at the boiler outlet. State of the art control systems allows $\mathrm{O}_{2}$ trim to be biased for the oxygen not participating in the combustion and burn-out processes which enters the flue gas via SI air flow or other tramp air sources (wall box seal air or casing leakage).

\subsubsection{Silo Footprint}

A sorbent storage silo with capacity for several days of operation cannot be erected within a typical boiler house, and is therefore located at ground level at the nearest available site. SI transport systems use dilute phase conveying to simplify distribution of the sorbent to the several injection nozzles. Aside from the sorbent flow rate, the length of the conveying 
hose from the silo to the boiler-contributes to the conveying system pressure drop and dictates the size (horsepower) of the conveying blower or compressor.

Silo product load, as well as wind load and seismic design requirements, dictate a heavy silo foundation, usually supported by structural steel or pressure grouted pilings. Site selection must consider constraints on placement of the foundation, including possible relocation of underground facilities.

\subsubsection{Particulate Control}

Control of particulate emissions from utility boilers is accomplished by baghouses and electrostatic precipitators (ESPs), the latter being the most used on larger units. With regard to baghouses, the sole consideration is the increase in particulate mass to be collected (up to forty percent). If not already equipped, a multi-cyclone collector (multi clone) may be added upstream of the bag house to collect the larger particle size constituents of the ash, reducing the loading on bag house. Based on the sizing and design of the existing bag house, it may be necessary to modify the bag house by adding additional compartments.

Operation of an existing ESP will be significantly impacted by the SI process. Impacts include increased particulate loading by a factor of two, a dust resistivity increase of a factor of one hundred due to decreased sulfur trioxide concentrations in the flue gas, and further increases in resistivity with increases in flue gas temperature as the boiler and air heater become fouled with sorbent. Unless the existing ESP is generously sized, some type of precipitator enhancement or expansion will be required. Precipitator enhancement technologies include chemical addition to the flue gas such as sulfur trioxide or ammonia gas, or cooling of the flue gas via duct humidification for reduction of ash resistivity. EER selected humidification over chemical treatment for enhancement of marginally-sized ESPs, since it was speculated that only humidification could maintain baseline emissions 
and had a higher probability of success. The capital and operating costs for addition of electrical fields to a precipitator must be compared to the alternative of chemical treatment or humidification. It must be noted that humidification requires at least two seconds of residence time in a straight run of duct to ensure complete evaporation of the introduced water spray. Duct work modifications, as well as possible relocation of draft fans, must be considered with the cost of humidification equipment as compared to chemical treatment or precipitator modifications.

\subsubsection{Ash Handling}

Depending on the boiler design (tangential, wall, or cyclone fired), SI can potentially increase the particulate loading to the ash handling equipment by as much as forty percent. It should be noted that since the SI process takes place in the upper furnace, it does not significantly impact bottom ash handling requirements. Due to the increased flue gas particulate mass to be handled, the utility considering SI should review the capacity of its existing economizer, air heater, and precipitator hoppers. Special consideration should be given to hoppers which experience flow problems, possibly being modified in design with steeper slopes, flow liners, or flow aids such as air cannons or vibrators.

Ash handling systems should be reviewed in terms of capacity (especially when servicing several units), general reliability, and required operator attention. Consideration should be given to automated ash handling control retrofits in lieu of additional operating labor requirements.

Handling systems which use a sluice water eductor (hydroveyor) have experienced problems with cementitious deposits in the throat of the eductor. Here, dust passing through the collection device mixes with water to form a cement and accumulates to the point that the necessary vacuum to operate the system becomes no longer possible. Ash handling system vendors have encountered this problem with the high calcium ashes of 
Western lignites, and have designed rams or scrapers to manually clean these systems without disassembly.

\subsubsection{Ash Disposal}

The GR process has no detrimental effect on the quality of the fly ash (carbon-in-ash) with respect to the ability to sell the ash, nor does it affect the chemical composition. SI however, adds a significant portion of partially sulfated sorbent to the total make-up of the ash product. With regard to wet (sluice) disposal practices, the $\mathrm{pH}$ of the sluice water is increased dramatically (10 to 13) with the addition of the partially used sorbent. Most state and federal environmental regulatory agencies limit the $\mathrm{pH}$ of discharge from ponds or settling basins to a range of $\mathrm{pH} 6$ to $\mathrm{pH} 9$. Carbon dioxide injection systems have been successfully used to neutralize sluice water in the conveying piping. Further treatment may be necessary at the pond out-fall due to continued chemical reactions taking place in the settling pond(s).

Design of ash retention ponds must be reviewed with respect to the increased particulate mass to be accommodated as well as changes in the chemical properties in the ash. Such a review should include pond sizing, settling time requirements, liners, leachate collection, and monitoring wells.

Facilities that have existing dry ash handling equipment, or are considering retrofit in light of the ash changes and disposal requirements, may consider sales of the high-calcium fly ash to cement companies that have used the ash as an admixture for cement and concrete. Design and permitting of existing dry ash disposal landfills may also prohibit disposal of the fly ash produced with $\mathrm{SI}$, and disposal alternatives may be required. 


\subsection{SYSTEM OPERATION --}

\subsection{Control System}

Control and monitoring of the GR-SI system is not complicated and may be accomplished with any modern control system that can be integrated into an existing boiler control system. The design of the GR-SI control system is based on the following criteria:

- All normal operations that are required to start, stop, or modulate the various pieces of equipment shall be performed in the control room.

- Sufficient information shall be displayed in the control room to enable the operator to determine the status of all equipment. The operator interface shall be designed so that the above information is displayed in a manner to enable rapid understanding of system status.

- Certain operations shall be interlocked to prevent inadvertent operation of equipment when such operation may present an operating hazard or other undesirable condition.

- $\quad$ Certain shut-down procedures shall be initiated automatically by the control system when such operations are deemed necessary for safety or good operating practice.

- Microprocessor based technology shall be used for the controls and interlocks.

- Operator interface shall be of the Keyboard-CRT type with custom graphics.

- The system will readily interface with existing plant instrumentation and be of a design that will enable operator familiarity and understanding with a minimum of training.

Interlocks are included which are designed to start the equipment in an orderly fashion and prevent the operator from allowing the unit's safety to become compromised either through erroneous operation or due to equipment failure. All major commands issued by the 
control system are verified by a feedback signal. Trip signals are continuously monitored and will prevent startup or shutdown of equipment already in operation.

\subsection{Operation}

\subsubsection{Gas Reburning System}

The GR system is composed of three integrated systems: (1) natural gas injection, (2) FGR, and (3) OFA injection. The natural gas flow rate is controlled to the desired value for optimum $\mathrm{NO}_{\mathrm{x}}$ destruction. The $\mathrm{FGR}$ flow is controlled at a rate that provides adequate natural gas momentum for optimum mixing in the furnace. The OFA is controlled to a rate to complete combustion of all unburned fuel leaving the reburning zone. The three integrated systems are interlocked, operated and monitored by the control system.

The control logic for natural gas injection consists of a flow controller which receives a calculated set point from the boiler master and the natural gas flow transmitter. A comparison is made in the fuel controller between the set point and feedback signals and the controller output modulates the natural gas control valve to reduce any error to zero. The boiler master controls gas flow with coal flow to obtain the Btu input needed over the load range. A percentage of the boiler master signal is calculated and becomes the set point for the desired natural gas flow.

The desired FGR flow control set point is a calculated value determined from the boiler master signal. This set point signal is compared with the actual value of FGR flow rate in a PID controller which acts on any detected error signal. The control system will automatically adjust the FGR fan to reduce the error to zero.

Control of the OFA system consists of sending a set point signal calculated from the boiler master signal to a controller where it is compared with the total of the OFA air flows. The 
OFA nozzles are modulated to-reduce any detected difference in the set point and total OFA flow to zero. The control system compares the signals from the OFA flow transmitters to balance the flow of air.

Another control feature of the GR system is the cross limit between the OFA flow and natural gas flow. The set point for natural gas is compared with the OFA flow. If the natural gas flow set point is greater than the amount of OFA flow required for complete combustion of natural gas, the control system will decrease the natural gas set point to a value that permits complete combustion of the natural gas by the OFA. If the natural gas flow is greater than the OFA flow, the set point signal for OFA is increased to a value that will permit complete combustion of the natural gas. The above sequence is called cross limiting between the fuel (natural gas) and OFA and is very similar to the cross limiting features in the main combustion control between the coal feed and secondary air flow.

There is another cross limit between the FGR flow and the natural gas flow. If the FGR flow falls below a value that insures optimum penetration of the natural gas into the boiler (i.e., good mixing with the products of the coal combustion process), the set point for natural gas flow will be reduced to a safe value.

\subsubsection{Sorbent Injection System}

The SI system has three (3) variables that are modulated by the control system to obtain a targeted sulfur emissions reduction while maintaining maximum sorbent utilization. These include a rotary feeder to control sorbent feed rate, a control valve to control sorbent transport air flow, and a control damper to control injection air flow. The operator set point for $\mathrm{SO}_{2}$ is the value that is compared with the input from the flue gas $\mathrm{SO}_{2}$ analyzer in a PID controller. The output of the PID controller is used as a multiplier for the "total" coal flow rate to give a sorbent flow demand rate. This calculated value for sorbent flow demand rate becomes a set point value for two control loops. The first control loop, sorbent flow 
demand rate,-sets the initial value-for sorbent feed rate controlled by the rotary feeder. In this loop a set point is compared with the actual measured value of sorbent feed in a PID controller. The output of the PID controller modulates the speed of the rotary feeder.

As demand for sorbent increases or decreases depending on sorbent flow demand, there is a also a requirement to increase or decrease the sorbent transport air flow. Therefore, in the second control loop the calculated sorbent flow demand rate set point is compared with the sorbent transport air flow in a PID controller which modulates the air flow control valve to increase or decrease the amount of air flow as required.

The last control loop regulates the amount of injection air flow required to inject the sorbent into the boiler. Any error between the set point and actual flow rate is acted on by the PID controller whose output is summed with the initial value of the control signal to the injection flow control damper, thereby reducing any error to zero.

\subsection{Optimization}

\subsubsection{Gas Reburning System}

Optimization of the GR system is performed using a series of parametric tests to characterize the independent reburning variables and associated responses of the system at various boiler loads. By using this data, the appropriate set points can be established for a range of $\mathrm{NO}_{\mathrm{x}}$ emissions reductions. Prior to optimization, baseline tests are performed in order to establish both the pre- and post-installation boiler conditions without GR in operation. Five independent variables are involved in the parametric tests including:

- $\quad$ Boiler load -- A sufficient number of load conditions must be tested to develop the curve generators for the control system that enable automatic load-following. 
- $\quad$ Percentage of total heat input proportioned to natural gas The coal flow is reduced in direct proportion to the natural gas injected into the reburning zone.

- $\quad$ Percentage of total flue gas used in FGR The FGR system is used to provide momentum to the injected natural gas for optimum mixing with the boiler flue gas. The level of FGR directly impacts the $\mathrm{NO}_{x}$ conversion capabilities of the system.

- $\quad$ Percentage of total combustion air used at OFA OFA impacts the ability to burnout the remaining combustibles in the flue gas.

- $\quad$ Primary zone stoichiometric ratio $\left(\mathrm{SR}_{1}\right)$ Low $\mathrm{SR}_{1}$ 's are optimal for $\mathrm{NO}_{\mathrm{x}}$ reduction. However, the utility must establish the lower limit of $\mathrm{SR}_{1}$ that minimizes the potential for corrosion in the bottom of the boiler. Flame appearance must also be acceptable. For cyclone boilers, there will be little change in $\mathrm{SR}_{1}$ due to the operational fuel-to-air ratio constraints characteristic of cyclones. The optimum $\mathrm{SR}_{1}$ will be in the range of 1.05 to 1.15 , depending on boiler type.

Dependent variables include:

- $\quad$ Reburning zone stoichiometric ratio $\left(\mathrm{SR}_{2}\right) \mathrm{SR}_{2}$ is directly proportional to the natural gas heat input for an established $S_{2}$ condition. At a zero gas condition, $\mathrm{SR}_{2}$ is equal to $\mathrm{SR}_{1}$. As gas is introduced, $\mathrm{SR}_{2}$ decreases. The optimum level of $\mathrm{SR}_{2}$ is around 0.90 .

- Burnout zone stoichiometric ratio $\left(\mathrm{SR}_{3}\right)$ All combustion air not used in the primary zone becomes OFA. Depending on the excess air level selected by the utility, $\mathrm{SR}_{3}$ will be approximately 1.15 .

Stoichiometric ratios are calculated using boiler data collected during the tests. Additional test data are used to measure boiler emissions and assess operating characteristics. The following measurements are used:

- $\quad$ Stack emissions These include $\mathrm{NO}_{\mathrm{x}}, \mathrm{O}_{2}, \mathrm{CO}$, and $\mathrm{CO}_{2}$.

- Control room data Data are used to calculate the stoichiometric ratios, thermal efficiency and heat absorption. 
- Coal samples Samples are evaluated to determine coal fineness, composition and volatility.

- $\quad$ Ash samples Samples are evaluated to determine carbon-in-ash and loss of ignition.

- In-furnace measurement HVT tests are used to characterize the temperature and flow stratifications in the boiler for comparison with process design models. The HVT is also used to assess CO distribution.

- Visual observation The potential for slagging and fouling of boiler tubes and other areas of the boiler are assessed.

Parametric testing is performed using a pre-planned test matrix. The matrix involves various combinations of the five dependent variables listed above to determine the effects on $\mathrm{NO}_{\mathrm{x}}$ emissions and other boiler responses. Evaluation of these results plus consideration of any unique boiler operating constraints are required to approximate the optimal set points for reburning operation. Additional tests are performed using minor adjustments to the dependent variables to fine tune the system. Once the set points are established for various load conditions, the data are entered into the control system providing for an automatic load following capability.

\subsubsection{Sorbent Injection System}

Optimization of the SI system is performed with a series of parametric tests in order to characterize the independent variables and associated responses of the system at different boiler loads. By using this data and performing additional optimization tests, the appropriate set points can be established for a range of $\mathrm{SO}_{2}$ emissions reductions. Prior to optimization, baseline tests are performed to establish both the pre- and post-installation boiler conditions without SI in operation. Five independent variables are involved in the parametric tests including: 
- $\quad$ Boiler load A-sufficient number load conditions must be tested in order to develop the curve generators for the control system that enables automatic load-following operation.

- $\quad$ Calcium-to-sulfur ratio This ratio is proportional to the reduction in $\mathrm{SO}_{2}$ emissions.

- $\quad$ Percentage of total combustion air used as injection air Injection air provides momentum to the sorbent when injecting it into the furnace to enhance mixing.

- Sorbent type Significant characteristics include the method of preparation, surface area, particle size, and density. These factors can have an impact on the reduction in $\mathrm{SO}_{2}$ emissions. Each sorbent has unique handling characteristics, some of which may not be suitable for specific transport equipment.

- $\quad$ Sootblowing cycle The degree of sootblowing carried out impacts the boiler steam temperature and efficiency.

The following measurements are used to perform an SI evaluation:

- $\quad$ Stack emissions These include $\mathrm{SO}_{2}, \mathrm{O}_{2}$, and opacity.

- Control room data Data are used to calculate the thermal efficiency and heat absorption.

- Electrostatic precipitator performance The removal efficiency of the ESP is evaluated to determine if the equipment has a sufficient number of fields to remove the additional particulate resulting from SI.

- Visual observation The potential for slagging and fouling of boiler tubes, air heater and other areas of the boiler are assessed.

Parametric testing is performed using a pre-planned test matrix. The matrix involves various combinations of the five dependent variables listed above to determine the effects on $\mathrm{SO}_{2}$ emissions and other boiler responses. Evaluation of these results plus consideration of any unique boiler operating constraints are required to approximate the optimum set points for $\mathrm{SI}$ operation. Additional tests are performed using minor adjustments to the dependent variables to fine tune the system. Once the set points are 
established for various load conditions, the data are entered into the control system permitting automatic load following capabilities.

\subsubsection{Gas Reburning-Sorbent Injection System}

The optimum conditions for GR with SI may be different from those without SI. Therefore, another of series of tests are required to simultaneously optimize the combined GR-SI system. Cross-over effects of GR and SI include the following:

- $\quad \mathrm{GR}$ results in a measured reduction in $\mathrm{SO}_{2}$ through the replacement of $\mathrm{SO}_{2}-$ laden coal with natural gas. The benefit is directly proportional to the gas rate used.

- $\quad$ GR results in a measured reduction in particulate, proportional to the amount of natural gas used. This results in an increased margin for particulate control with the ESP.

- Natural gas in the GR process adds moisture to the flue gas, that decreases the resistivity of the particulate. Offsetting this may be the reduction in sulfur trioxide formation due to less coal sulfur entering the furnace. Lower resistivities, within a range, are beneficial for the removal of spent sorbent in the ESP. 


\subsection{TECHNOLOGY PERFORMANCE}

This section presents the results of field GR-SI parametric testing conducted at Illinois Power Company's Hennepin Unit \#1, located in Hennepin Illinois, and City Water Light and Power's Lakeside Unit \#7, located in Springfield, Illinois. The GR-SI process involves the injection of reburning fuel (in this case natural gas) into the furnace above the coal burners for reduction of nitrogen oxides $\left(\mathrm{NO}_{x}\right)$ and injection of dry sorbent into the upper furnace for capture of sulfur dioxide $\left(\mathrm{SO}_{2}\right)$. The parametric test results were selected for presentation here to show the effect of various process parameters on GR-SI performance.

During field evaluations, a wide range of boiler operating conditions and GR-SI parameters were tested to determine the optimum conditions for $\mathrm{NO}_{x}$ and $\mathrm{SO}_{2}$ emission reductions. The project goals of 60 and $50 \%$ reductions in $\mathrm{NO}_{x}$ and $\mathrm{SO}_{2}$, respectively, were achieved for both demonstrations. The two GR-SI demonstrations are discussed sequentially and for discussion purposes the GR and SI system process performances are presented separately followed by brief comments and data on the integrated GR-SI systems.

\subsection{Hennepin Unit \#1 GR-SI Demonstration}

A GR-SI demonstration was completed on Illinois Power Company's Hennepin Unit \#1. It is a $71 \mathrm{MW}_{\mathrm{e}}$ (net) tangentially fired utility boiler and the primary fuel is an Illinois Bituminous coal containing approximately $3 \mathrm{wt} \%$ sulfur. The goals of the project were to reduce emissions of $\mathrm{NO}_{x}$ and $\mathrm{SO}_{2}$ by 60 and $50 \%$, respectively.

\subsubsection{GR Results}

To fully evaluate the impact of GR on boiler emissions, Unit \#1 baseline $\mathrm{NO}_{x}$ and $\mathrm{CO}$ emissions were measured and compared with average GR results, see Figure 5-1. During baseline tests, $\mathrm{NO}_{\mathrm{x}}$ emissions of up to $0.77 \mathrm{lb} / 10^{6} \mathrm{Btu}(331 \mathrm{mg} / \mathrm{MJ})$, were measured at full 


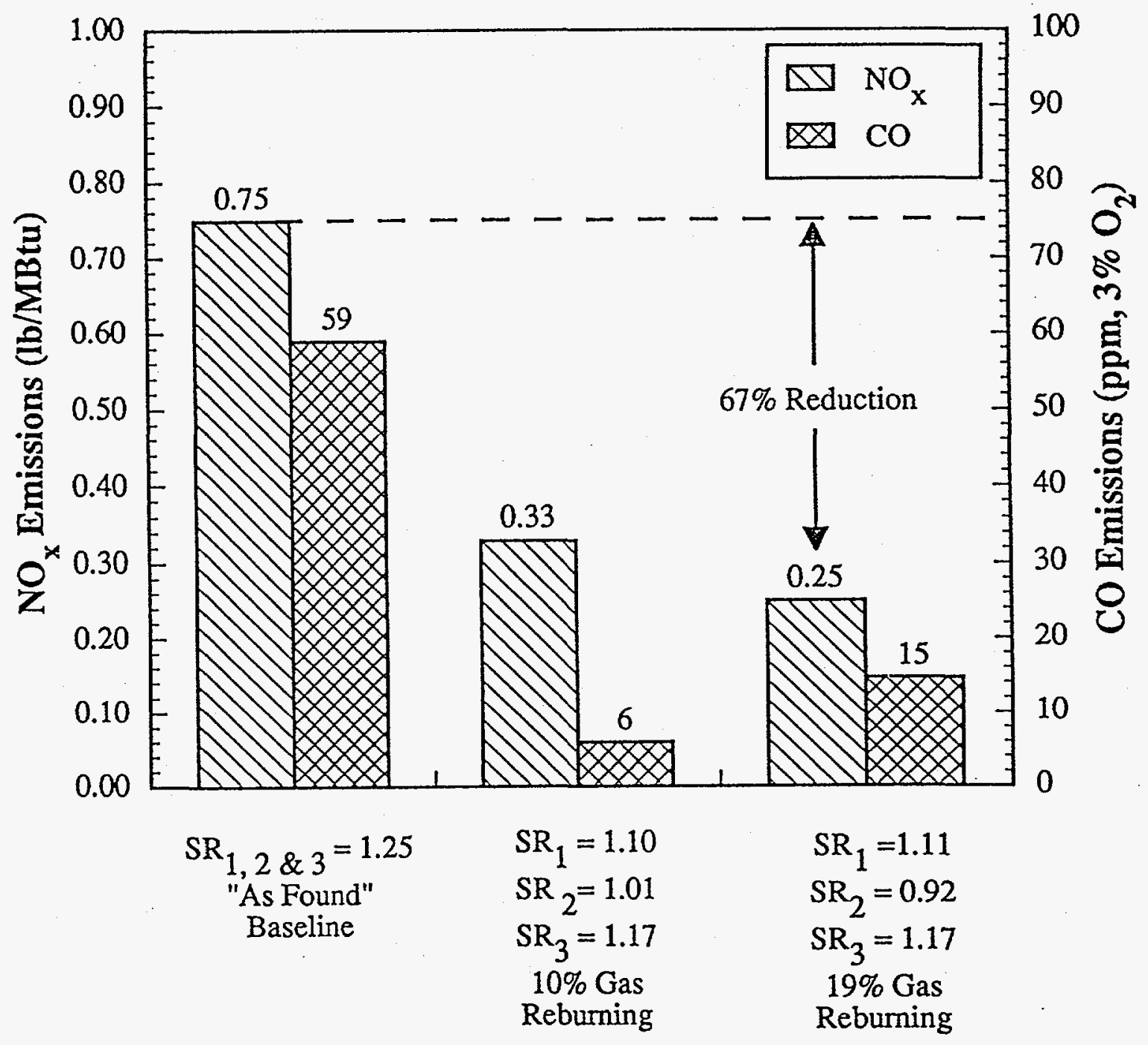

Figure 5-1. Baseline and Gas Reburning NOx and CO emissions. 
load with excess air levels of-up to $25 \%$. Lower $\mathrm{NO}_{\mathrm{x}}$ emissions were observed at decreased boiler loads. At $60 \mathrm{MW}_{\mathrm{e}}, \mathrm{NO}_{\mathrm{x}}$ emissions averaged approximately $0.48 \mathrm{lb} / 10^{6} \mathrm{Btu}$ (206 mg/MJ). For comparison purposes, $0.75 \mathrm{lb} \mathrm{NO}_{x} / 10^{6} \mathrm{Btu}(323 \mathrm{mg} / \mathrm{MJ})$ was used as the baseline for all full load tests. The GR optimization tests showed $\mathrm{NO}_{\mathrm{x}}$ emission averages that ranged from a low of $0.19 \mathrm{lb} / 10^{6} \mathrm{Btu}(81 \mathrm{mg} / \mathrm{MJ})$ to a high of $0.36 \mathrm{lb} / 10^{6} \mathrm{Btu}$ (157 mg/MJ), operating with gas heat inputs ranging from 10 to $22 \%$, primary zone stoichiometric ratios ranging from 1.06 to 1.15 , and reburn zone stoichiometric ratios ranging from 0.88 to 1.01 .

GR was operated with a furnace exit excess air level of $15-18 \%$ compared to the baseline level of 20 to $25 \%$. At Hennepin, the GR system was designed to maximize $\mathrm{NO}_{x}$ emission reductions for an $18-20 \%$ reburn gas heat input. The goal was to achieve a minimum of $60 \% \mathrm{NO}_{x}$ reduction. Figure $5-1$ shows that the $\mathrm{NO}_{x}$ reduction goal was achieved.

The GR system was optimized by varying the key process parameters that affect $\mathrm{NO}_{\mathrm{x}}$ emissions. One of those parameters is the primary zone air/fuel stoichiometric ratio (SR). The primary zone SR established for the Hennepin Unit was in the range of 1.08 to 1.10 . Further testing established optimum conditions for FGR, burner tilt, and reburning zone SR to reduce $\mathrm{NO}_{x}$ emissions to $0.25 \mathrm{lb} / 10^{6} \mathrm{Btu}(108 \mathrm{mg} / \mathrm{MJ})$ or less. Following is an analysis of the major parameters that were varied to optimize the $\mathrm{GR} \mathrm{NO}$ reduction performance:

- Zone stoichiometric ratios

- $\quad$ Percentage of FGR

- Boiler operational parameters

\subsubsection{Zone Stoichiometric Ratios}

The three combustion zones of the reburning process (primary, reburn, and burnout) were analyzed. The effect of primary zone $\mathrm{SR}$ on $\mathrm{NO}_{x}$ emissions under full load GR operation 
with $18 \%$ gas heat input, is illustrated in Figure 5-2. During testing of this variable, the primary zone SR was operated over the range of 1.07 to 1.11. $\mathrm{NO}_{\mathrm{x}}$ emissions increased from an average of $0.21 \mathrm{lb} / 10^{6} \mathrm{Btu}(90 \mathrm{mg} / \mathrm{MJ})$ at an SR of 1.07 to $0.26 \mathrm{lb} / 10^{6} \mathrm{Btu}(112$ $\mathrm{mg} / \mathrm{MJ}$ ) at an SR of 1.11. The increase in $\mathrm{NO}_{\mathrm{x}}$ emissions was due to two factors: higher $\mathrm{NO}_{x}$ formation in the combustion zone and a slight increase in the reburning zone SR which reduced the $\mathrm{NO}_{x}$ control level. During this test, $\mathrm{CO}$ emissions were maintained at a maximum of $3 \mathrm{ppm}$, indicating complete fuel burnout was achieved.

Fly ash samples were collected from various full load tests to determine if low operating primary zone stoichiometric ratios would increase carbon loss. At a primary zone SR above 1.06 , carbon in fly ash varied from 2.2 to $5.2 \%$ as compared to the baseline value of $2.6 \%$. Operating the primary combustion zone at an SR of 1.07 provided sufficient combustion air to provide for good carbon burnout.

The reburning zone $\mathrm{SR}$ is the most important parameter regarding $\mathrm{NO}_{x}$ reduction. The primary zone SR sets how much reburning fuel is needed to reduce the reburn zone to its optimum SR of 0.90 . In most cases, reburning fuel accounted for 18 to $20 \%$ of the total heat input into the furnace. Figure 5-3 shows the impact of reburning zone SR on $\mathrm{NO}_{x}$ emissions. For operation with a primary zone SR between 1.07 and 1.13, $\mathrm{NO}_{x}$ emissions were $0.22 \mathrm{lb} / 10^{6} \mathrm{Btu}(95 \mathrm{mg} / \mathrm{MJ})$ at a reburning zone SR of 0.90 . In addition, CO emissions were less than $25 \mathrm{ppm}$.

The burnout air (OFA) completes the combustion process and brings the combustion system to its normal operating exit flue gas condition SR. In practice, GR allowed the system to operate at lower overall excess air levels. Figure $5-4$ shows the $\mathrm{NO}_{x}$ emissions levels achievable under baseline operation, staged combustion only without $G R$, and $G R$ operation. Baseline tests with overall excess air levels ranging between 13 and $21 \%$ resulted in $\mathrm{NO}_{x}$ emissions ranging from $0.52 \mathrm{lb} / 10^{6} \mathrm{Btu}(224 \mathrm{mg} / \mathrm{MJ})$ to $0.77 \mathrm{lb} / 10^{6} \mathrm{Btu}(331$ 


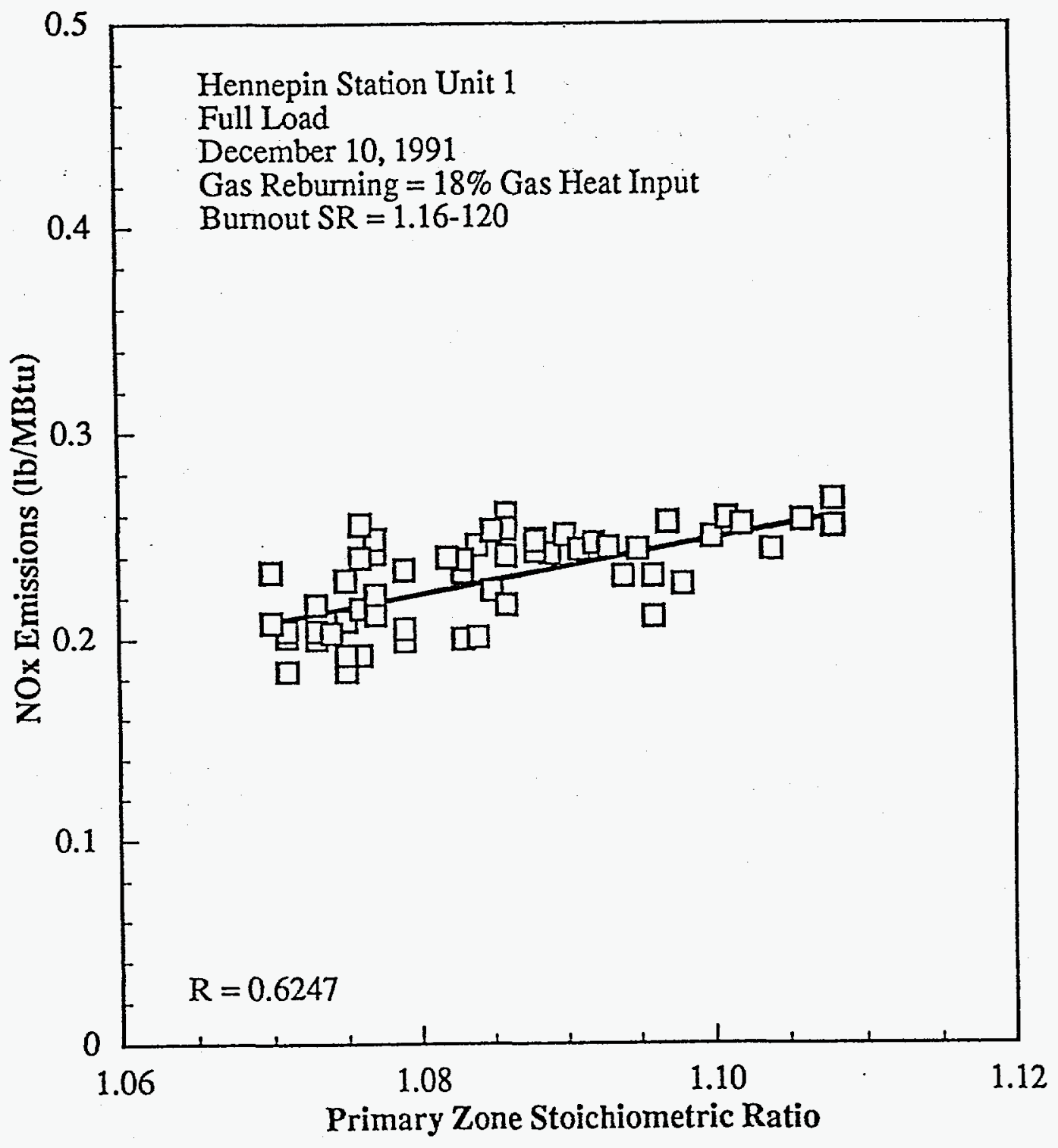

Figure 5-2. Effect of primary air on $\mathrm{NO}_{x}$ emissions 


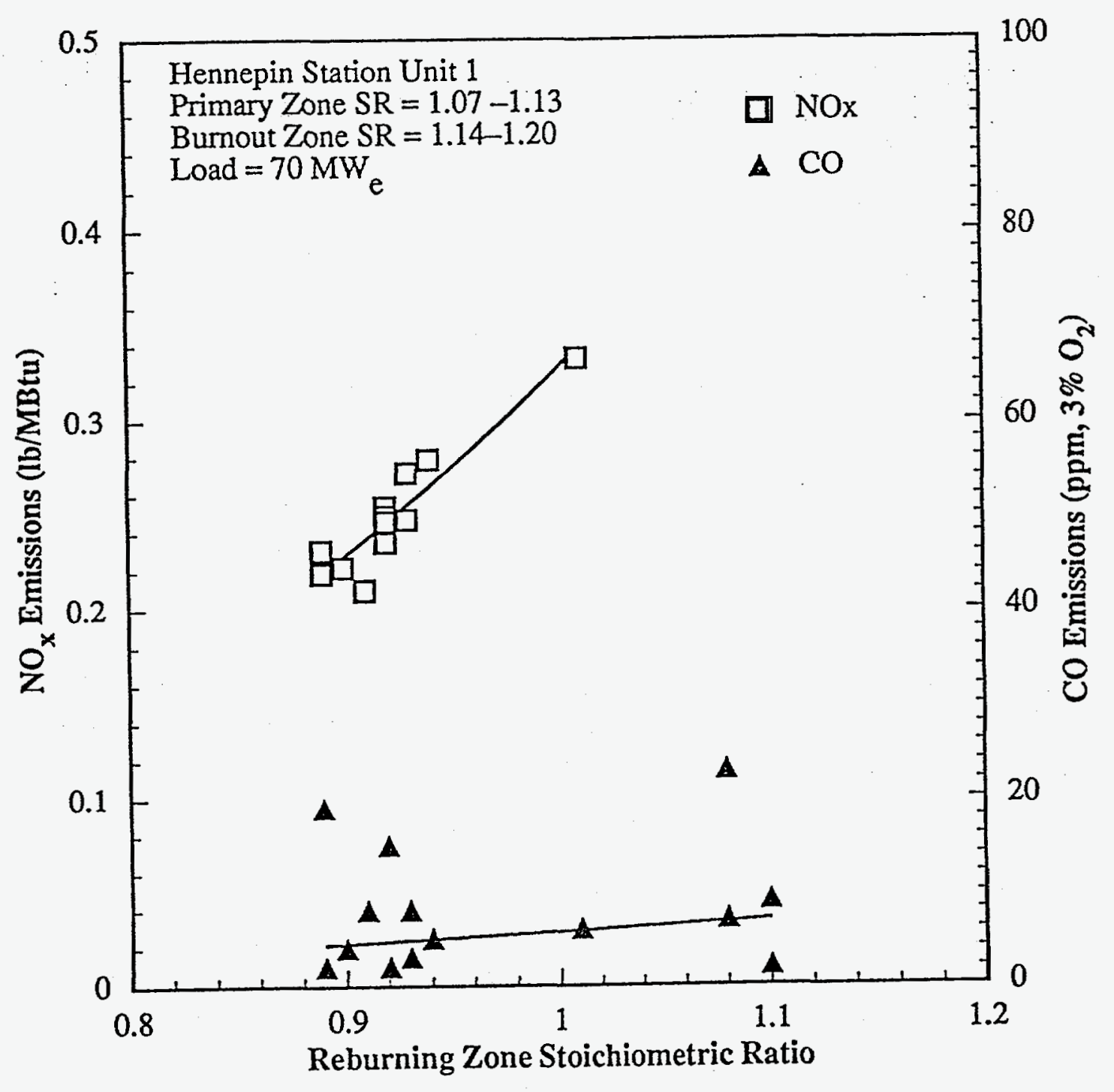

Figure 5-3. Effect of reburning zone stoichiometry on NOx emissions 

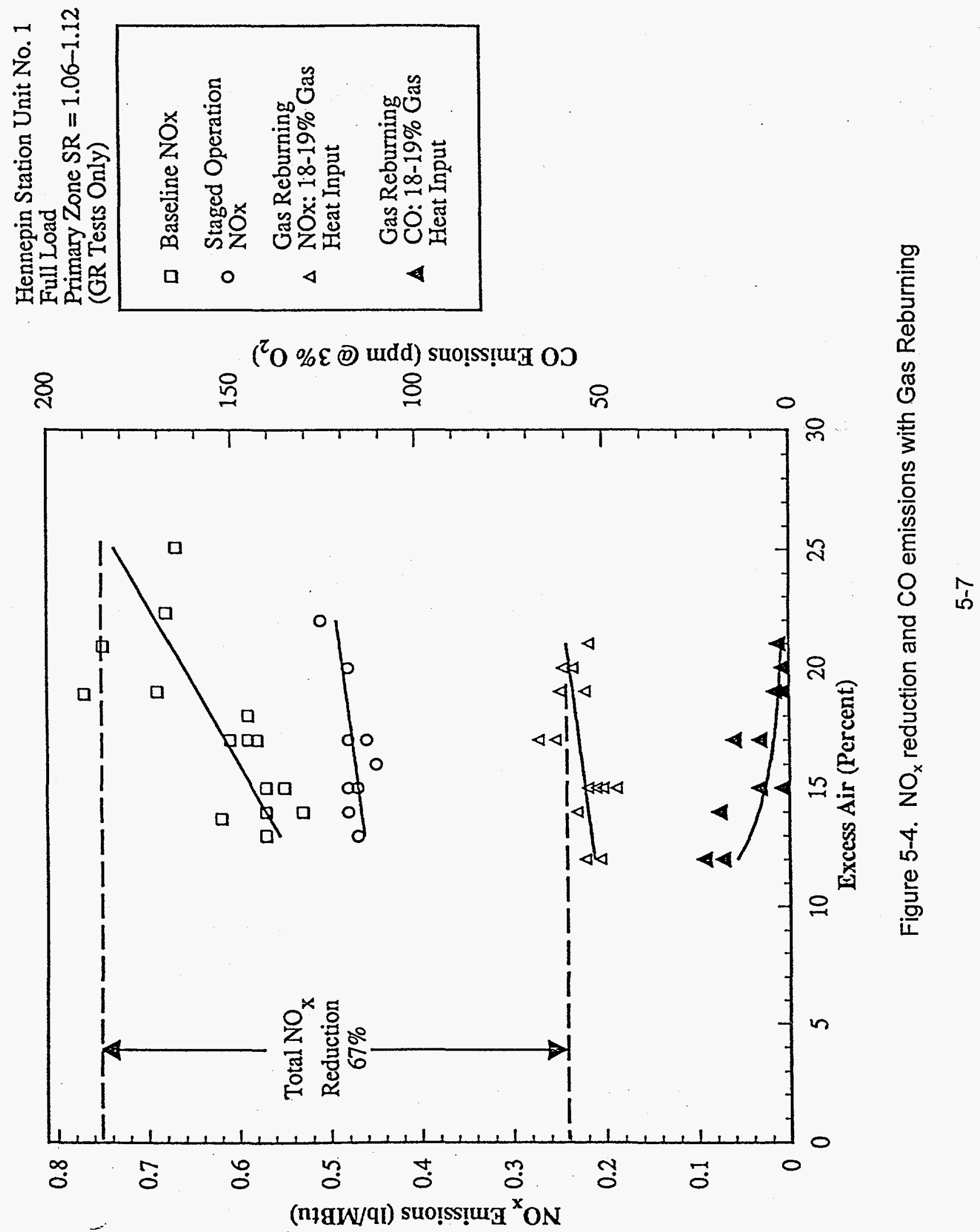
$\mathrm{mg} / \mathrm{MJ}$ ). Staged combustion without $\mathrm{GR}$ showed $\mathrm{NO}_{\mathrm{x}}$ emissions ranging from 0.46 $\mathrm{lb} / 10^{6} \mathrm{Btu}(198 \mathrm{mg} / \mathrm{MJ})$ to $0.51 \mathrm{lb} / 10^{6} \mathrm{Btu}(219 \mathrm{mg} / \mathrm{MJ})$ or $\mathrm{NO}_{\mathrm{x}}$ reductions ranging from 32 to $38 \%$ less than the baseline value at normal excess air conditions. GR was run with overall excess air levels ranging from 12 to $21 \%$. The total $\mathrm{NO}_{x}$ reduction from the uncontrolled level, when utilizing $18 \%$ excess air at the burnout zone, was $0.25 \mathrm{lb} / 10^{6} \mathrm{Btu}$ (108 mg/MJ) or approximately a $67 \%$ reduction in $\mathrm{NO}_{\mathrm{x}}$.

\subsubsection{Flue Gas Recirculation}

In the GR optimization test series, the focus was to optimize mixing by varying the FGR flow rate. In this report, FGR flow rates are expressed as a percentage of the total flue gas flow exiting the furnace.

To determine the effect of mixing on $\mathrm{NO}_{x}$ emissions, tests were run with three levels of FGR at full load and with primary SR values ranging from 1.08 and 1.12 . Figure 5-5 illustrates the effect of $\mathrm{FGR}$ on $\mathrm{NO}_{x}$ emissions performance as a function of the reburn zone stoichiometric ratio. Satisfactory mixing performance was evident for FGR levels between 2.6 and $3.6 \%$. As the reburn fuel rate was increased, the difference in NOx reductions achieved for 2.6 and $3.6 \%$ FGR flow was insignificant. However, lower FGR flows had a slightly negative impact on $\mathrm{NO}_{x}$ emissions performance. Hennepin Unit \#1 had a good reburn zone residence time $(0.55 \mathrm{sec})$ and this minimized the need for FGR. For units with 0.50 second and greater, enough residence time occurs so that the reburn $\mathrm{NO}_{\mathrm{x}}$ reducing reactions can occur. With lower reburn zone residence times, FGR helps establish the reburn zone more quickly and thus a greater $\mathrm{NO}_{x}$ reduction is seen.

\subsubsection{Boiler Operational Parameters}

One of the main objectives of the project was to design a process that would be effective throughout the entire operating range of the unit for the purpose of load following on 


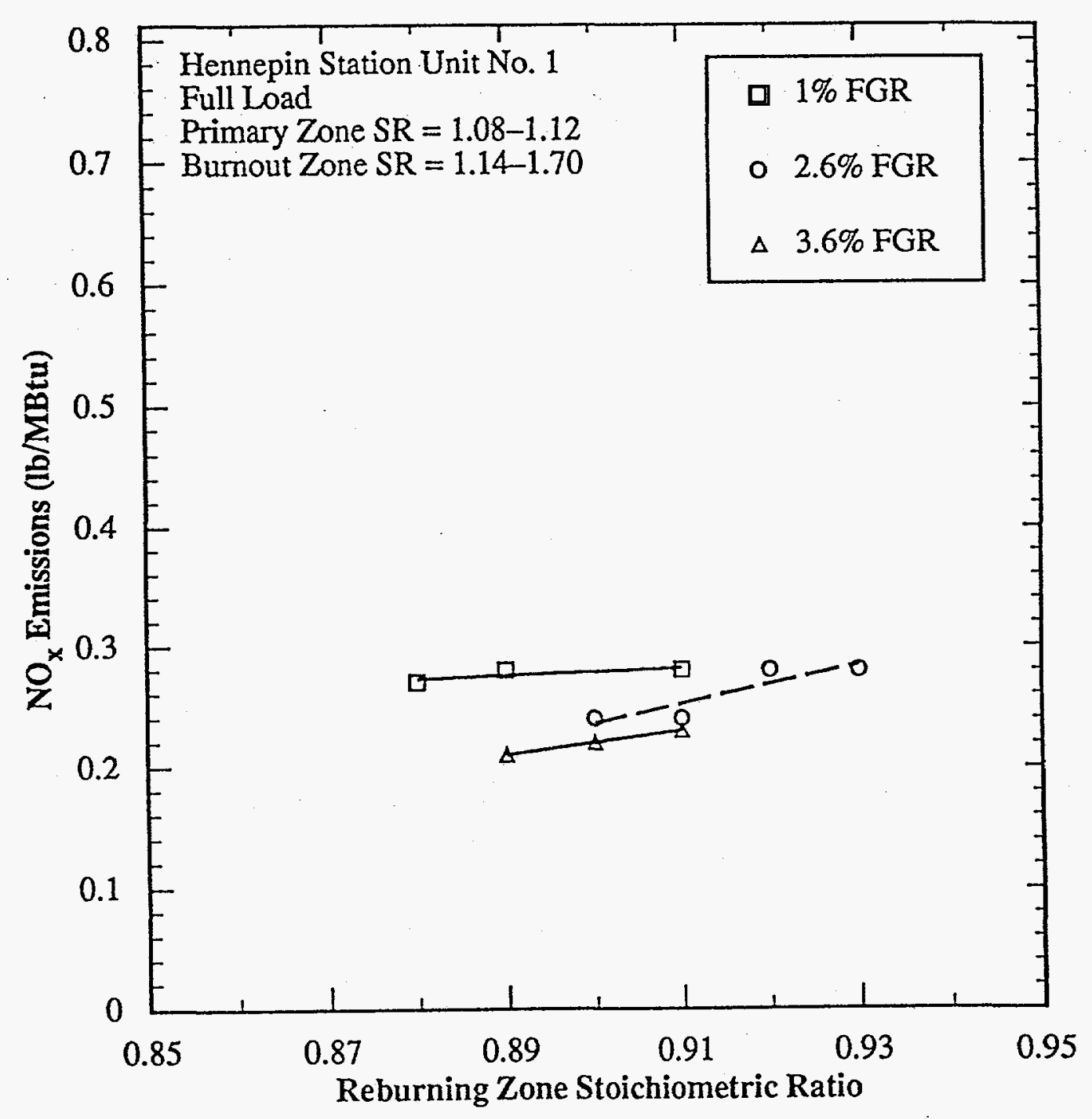

Figure 5-5. Effect of FGR on $\mathrm{NO}_{x}$ emissions 
dispatch control. Optimization tests were conducted at loads from 40 to $75 \mathrm{MW}_{\mathrm{e}}$. The boiler operational parameters that were evaluated included:

- Reburning Fuel Injector/Coal Burner Tilt Angle

- Boiler load

- Coal mills in service

- $\quad$ Furnace temperature profile

Reburning Fuel Injector/Coal Burner Tilt Angle The reburning fuel injectors were equipped with tilting mechanisms that allowed them to inject reburning fuel at the same angle as the coal burners. During the optimization test series, the reburning fuel injector tilts were tested through their full angle of rotation with no appreciable change in reduction of $\mathrm{NO}_{x}$ emissions. The purpose of tilting reburning fuel injectors was to follow the primary burner tilts and thus the fire ball. Conceptually, this would allow a consistent separation between the two zones to allow combustion of the primary fuel to proceed nearly to completion, and provide the necessary reburn zone residence time. Figure 5-6 illustrates that reburning injector/coal burner tilting resulted in a negligible change in $\mathrm{NO}_{x}$ emissions as the injector tilt angle varied from horizontal to -27 degrees at full load. The injector tilting capability was eliminated after optimization testing.

Boiler Load The impact of boiler load on GR performance is due to the primary $\mathrm{NO}_{\mathrm{x}}$ emissions level and gas temperature profile. As was observed in the baseline tests, baseline $\mathrm{NO}_{x}$ levels varied from $0.75 \mathrm{lb} / 10^{6} \mathrm{Btu}(323 \mathrm{mg} / \mathrm{MJ})$ at $75 \mathrm{MW}_{\mathrm{e}}$, to $0.48 \mathrm{lb} / 10^{6} \mathrm{Btu}$ $(206 \mathrm{mg} / \mathrm{MJ})$ at $60 \mathrm{MW}_{\mathrm{e}}$, to $0.50 \mathrm{lb} / 10^{6} \mathrm{Btu}(215 \mathrm{mg} / \mathrm{MJ})$ at $45 \mathrm{MW}_{\mathrm{e}}$. Figure 5-7 illustrates the effect of load on $\mathrm{NO}_{x}$ emissions. The baseline $\mathrm{NO}_{\mathrm{x}}$ emissions were not measured at constant excess $\mathrm{O}_{2}$; therefore some variations must be attributed to varying excess air levels. Data at $70 \mathrm{MW}_{e}$ have already been thoroughly discussed. At $60 \mathrm{MW}_{\mathrm{e}}, \mathrm{GR}$ performance is affected by lower primary $\mathrm{NO}_{x}$ levels entering the reburning zone and lower 


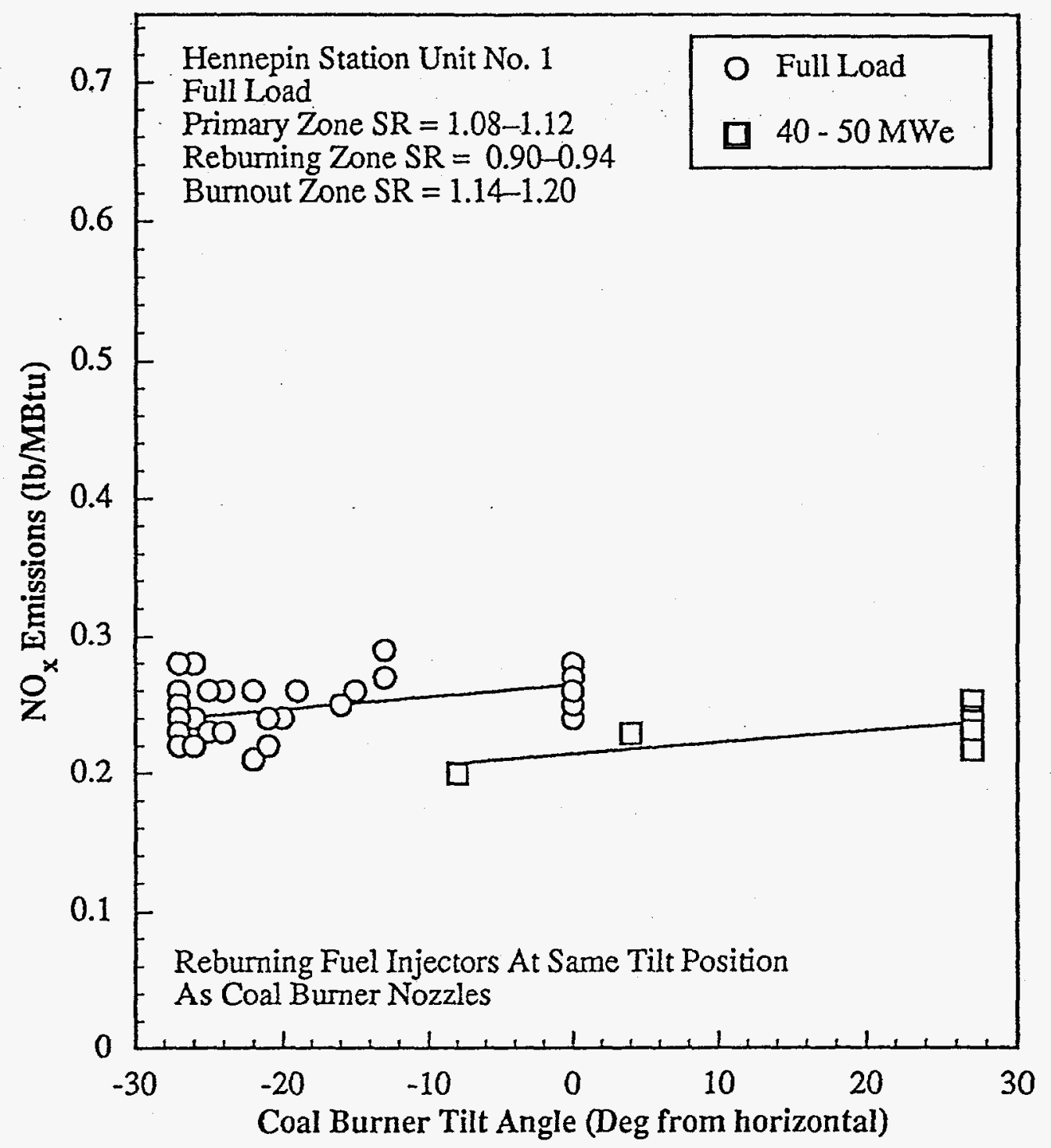

Figure 5-6. Effect of burner tilt on $\mathrm{NO}_{\mathrm{x}}$ emissions 


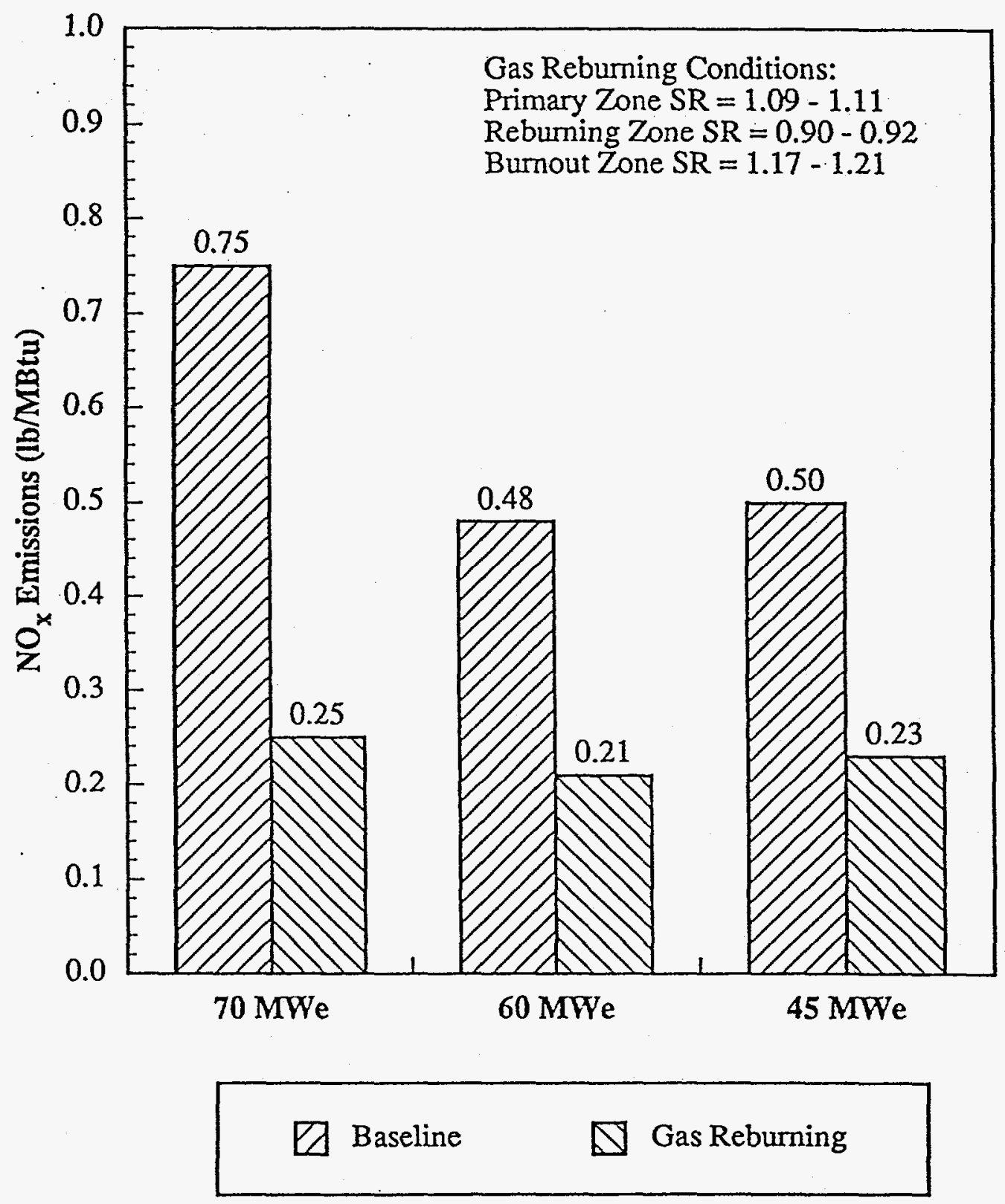

Figure 5-7. Effect of boiler load on $\mathrm{NO}_{x}$ emissions 
furnace temperature. At low toad, $45 \mathrm{MW}_{\mathrm{e}}$, the boiler was operated with 2 mills in operation and with the burner tilts raised to $+27^{\circ}$ to maintain reheat steam temperature, similar to operation at $60 \mathrm{MW}_{\mathrm{e}}$. GR NOx reduction at $45 \mathrm{MW}_{\mathrm{e}}$ was also lower due to a decreased reburning zone gas temperature and lower initial $\mathrm{NO}_{\mathrm{x}}$.

Mills in Service At Hennepin, the normal mode of operation at loads below $55 \mathrm{MW}_{\mathrm{e}}$ with $\mathrm{GR}$ is with two mills in service. The top row of burners is fed by Mill $C$, the middle row of burners is fed by Mill B, and the bottom row of burners is fed by Mill A. The effects of mills out of service at low load was evaluated without GR. Taking Mill $C$ out of service, with no $\mathrm{GR}$, resulted in a reduction in $\mathrm{NO}_{\mathrm{x}}$ emissions due to combustion staging, see Figure 5-8.

Reburn Zone Gas Temperature Gas temperature measurements were taken to evaluate the impact of gas temperature on GR NOx reduction. GR is more effective at higher reburning zone temperatures due to increased kinetics and more rapid formation of hydrocarbon fragments and free radicals. The reburning zone temperatures may reflect the primary zone temperature in indicating the completeness of primary zone coal combustion. Figure 5-9 shows $\mathrm{NO}_{x}$ emissions as a function of reburning zone $\mathrm{SR}$, at two reburn gas temperatures. As expected, the $\mathrm{NO}_{x}$ emissions were slightly lower for the higher temperature case for SRs less than one (reducing conditions). The reverse is true for SRs greater than one (oxidizing condition).

\subsubsection{SI Results}

Baseline $\mathrm{SO}_{2}$ emissions averaged $5.24 \mathrm{lb} / 10^{6} \mathrm{Btu}(2,250 \mathrm{mg} / \mathrm{MJ})$ over the test period and sorbent $\mathrm{SO}_{2}$ capture ranged from a low of $25.3 \%$ to a high of $60.6 \%$. Figure $5-10$ illustrates typical $\mathrm{SO}_{2}$ emissions trends during $\mathrm{GR}$ and GR-SI operation. Initial baseline $\mathrm{SO}_{2}$ emissions were taken prior to commencing GR for a period of 15 to 30 minutes. When reburning fuel was injected into the furnace, a second baseline level was established, prior to commencing SI. Once $\mathrm{SI}$ was initiated, $\mathrm{SO}_{2}$ emissions began to decrease but did 


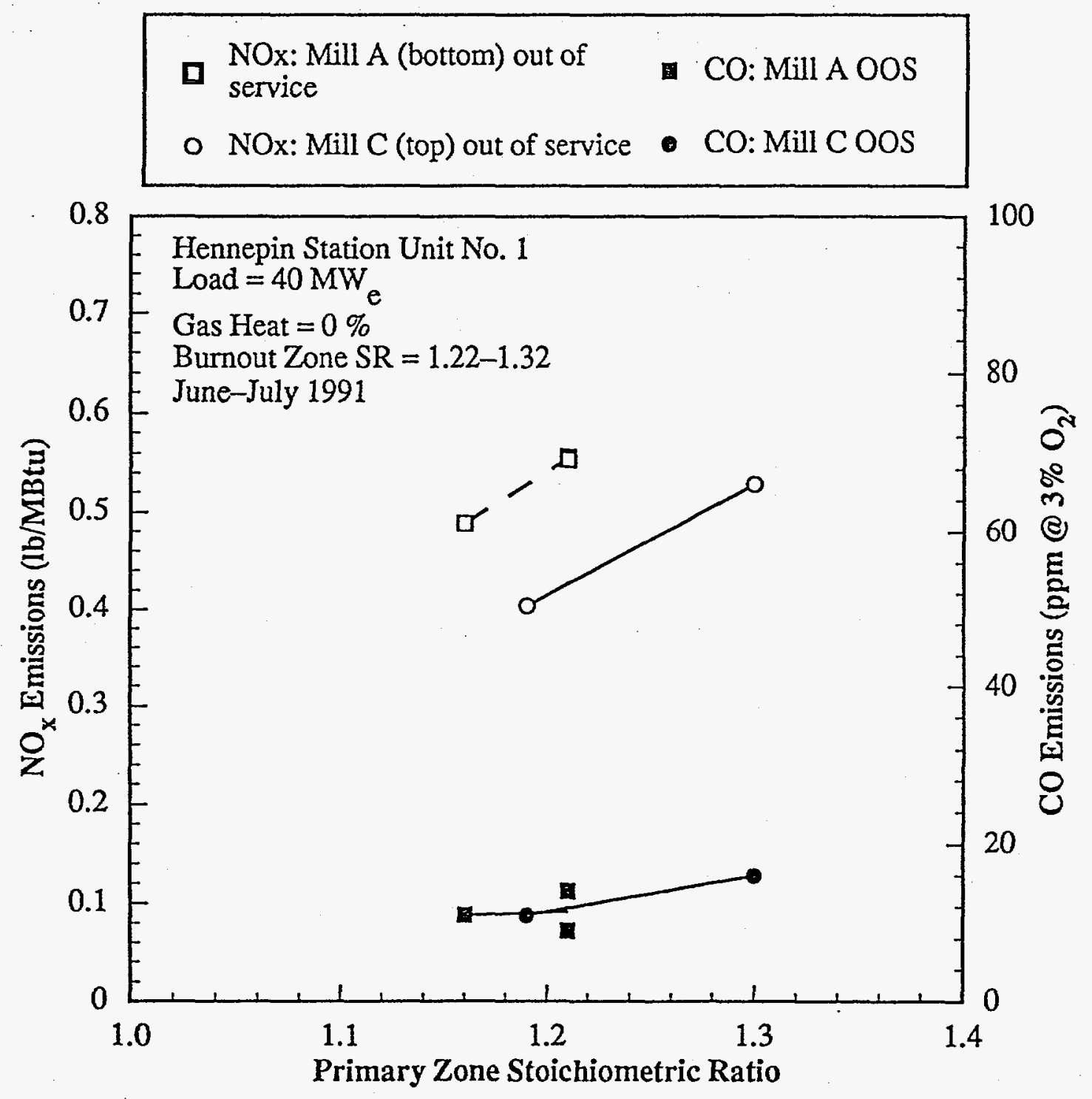

Figure 5-8. Effect of mills out of service at low loads 


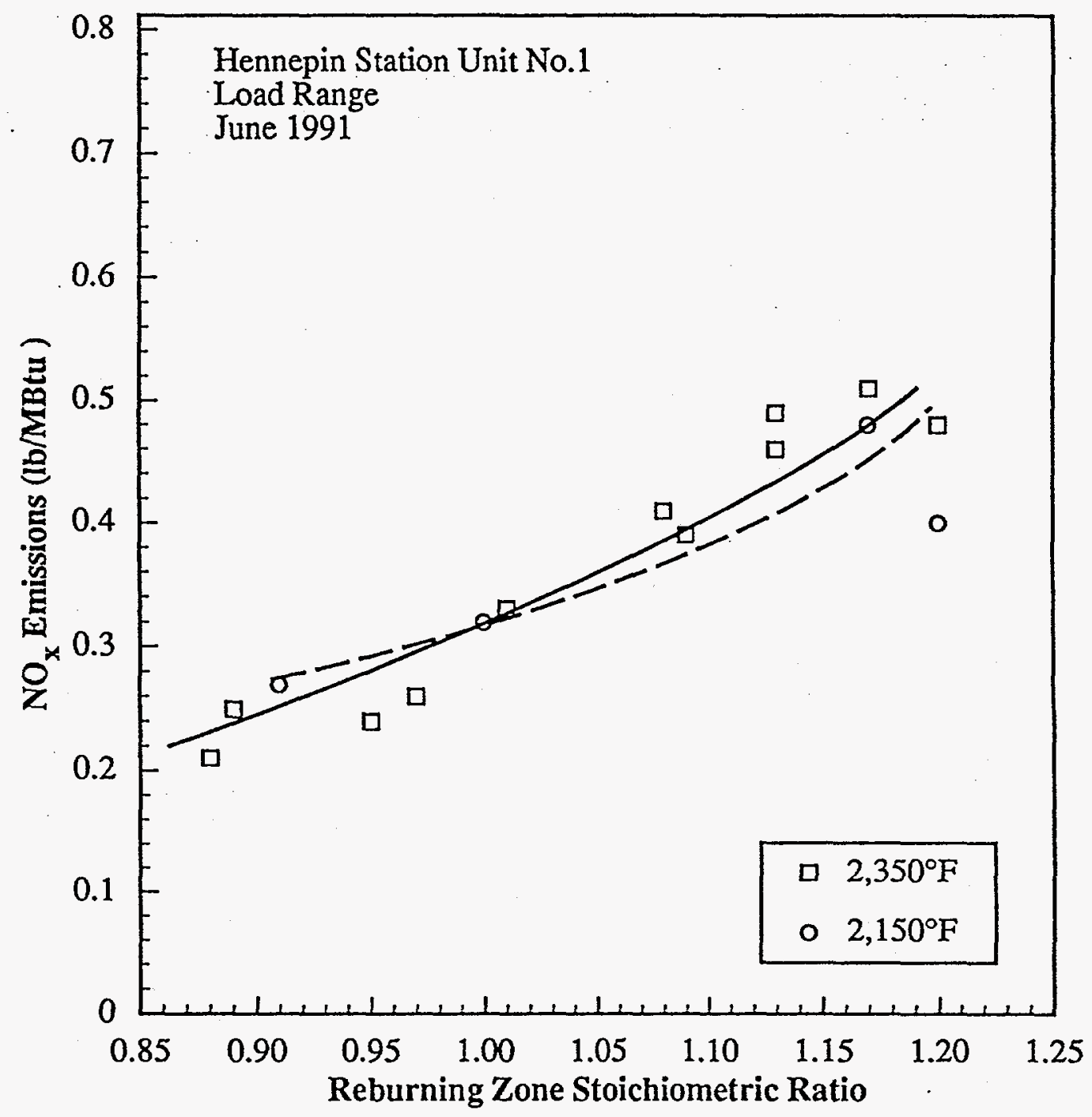

Figure 5-9. Effect of reburn zone $\mathrm{SR}$ and temperature on $\mathrm{NO}_{x}$ emissions 


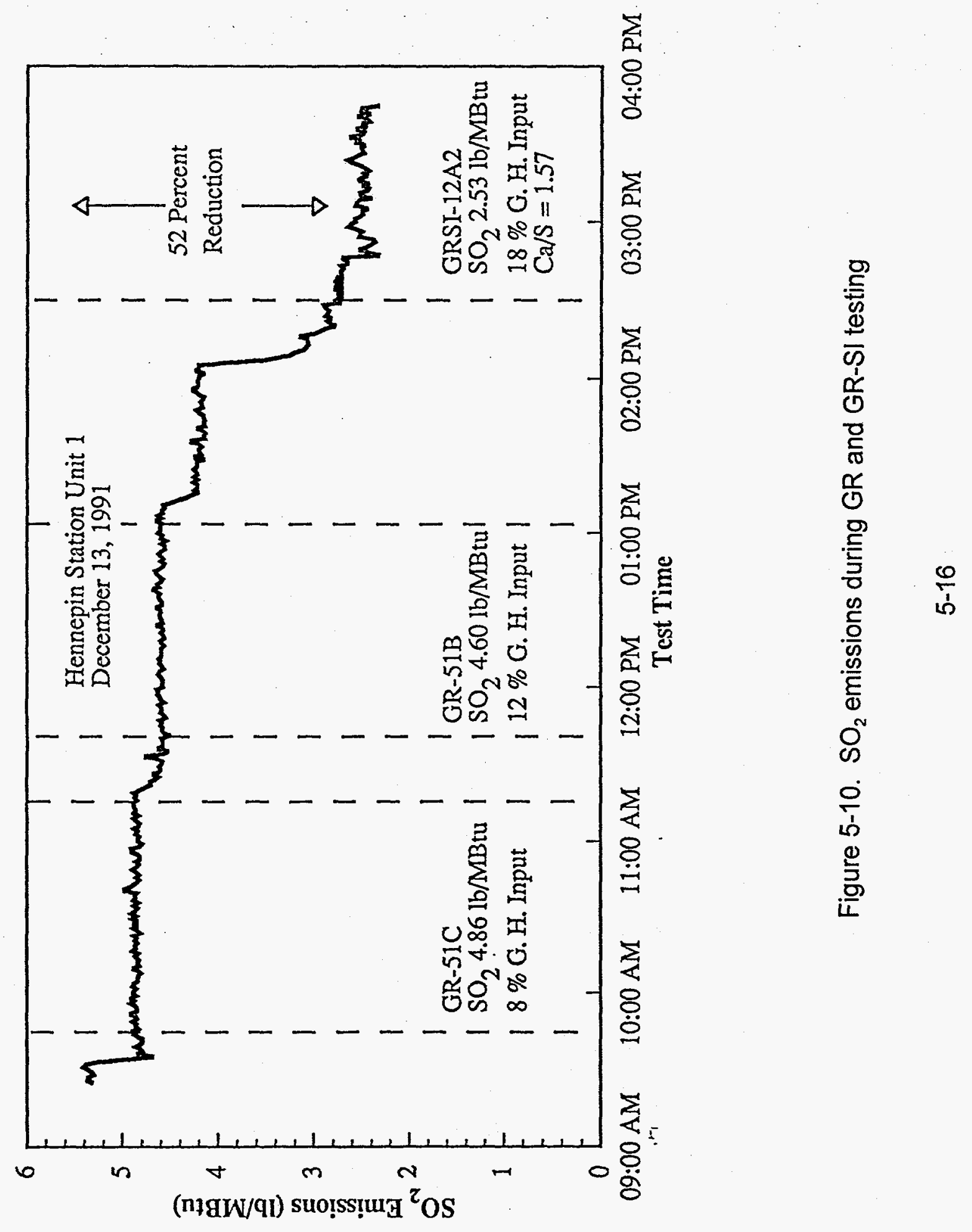


not reach steady state for about 30 minutes. Collection of test data did not begin until the steady state condition existed. GR tests showed the expected $\mathrm{SO}_{2}$ reductions, at 8 and $12 \%$ reburn gas heat input compared to baseline, 8 to $13 \% \mathrm{SO}_{2}$ reductions occurred. The GR-SI test, showed an $\mathrm{SO}_{2}$ reduction of $52.6 \%$, when operating with $18 \%$ reburn gas heat input and a $\mathrm{Ca} / \mathrm{S}$ of 1.57 .

Studies of the SI process showed that six major parameters control the utilization of sorbent, and hence the cost effectiveness of the SI process. The parameters are:

- Sorbent reactivity

- Temperature

- Sorbent dispersion

- Ca/S molar ratio

- Injection configuration

- Boiler operational impacts

\subsubsection{Sorbent Reactivity}

Reactivity refers to a sorbent's ability to react with $\mathrm{SO}_{2}$. The sorbents tested at Hennepin were all calcium hydroxide $\left[\mathrm{Ca}(\mathrm{OH})_{2}\right]$ based. Upon introduction into the furnace, the sorbent undergoes calcination to produce $\mathrm{CaO}\left[\mathrm{Ca}(\mathrm{OH})_{2}+\right.$ heat $\left.\rightarrow \mathrm{CaO}+\mathrm{H}_{2} \mathrm{O}\right]$. The $\mathrm{CaO}$ reacts with $\mathrm{SO}_{2}$ to form calcium sulfite $\left[\mathrm{CaO}+\mathrm{SO}_{2} \rightarrow \mathrm{CaSO}_{3}\right]$ and calcium sulfate $[\mathrm{CaO}+$ $\left.\mathrm{SO}_{2}+1 / 2 \mathrm{O}_{2} \rightarrow \mathrm{CaSO}_{4}\right]$

The reactivity of the $\mathrm{CaO}$ can be enhanced by altering the hydrating process used to form the calcium hydroxide. Also, the smaller the particle size, the greater the surface area and the better the reactivity. The three advanced sorbents tested in this project, were produced with promoting agents to increase the $\mathrm{CaO}$ reactivity. 


\subsubsection{2 - Temperature}

The furnace temperature at the point of sorbent introduction has a pronounced impact on $\mathrm{CaO}$ reactivity. Injection at high temperatures tends to sinter the surface of the $\mathrm{CaO}$ producing a low reactivity "dead burned" material. The optimum injection temperature for most sorbents is around $2,200^{\circ} \mathrm{F}\left(1,204^{\circ} \mathrm{C}\right)$. The temperature history of the sorbent following injection also affects its ability to capture $\mathrm{SO}_{2}$. The $\mathrm{CaO}$ reacts readily with $\mathrm{SO}_{2}$ when injected; however, the reaction rate degrades as the temperature drops and is negligible at about $1,600^{\circ} \mathrm{F}\left(871^{\circ} \mathrm{C}\right) . \mathrm{SO}_{2}$ control with $\mathrm{SI}$ is enhanced by long residence time in the $1,600^{\circ} \mathrm{F}$ to $2,200^{\circ} \mathrm{F}$ temperature window.

\subsubsection{Sorbent Dispersion}

Dispersion of sorbent throughout the complete flue gas stream is also important to ensure that the $\mathrm{SO}_{2}$ has an opportunity to contact the sorbent particles for the longest possible time within the temperature window. EER's SI design methodology evaluated all of these factors. A combination of field measurements, heat transfer modeling and isothermal physical flow modeling was used to establish the furnace gas temperature and flow patterns. Optimum injection temperatures (and hence locations) were selected based on the sorbent characteristics measured in bench scale reactivity tests. Alternate arrangements of the sorbent injectors were evaluated. Physical flow modeling was used to finalize the SI design.

\subsubsection{Ca/S Molar Ratio}

Extensive bench scale testing and computational modeling has shown that sorbent $\mathrm{SO}_{2}$ capture efficiency is related to the $\mathrm{SO}_{2}$ concentration in the flue gas and the $\mathrm{Ca} / \mathrm{S}$ molar ratio. The effect of $\mathrm{Ca} / \mathrm{S}$ on $\mathrm{SO}_{2}$ control is shown in Figure 5-11 for three loads. Full load predictions are also shown for comparison and are in good agreement with the data. Since 


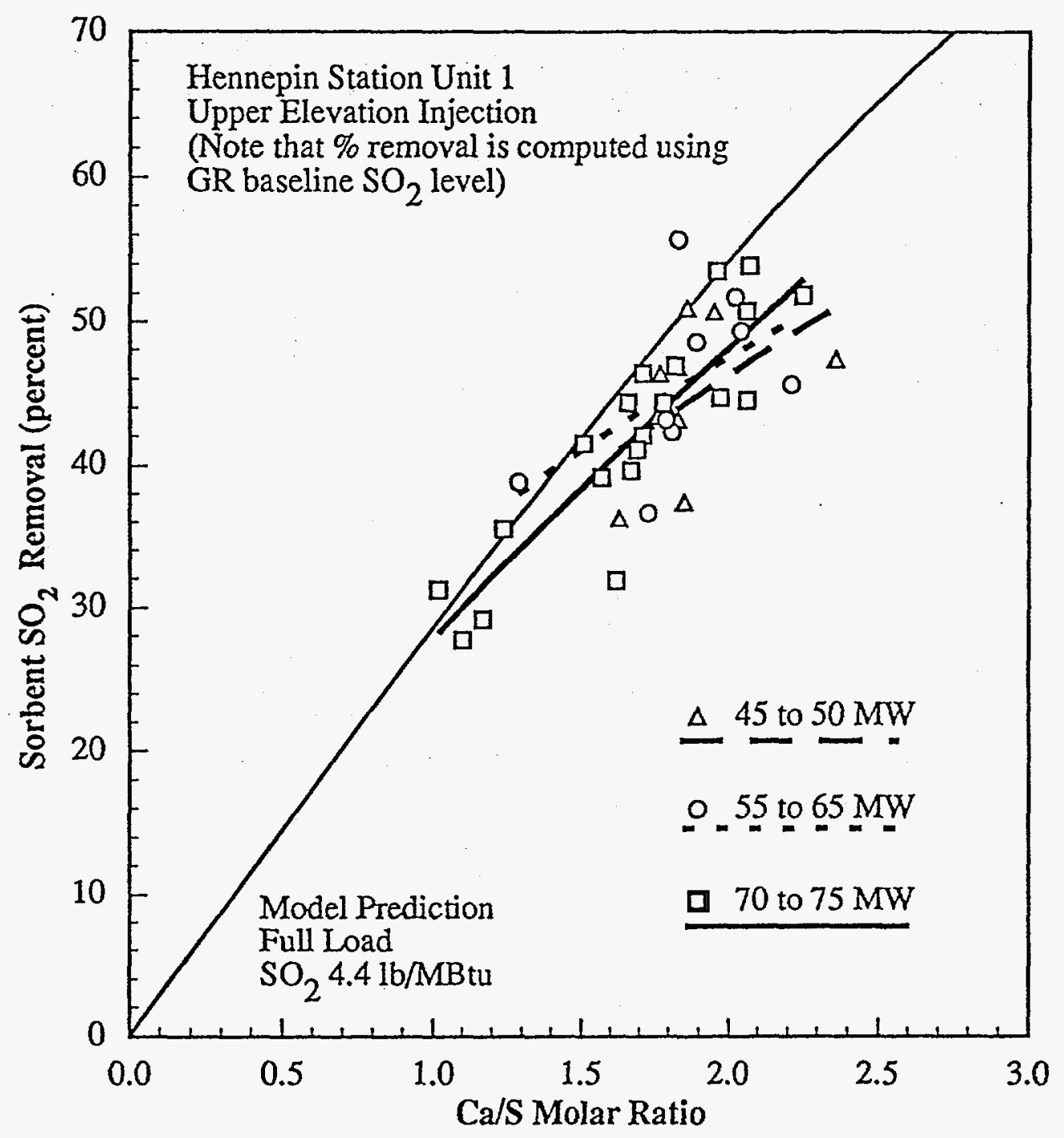

Figure 5-11. $\mathrm{SO}_{2}$ reduction with GR-SI for three load ranges 
the cost of $\mathrm{SO}_{2}$ removal is dominated by the cost of the sorbent itself, the overall cost effectiveness increases with calcium utilization, expressed as the portion of the calcium which is reacted with sulfur. Calcium utilization is calculated as the percentage of $\mathrm{SO}_{2}$ removal divided by the $\mathrm{Ca} / \mathrm{S}$ molar ratio. Figure 5-12 shows the same data as Figure 5-11 re-plotted in terms of calcium utilization. The general trend found was that lower utilizations occur at high $\mathrm{Ca} / \mathrm{S}$ molar ratio. This is consistent with bench scale tests and is caused by blinding of the active $\mathrm{CaO}$ as calcium sulfites/sulfates are formed.

\subsubsection{Injection Configuration}

In computational modeling studies, sorbent dispersion and $\mathrm{SO}_{2}$ concentrations were shown to have a significant effect on $\mathrm{SO}_{2}$ capture efficiencies. Sorbent dispersion is dependent on the penetration and coverage characteristics of the sorbent stream. It can be altered by varying the SI velocity and the injection configuration.

The SI injection system was designed with 6 jets to mix the sorbent uniformly across the furnace ( 4 on the front wall and 2 on the side walls). Figure 5-13 compares the performance in this configuration with that measured when the 2 side wall jets were out of service. Calcium utilization degraded significantly with these jets out of service.

\subsubsection{Effects of Boiler Operation}

Boiler operational parameters were also found to have impacts on the performance of the SI system. Those parameters are:

- Boiler load

- Burner tilt

- Excess air 


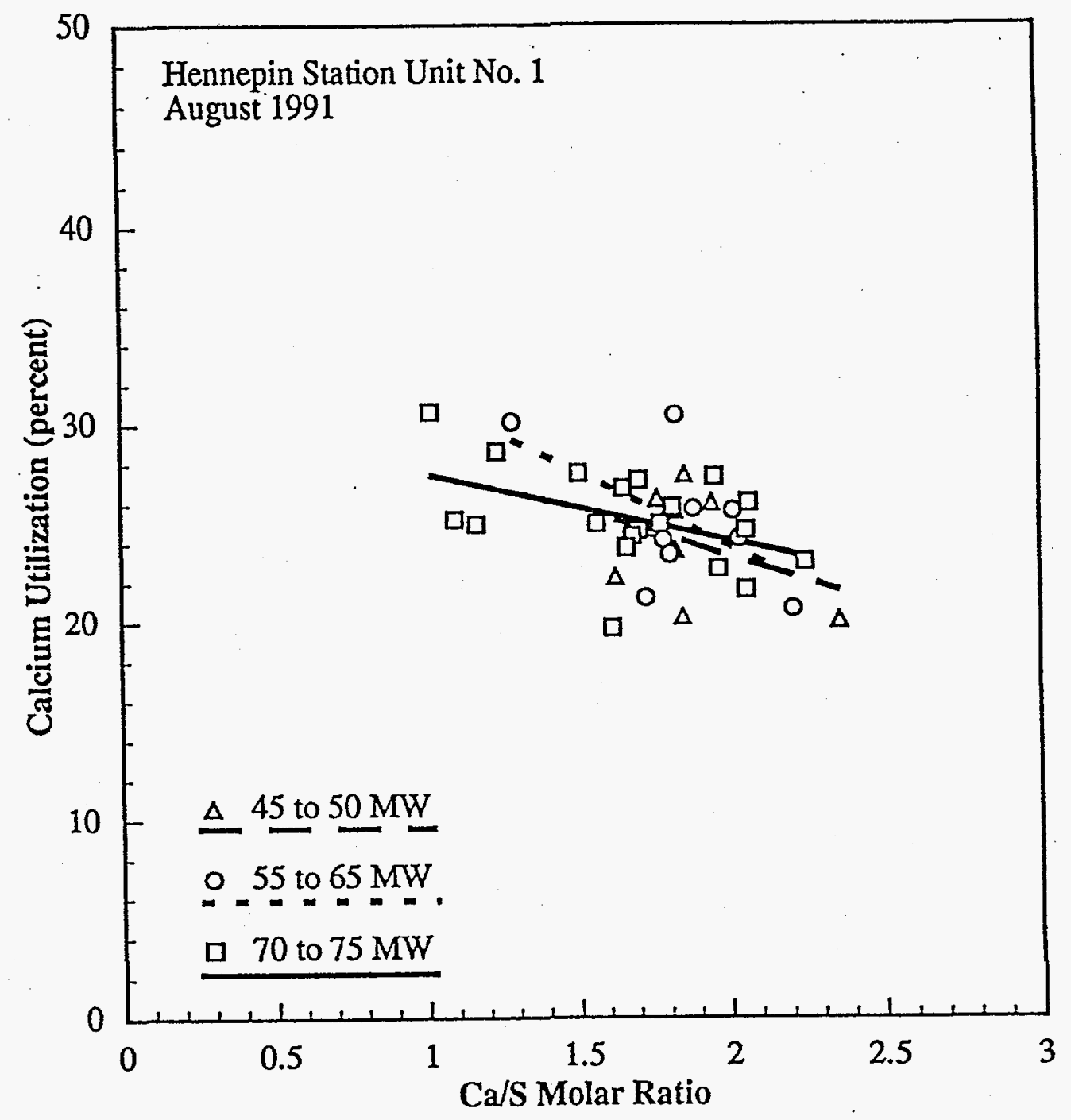

Figure 5-12. Calcium utilization with GR-SI for three load ranges 


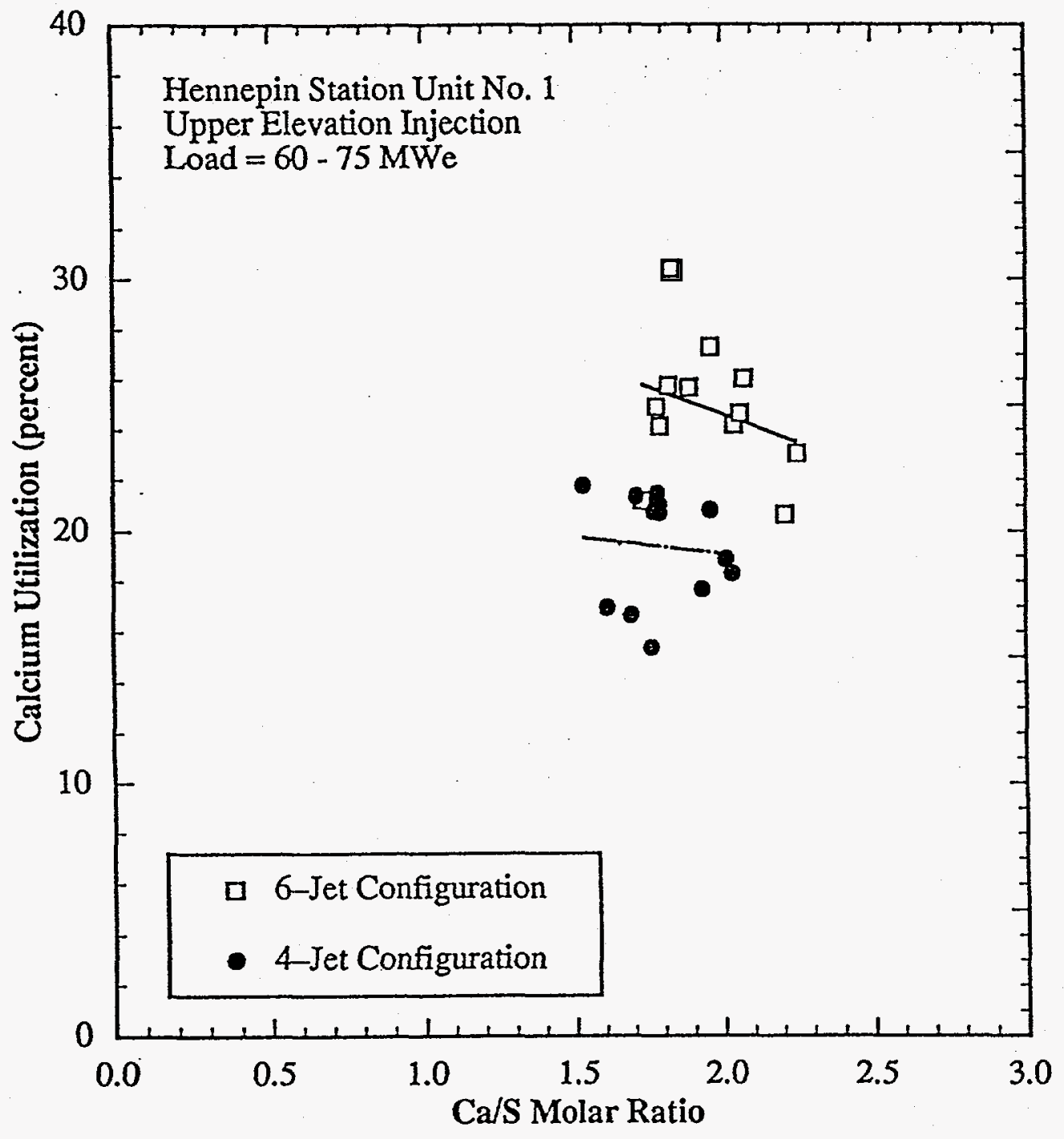

Figure 5-13. Effect of SI jet configuration on calcium utilization 
Boiler Load -As shown above, the $\mathrm{SO}_{2}$ removal goal of the project was consistently achieved at full load using the upper level sorbent injectors. The SI system included a lower set of injectors at the OFA ports for low loads $\left(<45 \mathrm{MW}_{\mathrm{e}}\right)$ when furnace temperatures decreased. Calcium utilization was similar using the upper and lower injectors over the load range.

Burner Tilt Tests at various burner tilt angles were conducted to evaluate the sensitivity of the temperature profile and its effect on sorbent $\mathrm{SO}_{2}$ capture, particularly under lower load operation when burner tilt is adjusted to maintain reheat steam temperature. The midand full-load tests showed calcium utilization to be insensitive to burner tilt angles between -5 to +19 degrees. At low loads $\left(45 \mathrm{MW}_{\mathrm{e}}\right.$ to $58 \mathrm{MW}_{\mathrm{e}}$ ) shown in Figure $5-14$, calcium utilization was significantly affected in tests with burner tilts between -6 and +13 degrees, with the lower level sorbent injectors in service.

Excess Air. The level of excess air had no effect on calcium utilization at full or reduced loads.

\subsubsection{8 $\quad \mathrm{HCl}$ and HF Emissions}

Emissions of $\mathrm{HCl}$ and $\mathrm{HF}$ were also quantified in relatively short tests during baseline and GR-SI operation. Significant reductions in $\mathrm{HCl}$ and $\mathrm{HF}$ emissions due to $\mathrm{GR}-\mathrm{SI}$ were measured. This is due to two processes: replacement of coal with natural gas (natural gas has no chlorine or fluorine) and the reaction of $\mathrm{HCl}$ and $\mathrm{HF}$ with the sorbent [ $\mathrm{CaO}+2 \mathrm{HCl}$ $\rightarrow \mathrm{CaCl}_{2}+\mathrm{H}_{2} \mathrm{O}$ and $\mathrm{CaO}+2 \mathrm{HF} \rightarrow \mathrm{CaF}_{2}+\mathrm{H}_{2} \mathrm{O}$ ). Reductions in $\mathrm{HCl}$ emissions in the range of 60.4 to $85.5 \%$ were measured during GR-SI operation at a gas heat input of 18.5 to $18.7 \%$ and a $\mathrm{Ca} / \mathrm{S}$ molar ratio of 1.64 to 1.66 . Reductions of $\mathrm{HF}$ emissions were in the 94.3 to $99.7 \%$ range. The emissions based on fuel fired were $9.29 \times 10^{-3}$ to $24.6 \times 10^{-3} \mathrm{lb}$ $\mathrm{HCl} / 10^{6} \mathrm{Btu}(3.99$ to $10.6 \mathrm{mg} / \mathrm{MJ})$ and $1.14 \times 10^{-5}$ to $19.1 \times 10^{-5} \mathrm{lb} \mathrm{HF} / 10^{6} \mathrm{Btu}\left(4.90 \times 10^{-3}\right.$ to $\left.82.1 \times 10^{-3} \mathrm{mg} / \mathrm{MJ}\right)$. These may be compared to baseline levels of $6.71 \times 10^{-2} \mathrm{lb} \mathrm{HCl} / 10^{6} \mathrm{Btu}$ 


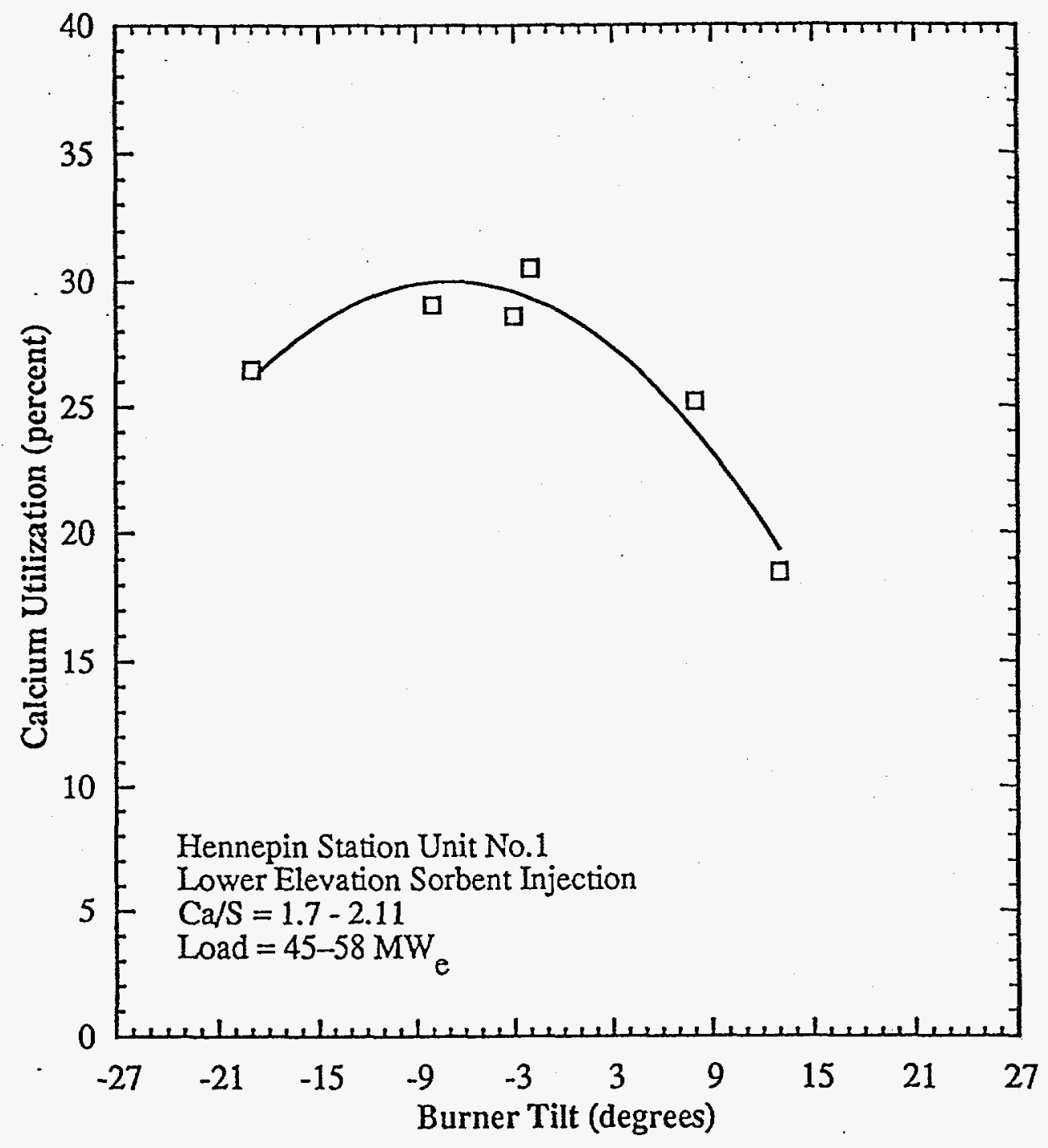

Figure 5-14. Effect of burner tilt on calcium utilization at low load 
(28.9 mg/MJ) and $3.60 \times 10^{-3} \mathrm{lb} \mathrm{HF} / 10^{6} \mathrm{Btu}(1.55 \mathrm{mg} / \mathrm{MJ}) . \mathrm{CaF}_{2}$ and $\mathrm{CaCl}_{2}$ are unstable at temperatures greater than 1150 to $1500^{\circ} \mathrm{F}\left(621\right.$ to $\left.816^{\circ} \mathrm{C}\right)$. Therefore, calcium halide formation must take place after the sorbent has reacted with $\mathrm{SO}_{2}$. Emissions of $\mathrm{HCl}$ and $\mathrm{HF}$ on a yearly basis, with an assumed capacity factor of 32\% (1992 capacity factor = $32.01 \%$ ), would be reduced significantly by the GR-SI operation. $\mathrm{HCl}$ emissions would be reduced to a range of 6 to 22 tons per year ( 5.4 to 20.0 tonne/a) while HF emissions would be reduced to a range of 0.01 to 0.17 TPY $(0.009$ to 0.15 tonne/a). These are compared to baseline emissions of 70 tons $\mathrm{HCl}$ per year (64 tonne/a) and 3.8 tons $\mathrm{HF}$ per year ( 3.4 tonne/a).

\subsubsection{GR-SI Results}

The parametric tests showed that the GR-SI system installed on Hennepin Unit \#1 not only achieved but exceeded the project goals of reducing $\mathrm{NO}_{x}$ and $\mathrm{SO}_{2}$ by 60 and $50 \%$, respectively. Based on the results of the optimization tests, the following GR parameters were set for long term testing and at least a $60 \%$ reduction in $\mathrm{NO}_{x}$ emissions was achieved:

$\begin{array}{lc}\text { Percent Reburning Fuel } & 18 \\ \text { Primary Zone SR } & 1.08 \\ \text { Reburn Zone SR } & 0.90 \\ \text { Burnout Zone SR } & 1.18 \\ \text { Flue Gas Recirculation Flow } & 2,800 \mathrm{scfm}\left(1.32 \mathrm{Nm}^{3} / \mathrm{s}\right)\end{array}$

The following $\mathrm{SI}$ operating parameters were used to achieve a $50 \%$ reduction in $\mathrm{SO}_{2}$ emissions:

Ca/S Molar Ratio

Injection Configuration

Injection Elevation
1.75

6 nozzles

Upper 


\subsection{Lakeside Unit \#7 GR-SI Demonstration .}

A second GR-SI demonstration was completed at City Water, Light and Power's Lakeside Station Unit \#7, located in Springfield, Illinois. Unit \#7 is a $33 \mathrm{MW}_{\mathrm{e}}$ cyclone-fired unit that burns medium to high sulfur Illinois Bituminous coal. The project goals for this demonstration were the same as that for Hennepin Unit \#1, to reduce $\mathrm{NO}_{\mathrm{x}}$ and $\mathrm{SO}_{2}$ by 60 and $50 \%$, respectively.

\subsubsection{GR Results}

The performance of the GR system in controlling $\mathrm{NO}_{\mathrm{x}}$ and its impacts on other gaseous emissions including $\mathrm{CO}$ and $\mathrm{SO}_{2}$ are presented in this section. The program goal was to reduce $\mathrm{NO}_{\mathrm{x}}$ by $60 \%$ at full load. To evaluate the $\mathrm{GR}$ system, parametric tests typically lasting one to two hours were conducted. Each process parameter was varied individually to evaluate its impact independent of the others. The major process parameters relevant to $\mathrm{NO}_{\mathrm{x}}$ control with $\mathrm{GR}$ in this demonstration, that could be varied, included the SR of each zone (primary, reburn, and burnout), reburn fuel injector size, and FGR flow. The baseline $\mathrm{NO}_{x}$ for Lakeside Unit \#7 was $0.97 \mathrm{lb} / 10^{6} \mathrm{Btu}$. This value was used as the base in determining the $\mathrm{GR} \mathrm{NO}$ reductions.

\subsubsection{Zone Stoichiometric Ratios}

The stoichiometric ratios of the three zones significantly impact the $\mathrm{NO}_{\mathrm{x}}$ control process. Limiting the primary (coal) zone SR limits the formation of $\mathrm{NO}_{\mathrm{x}}$ in this high temperature zone. The impacts of the primary and reburning zone stoichiometric ratios at full load are shown in Figure 5-15. The data show that operation at a primary SR of 1.08 and reburning zone SR of 0.83 resulted in the highest $\mathrm{NO}_{x}$ reduction at full load $(67 \%)$, while operation at a primary zone SR of 1.15 and reburning zone SR of 0.90 achieved the target $\mathrm{NO}_{\mathrm{x}}$ reduction of $60 \%$. 
(\%) uo!p๐nрәу xON
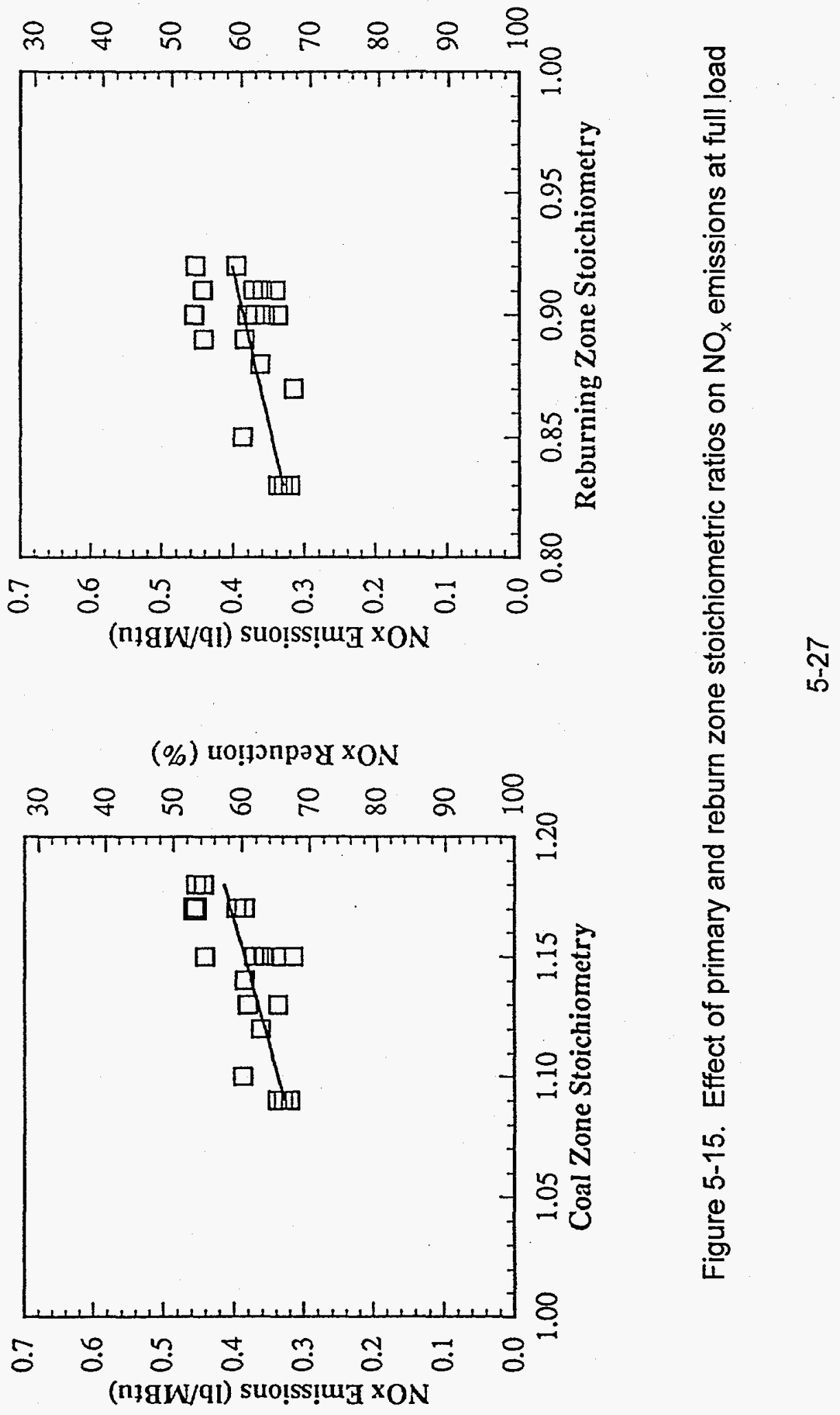
The impact of the burnout (exit)-zone SR on $\mathrm{NO}_{\mathrm{x}}$ and $\mathrm{CO}$ emissions at full load is shown in Figure 5-16 and for mid and low loads is shown in Figure 5-17. Burnout air is used to complete combustion, therefore, lower $\mathrm{CO}$ levels are expected at higher exit zone stoichiometric ratios. At full load, an exit zone SR of 1.20 was expected to achieve fuel burnout. However, in practice an exit zone SR of 1.30 was needed to maintain CO emissions below $200 \mathrm{ppm}$. At mid and low loads, an exit zone SR of 1.35 was required. The exit zone SR has a relatively minor impact on the final $\mathrm{NO}_{x}$ level since the gas temperature at the point of OFA addition is relatively low. At mid and low load, there was no change in $\mathrm{NO}_{x}$ with excess air.

The fly ash carbon obtained during the baseline testing, yielded a range of $2 \%$ to $8 \%$ carbon. Under GR, the fly ash carbon content increased to 12 to $14 \%$ over the range of gas heat inputs of 15 to $25 \%$. At full load, GR had a smaller effect, with fly ash carbon content increasing to 7 to $10 \%$. While in pulverized coal-fired units an increase of $5 \%$ in carbon-in-fly ash results in a $1 \%$ increase in heat loss, for cyclone-fired units where 70 to $80 \%$ of the ash is removed in the cyclone barrels, an increase of $20 \%$ in carbon-in-fly ash results in a $1 \%$ increase in heat loss.

\subsubsection{Reburning Fuel Injector Size}

Two sizes of reburning fuel injectors were tested. The early tests were conducted with large injectors that had relatively low injection velocities. At the completion of several parametric tests, an evaluation of test data was undertaken that included furnace flow modeling. The evaluation showed that improved $\mathrm{NO}_{x}$ reductions should be obtained with smaller diameter injectors. The smaller injectors were installed and used throughout the long-term GR-SI demonstration.

The impacts of injector optimization on $\mathrm{NO}_{x}$ emissions at full and mid load are shown in Figure 5-18. In both cases, the smaller injectors improved $\mathrm{NO}_{\mathrm{x}}$ reduction. This is due to 


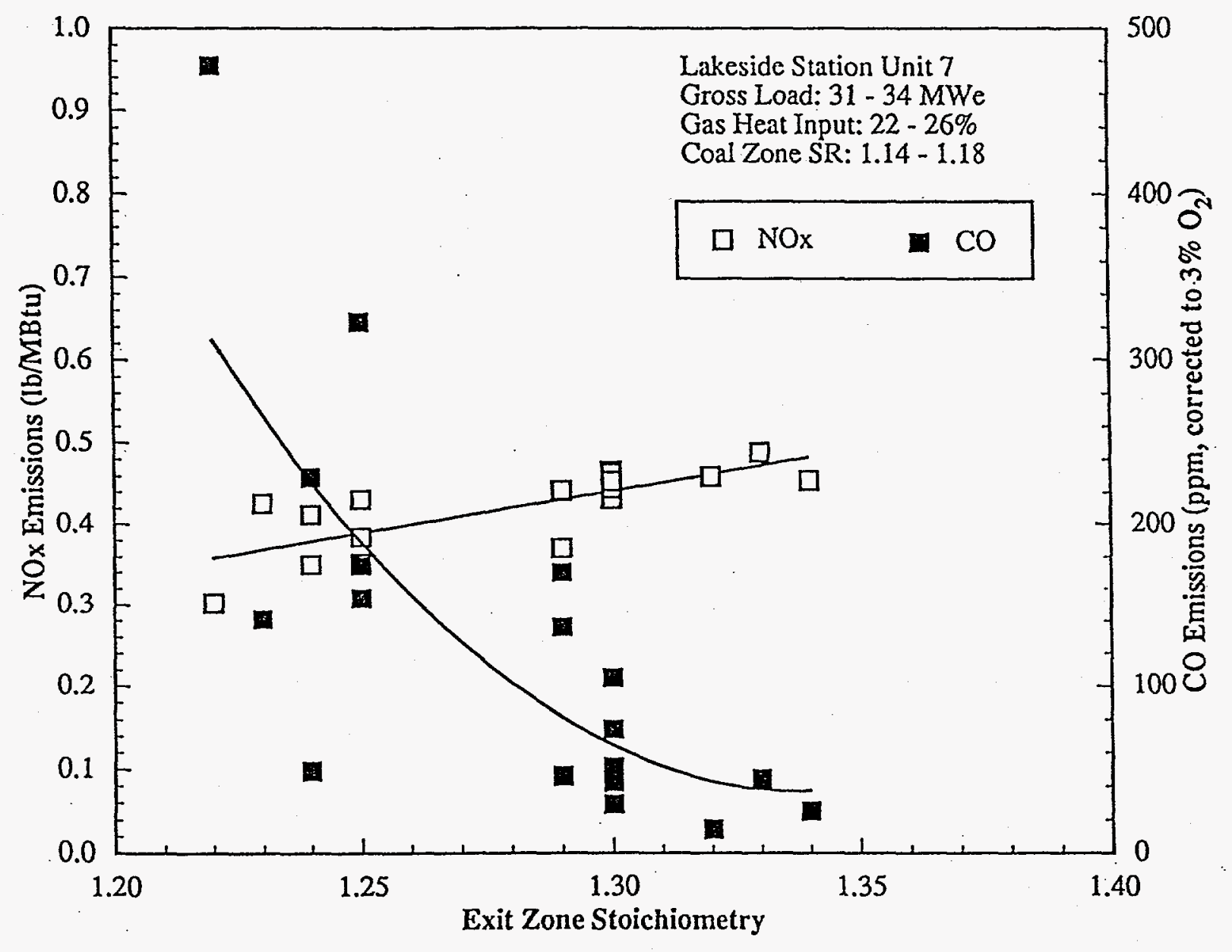

Figure 5-16. Effect of exit zone stoichiometry on $\mathrm{NO}_{x}$ and $\mathrm{CO}$ at full load 


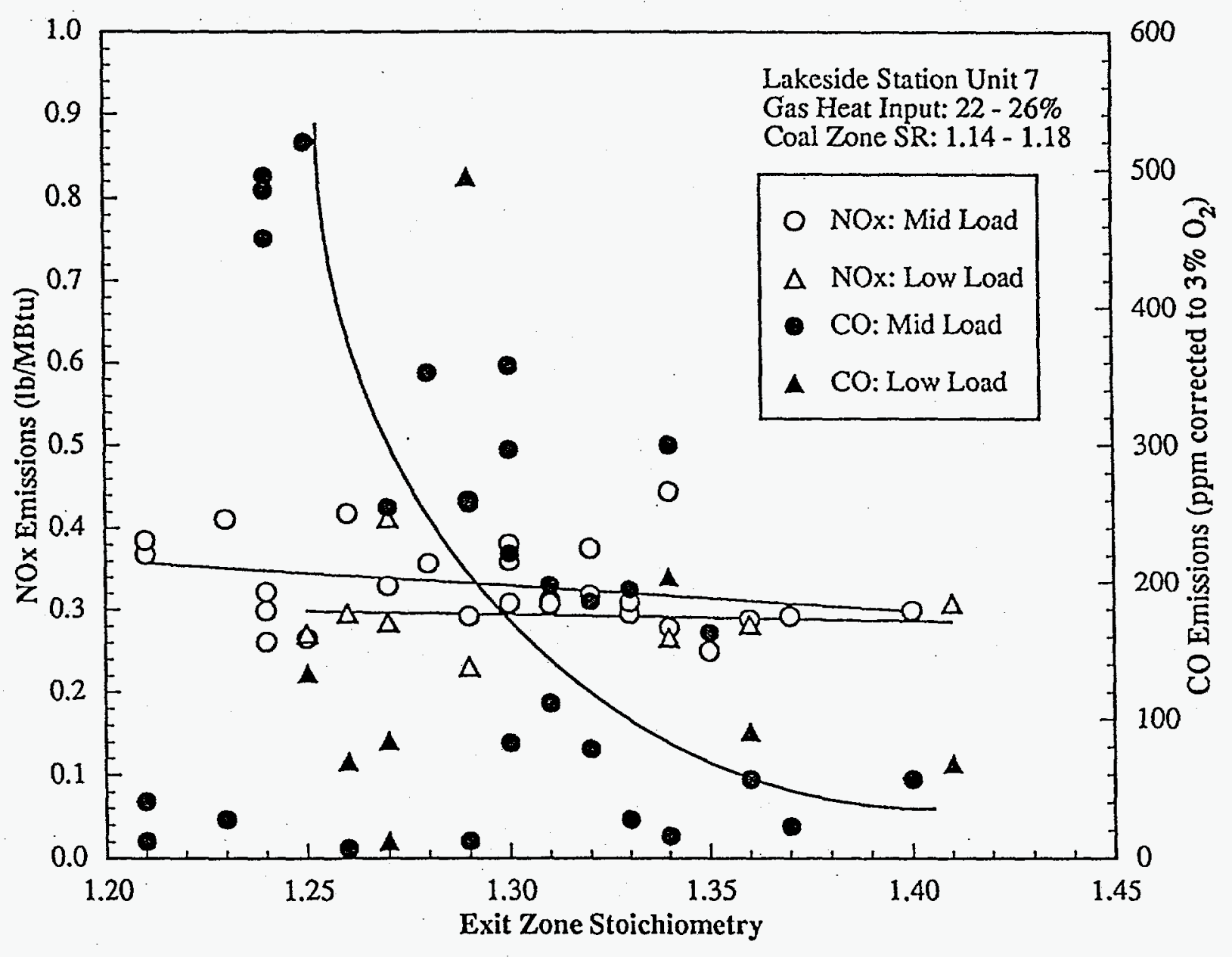

Figure 5-17. Effect of exit zone stoichiometry on $\mathrm{NO}_{x}$ and $\mathrm{CO}$ at mid and low load 


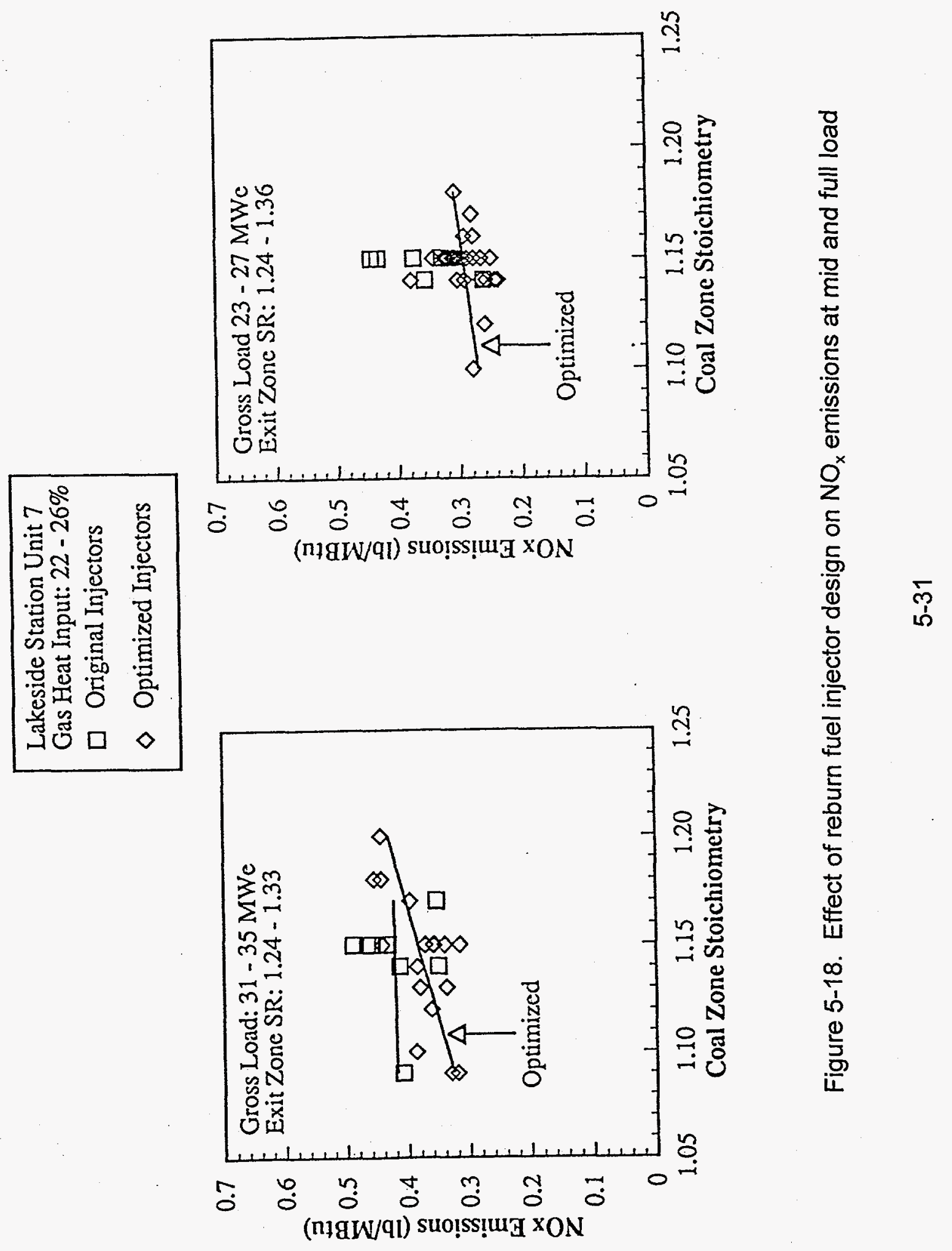


improved reburning fuel jet mixing with the combustion products from the primary zone. On average, $\mathrm{NO}_{\mathrm{x}}$ reductions improved by 3 to $5 \%$ with the smaller reburning fuel injectors.

\subsubsection{Recirculated Flue Gas}

The FGR flow was varied widely, from 3000 to $6000 \mathrm{scfm}$ (1.42 to $2.83 \mathrm{Nm}^{3} / \mathrm{s}$ ). FGR was used as a carrier gas to improve the mass flux of the reburning fuel jets and thereby reduce the mixing time. As expected, higher flows of FGR helped achieve the lowest $\mathrm{NO}_{\mathrm{x}}$ level. This was most clearly the case at low load (19 to $20 \mathrm{MW}_{\mathrm{e}}$ ). The impacts of FGR, expressed as a percentage of total flue gas, at full, mid, and low loads are shown in Figures 5-19 and 5-20. At full load, FGR of 6 to $7 \%$ achieved optimum results, while at mid load 8 to $9 \%$ achieved highest $\mathrm{NO}_{\mathrm{x}}$ reduction, and at minimum load 9 to $10 \%$ was optimum. The reburn zone residence time in this application was only 0.25 seconds, whereas in the Hennepin demonstration it was 0.55 seconds. From comparison of the two demonstrations it is seen that shorter reburn zone residence time units require increased FGR to achieve near optimum NOx reduction.

\subsubsection{SI Results}

The performance of the SI system was initially evaluated with parametric SI-only tests. This was followed by a co-application of both GR and SI technologies over the long-term testing period. The parameters which impact $\mathrm{SO}_{2}$ capture in $\mathrm{SI}$ are the $\mathrm{Ca} / \mathrm{S}$ molar ratio, the SI air flow, and the injection temperature (and indirectly the load). Sorbent characteristics, such as type (hydrate or carbonate) and fineness also impact $\mathrm{SO}_{2}$ capture.

Furnace $\mathrm{SI}$ was developed to achieve $\mathrm{SO}_{2}$ reductions in the 25 to $50 \%$ range. When combined with $\mathrm{GR}$, higher $\mathrm{SO}_{2}$ reductions occur due to coal replacement with natural gas. Limited SI-only testing was characterized to optimize the process. The process was evaluated over the full load range with $\mathrm{Ca} / \mathrm{S}$ molar ratios from 1.0 to 3.0. SI air flows were 


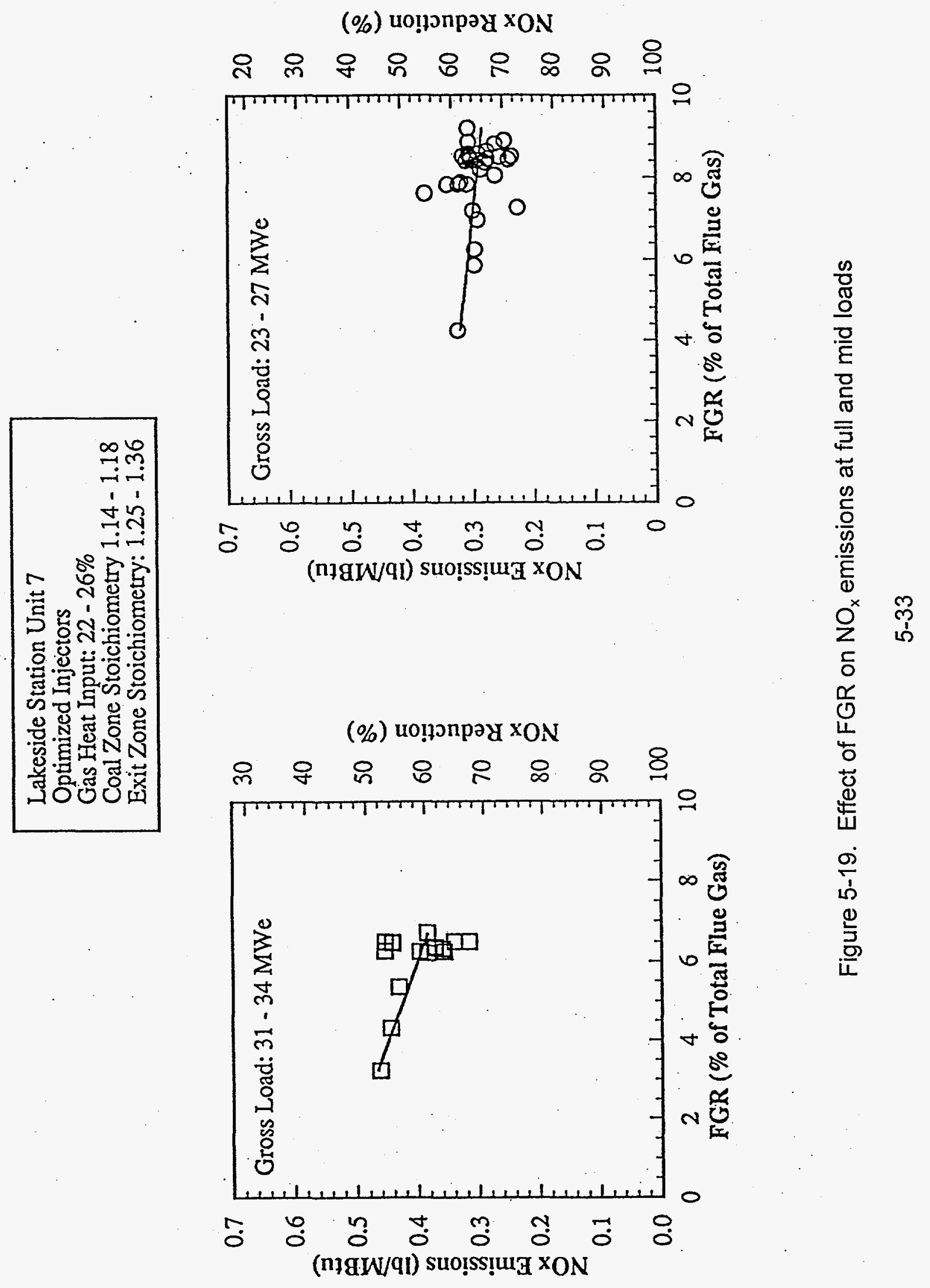


(\%) uo!̣npay $x_{\mathrm{ON}}$

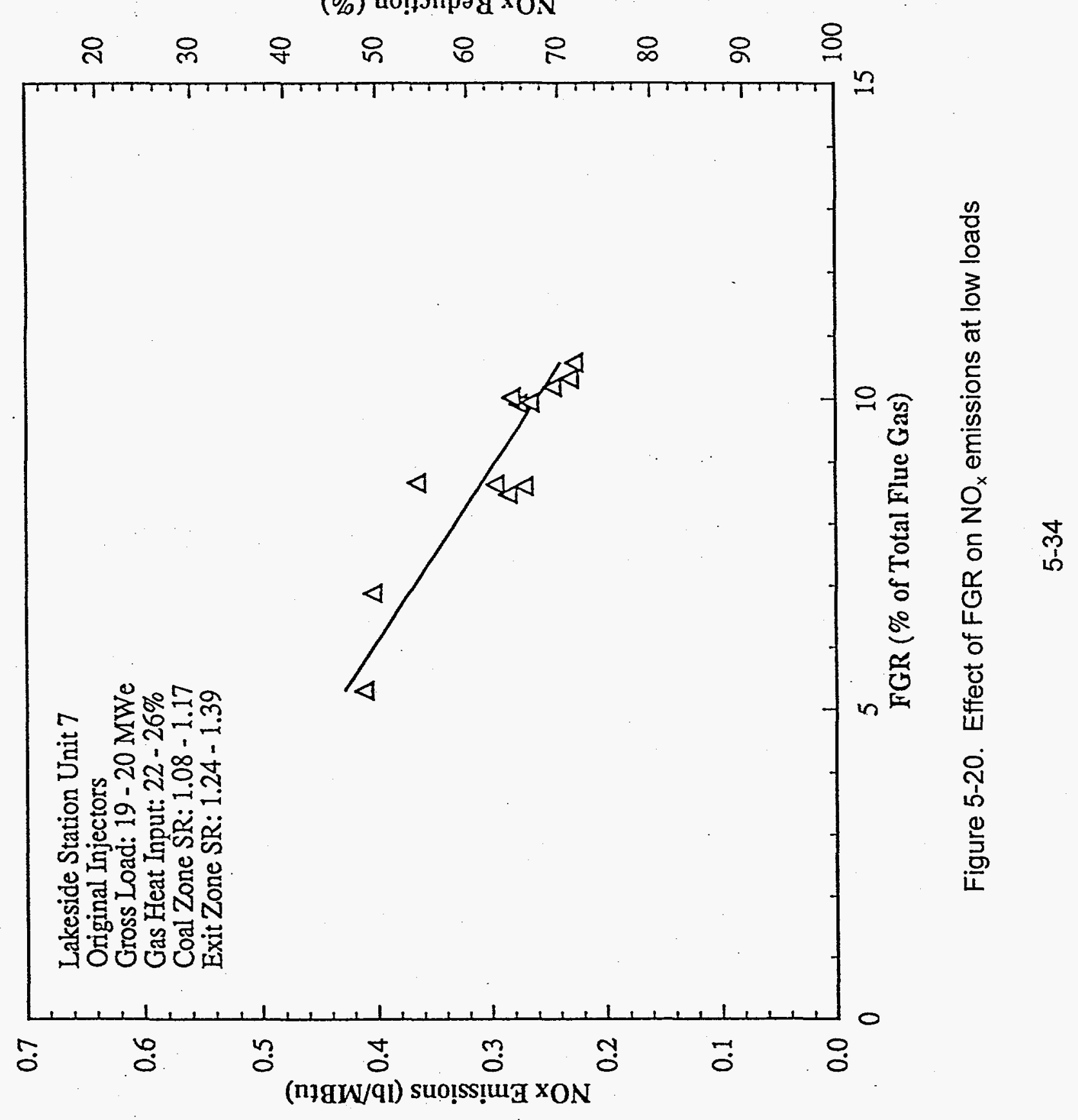


evaluated in the range 1800 to $4600 \mathrm{scfm}\left(0.85\right.$ to $\left.2.17 \mathrm{Nm}^{3} / \mathrm{s}\right)$. Reductions in $\mathrm{SO}_{2}$ were calculated from the $5.9 \mathrm{lb} / 10^{6} \mathrm{Btu}(2540 \mathrm{mg} / \mathrm{MJ})$ baseline.

\subsubsection{Ca/S Molar Ratio}

The $\mathrm{SO}_{2}$ emissions/reductions under $\mathrm{SI}$ operation, for the range of load 19 to $34 \mathrm{MW}_{\mathrm{e}}$, are shown in Figure 5-21. While succeeding figures differentiate data at different loads, on average the $\mathrm{SO}_{2}$ reductions were $25 \%$ at a Ca/S of 1.1 and $42 \%$ at a Ca/S of 2.1 . Figure 5-22 shows the $\mathrm{SO}_{2}$ levels under GR-SI operation with gas heat inputs of 22 to $25 \%$. On average, the $\mathrm{SO}_{2}$ reductions were $51 \%$ at a Ca/S of 1.1 and $61 \%$ at a $\mathrm{Ca} / \mathrm{S}$ of 2.1 . In the majority of GR-SI cases with 22 to $25 \%$ gas heat input the design level of $50 \% \mathrm{SO}_{2}$ reduction, corresponding to $2.95 \mathrm{lb} / 10^{6} \mathrm{Btu}(1270 \mathrm{mg} / \mathrm{MJ})$, was achieved. The maximum $\mathrm{SO}_{2}$ reduction measured under GR-SI was $68 \%$ at a $\mathrm{Ca} / \mathrm{S}$ of 2.09 and gas heat input of $23 \%$.

The injection temperature and indirectly the operating load had strong impacts on $\mathrm{SO}_{2}$ reduction and calcium utilization. While SI was evaluated with parametric tests over a wide range of $\mathrm{Ca} / \mathrm{S}$ molar ratios, full load GR-SI operation was generally conducted with $\mathrm{Ca} / \mathrm{S}$ in the 1.5 to 2.0 range. The data show that sorbent $\mathrm{SO}_{2}$ capture was 4 to $6 \%$ higher when GR was applied with SI. GR resulted in an upward shift in the gas temperature, at the sorbent injection planes, to provide for a more suitable temperature for $\mathrm{SO}_{2}$ capture. The corresponding $\mathrm{Ca}$ utilizations are shown in Figure 5-23. SI, with hydrated lime, generally results in a Ca utilization in the 20 to $30 \%$ range. That was the case in this application. On average, a 1.5 to $2.5 \%$ increase in Ca utilization resulted from GR-SI operation over levels for SI-only operation under full load. However, at reduced loads the impact of GR on the $\mathrm{SO}_{2}$ capture process was more significant. 


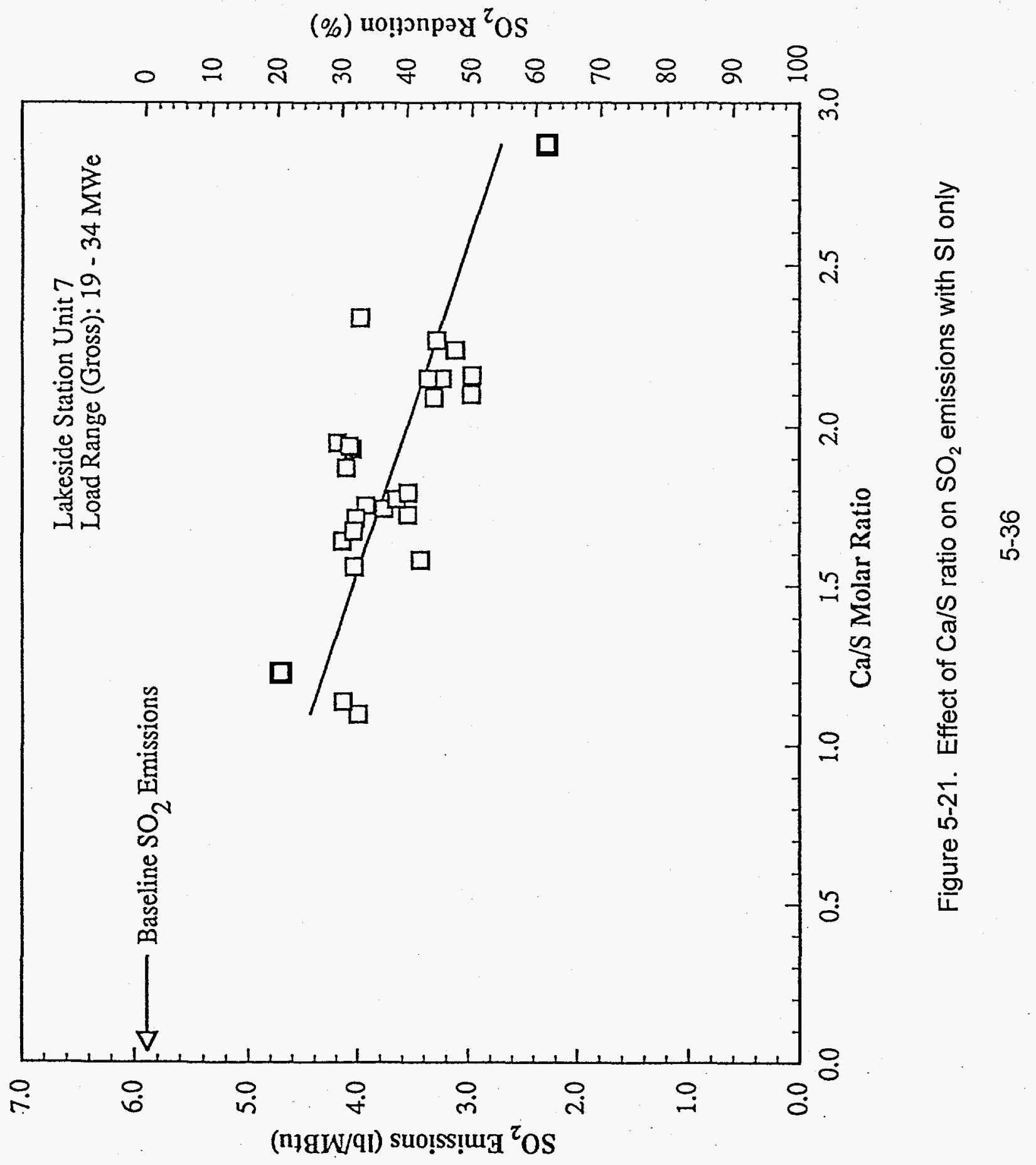




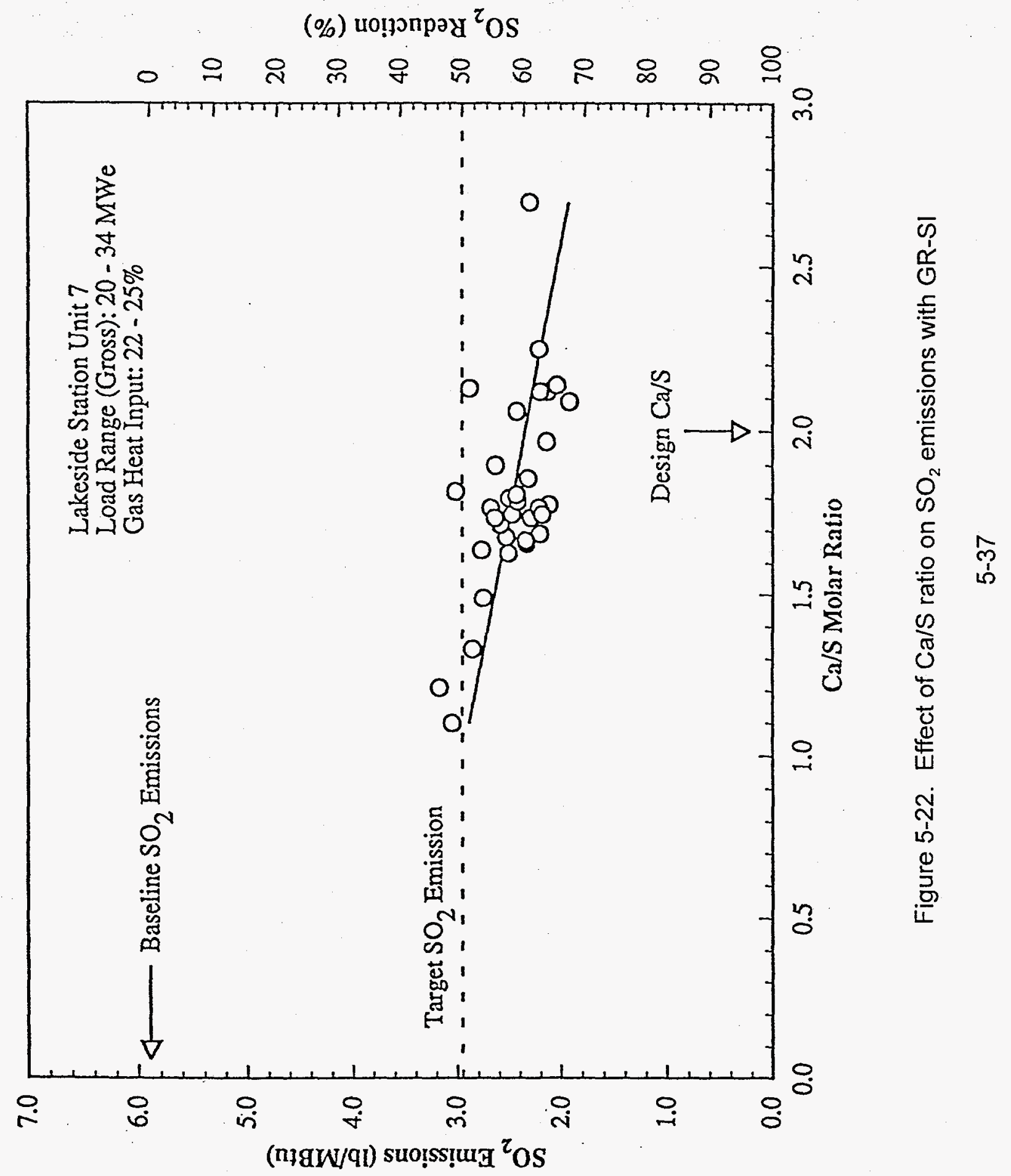




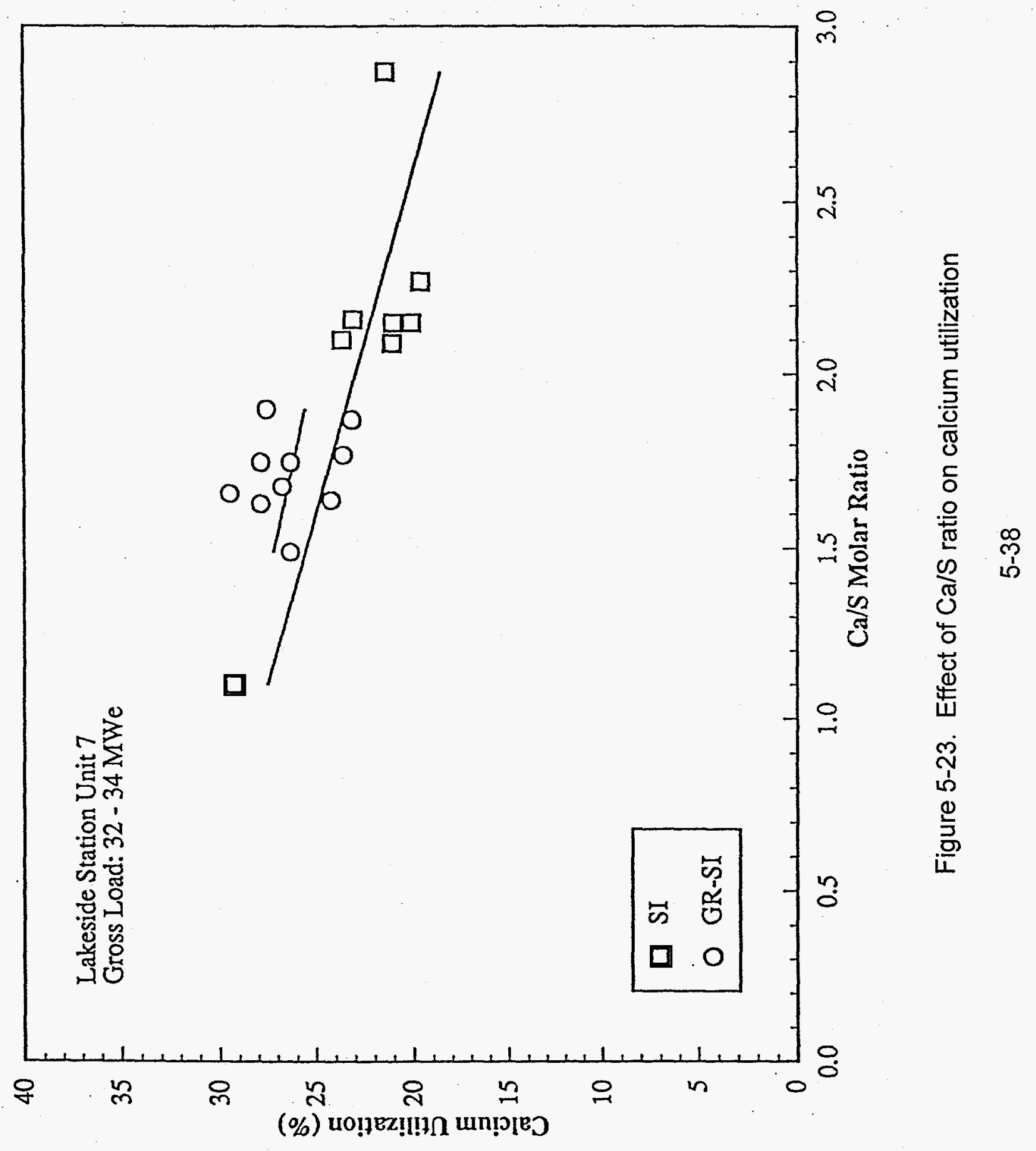




\subsubsection{2 - - Sorbent Injection Air Elow}

SI air was used to increase the mass flux of sorbent jets and thereby enhance mixing. Since the process is temperature dependent, rapid mixing with the flue gases at the exit of the furnace must take place, otherwise a loss in process efficiency results. Figure 5-24 shows $\mathrm{SO}_{2}$ emissions under GR-SI and SI-only operation at full load, for a range of $\mathrm{SI}$ air flows. Modest reductions in $\mathrm{SO}_{2}$ emissions were measured at high $\mathrm{SI}$ air flows. Under $\mathrm{GR}-$ $\mathrm{SI}$, the $\mathrm{SI}$ air flow of $3700 \mathrm{scfm}\left(1.75 \mathrm{Nm}^{3} / \mathrm{s}\right)$ was commonly used and optimum results were achieved with $4600 \mathrm{scfm}\left(2.17 \mathrm{Nm}^{3} / \mathrm{s}\right)$.

\subsubsection{GR-SI Results}

The $\mathrm{NO}_{x}$ and $\mathrm{SO}_{2}$ reductions measured with $\mathrm{GR}-\mathrm{SI}$ during long term testing are shown in Figure $5-25 \mathrm{a}$ and $5-25 \mathrm{~b}$. The target reductions of $60 \%$ for $\mathrm{NO}_{x}$ and $50 \%$ for $\mathrm{SO}_{2}$ are also shown. Generally, gas heat inputs of 22 to $24 \%$ were used, which approximate the design level of $24 \%$, and the $\mathrm{Ca} / \mathrm{S}$ ratio was in the range of 1.5 to 1.9 at full load and 1.9 to 2.1 at reduced load. On average, the $\mathrm{Ca} / \mathrm{S}$ ratio during long-term testing was below the design level of 2.0. Over the long-term testing period, $\mathrm{NO}_{x}$ reduction averaged $63 \%$ and $\mathrm{SO}_{2}$ reduction averaged $58 \%$.

\subsection{GR-SI Technology Conclusions}

Based on the nitrogen oxide and sulfur dioxide reductions achieved on the tangentiallyfired unit and cyclone-fired unit demonstrations, it is seen that the GR-SI technology is equally applicable to these two types of utility boilers. In both demonstrations, the NOx and $\mathrm{SO}_{2}$ reduction goals were achieved within the predicted operating parameters to achieve such reductions. 


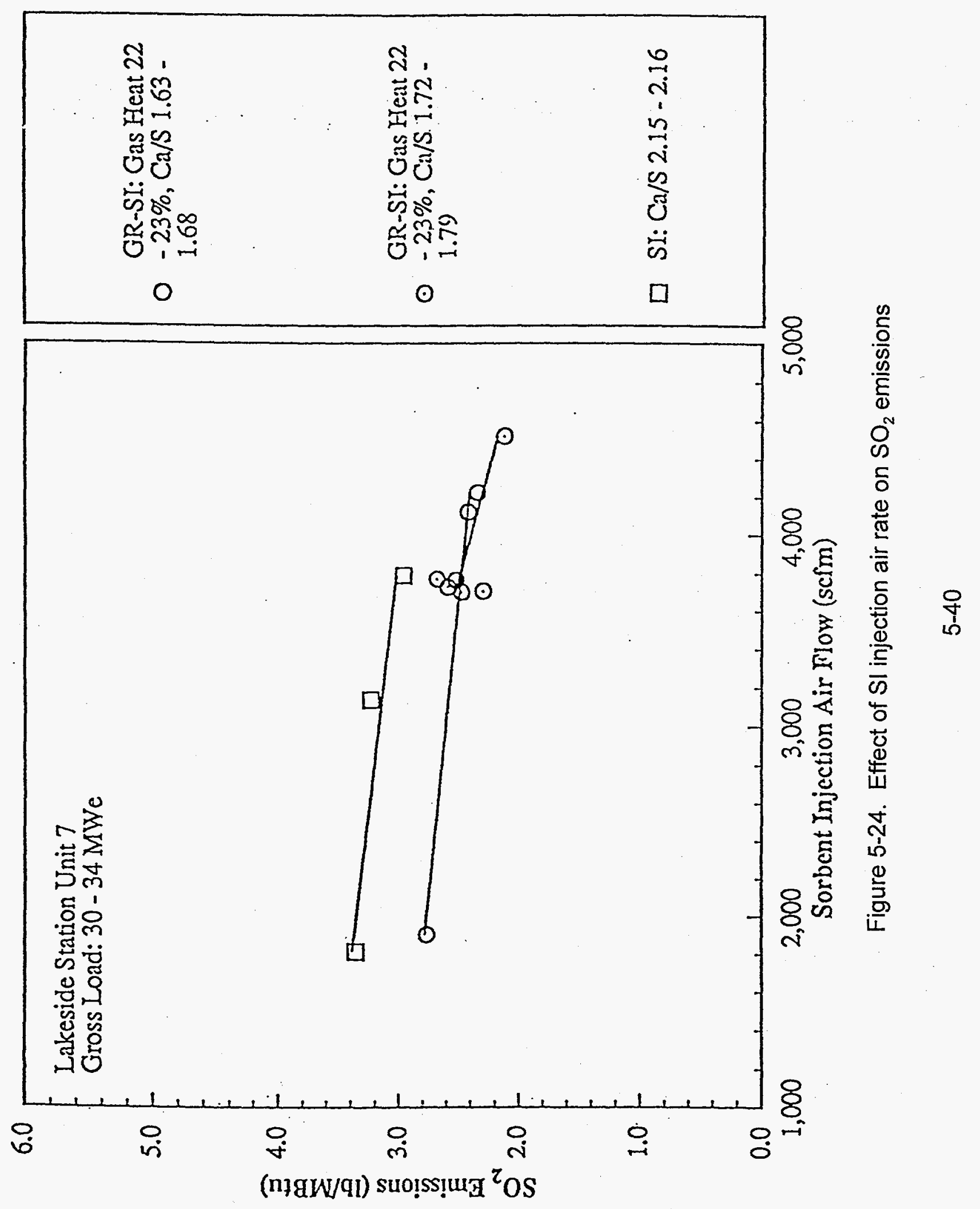




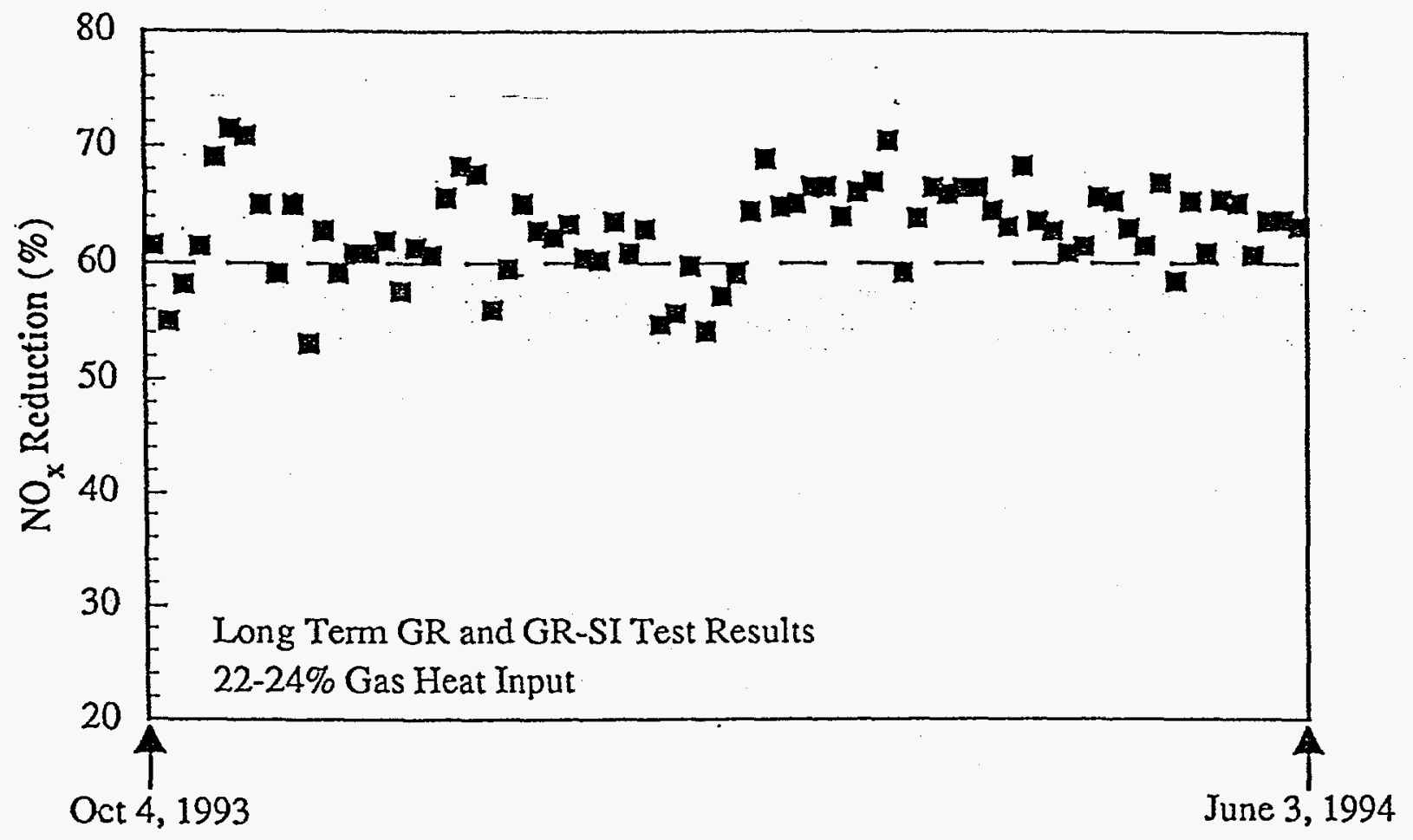

Figure 5-25a. Long term testing $\mathrm{NO}_{x}$ emissions reduction

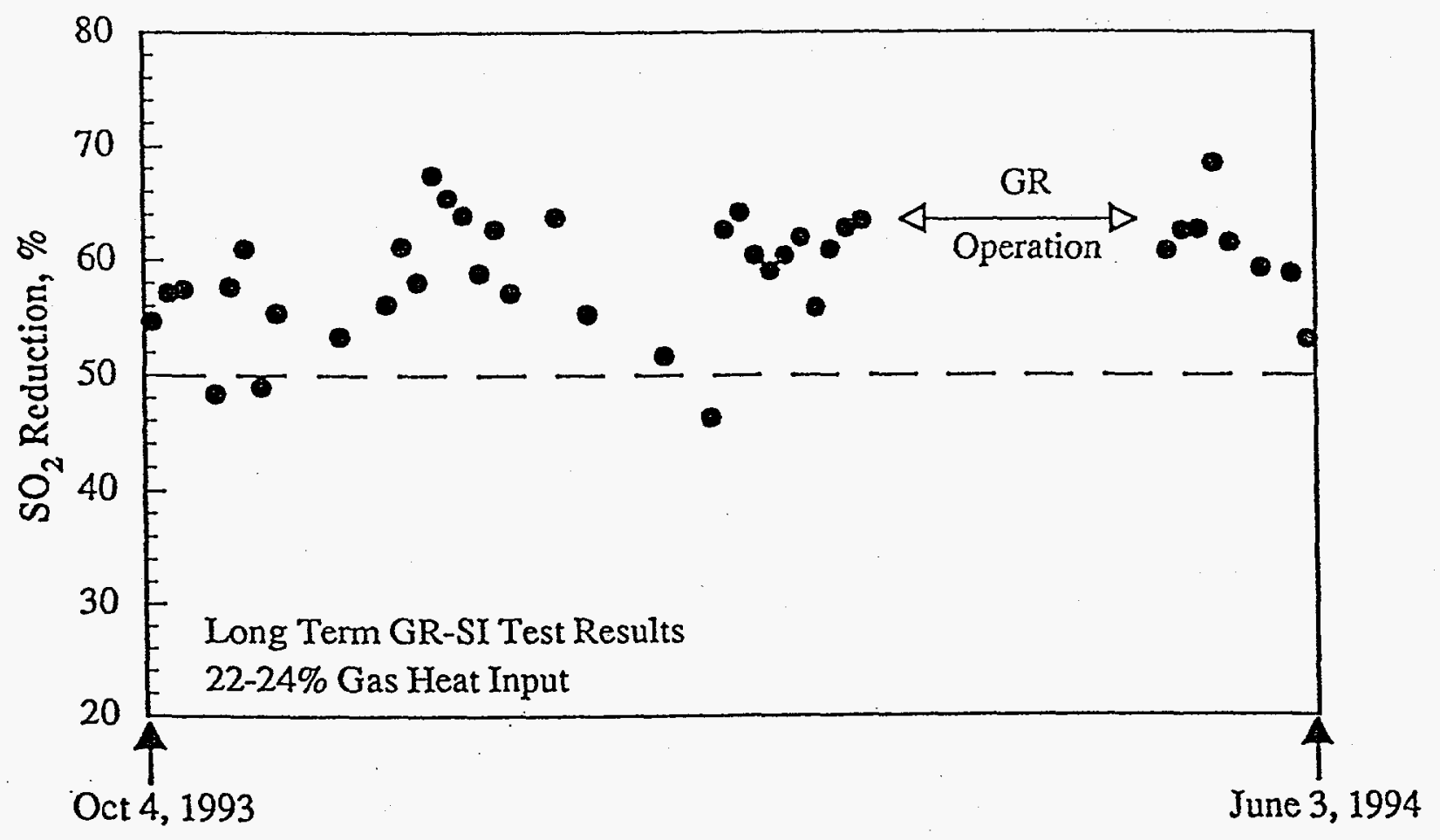

Figure 5-25b. Long term testing $\mathrm{SO}_{2}$ emissions reduction 


\subsection{BOILER IMPACTS}

\subsection{Operational Impacts}

\subsubsection{Thermal Performance}

In this section the impacts of GR and SI operation on boiler thermal performance are discussed. In steam generating units, the heat released from combustion of fuels must be absorbed by heat exchangers with high efficiency. These include the furnace waterwall, the secondary superheater, primary superheater, generating bank, and air heater. Elevated steam temperature and pressure are preferred since they result in the lowest heat rate. The unit must operate with minimum deposition of ash on the furnace waterwall and convective heat exchangers.

GR operation can affect the thermal performance of the unit in two ways. First, GR affects the furnace heat release profile and second, GR operation changes local stoichiometric ratios and particulate loading resulting in minor changes in lower and upper furnace deposition patterns. Demonstrations of the technology showed that the overall impact of GR operation on the heat absorption profile was very minor. At full load a small decrease in furnace water wall heat absorption and small increases in heat absorption in the convective heat exchangers were calculated. At lower loads, data showed an increase in furnace heat absorption and small reductions by convective heat absorption. There will be a reduction in thermal efficiency of approximately $1 \%$ due to dry gas heat loss, moisture in fuel heat loss, and heat loss due to moisture from combustion. The decrease in heat absorption and the resulting rise in the flue gas temperature increase the dry gas heat loss. Fuel switching, i.e. replacement of coal energy with energy from natural gas, results in a reduction in the fuel moisture heat loss. Since natural gas has a higher hydrogen-tocarbon ratio than coal, its combustion results in formation of more moisture. Consequently there is a higher moisture loss. 
During SI operation, there is an increase in heat absorbed by the furnace and reductions in convective heat absorption due to sorbent fouling, especially in the generating bank. Sootblowers must be used almost continuously in order to remove the deposits and maintain steam temperatures near the design point and limit upward excursions of flue gas temperature. The increased particulate loading caused a shift in heat absorption from the furnace and upper convective pass to the convective backpass. This shift has the following impacts:

- Reduction in thermal efficiency (approximately $1.2 \%$ )

- Increase in temperature and velocity of the flue gas

- Higher fly ash resistivity, which has been found to vary strongly with temperature, thus potentially reducing the collection efficiency of the ESP

In tangentially-fired boilers, three systems are used to control superheat and reheat steam temperatures as load, excess air, boiler fouling, and other parameters vary. These include:

- $\quad$ Burner Tilt Burner tilt adjusts the position of flames in the furnace. When the burners are tilted up, furnace waterwall heat absorption is reduced shifting heat to the superheater and reheater sections to increase the main and reheat steam temperatures. Under normal operation, the burner tilt is controlled automatically to achieve the reheat temperature set point.

- $\quad$ Reheat Attemperation Feedwater is sprayed into the reheat steam for further reheat temperature control. Since the attemperation water bypasses the high pressure turbine stages, it increases heat rate (reduces thermal efficiency). Accordingly, the reheat attemperation is normally used as a backup system.

- Main Steam Attemperation Feedwater is also sprayed into the superheat steam to control its temperature. This provides a means to adjust superheat steam temperature independent of reheat steam temperature, which is controlled primarily by burner tilt. 
Fouling of the reheater, caused by SI operation, requires higher burner tilts to maintain reheat temperature. Also, additional superheat steam attemperation is required to control the main steam temperature. Only very low levels of reheat attemperation are required.

\subsubsection{Slagging}

Specific areas of the boiler have the potential for increased slagging under GR-SI operation due to the following:

- The slightly lower primary zone stoichiometric ratios and resulting higher gas temperature in that zone could exacerbate slagging in the lower furnace

- The reducing conditions in the reburning zone could promote slagging in this zone.

Demonstrations of the technology have shown that GR-SI operation does not exacerbate slagging in the furnace. Some buildup of slag in the lower furnace, from the top burner elevation to the OFA ports, can occur, but in not excessive levels as compared to that under baseline operation. Most of the deposits below the nose elevation were small deposits of fine ash particles which most likely consisted of particles with a very low melting point. The small molten particles impinge on the tubes and tend to resolidify as they come in contact with the relatively cooler wall. Little change in the upper furnace slagging was observed.

Since ash fusion temperatures are lower under reducing conditions, areas in the furnace that are deficient in excess air may have increased slag buildup. Sootblowing more frequently or with greater effectiveness (i.e. higher pressure) may be required to reduce slag buildup. 
Injection of natural gas and-FGR promote formation of slag patterns, i.e. slag accumulations around the nozzles forming "eyebrows" and on the waterwall areas above the natural gas/FGR injectors. Ash accumulation at the port entrances may be attributed to the tempering caused by the injection of gas and FGR and the fuel-rich conditions in the reburning zone. Periodic manual cleaning (nominally weekly) is sufficient to maintain normal GR operation. Ports should be thoroughly cleaned after periods when the GR system is out of service.

\subsubsection{Convective Pass Fouling}

As stated previously in this report, GR results in an increase in flue gas temperature in the upper furnace due to heat input above the primary zone. Steam temperatures, however, are controlled through steam attemperation. SI increases the particulate loading which tends to foul the tubes. However, this is offset by increased frequency of sootblowing. In tangentially-fired boilers, with the burner tilt capability, a cyclical pattern results. At full load, coal burners are initially tilted downward. As tubes begin to foul when $\mathrm{SI}$ is introduced, the burners tilt upward to compensate for the reduction in heat absorption. Sootblower operation rectifies the situation and the burners return to the downward position.

Demonstrations of the technology have shown that during GR-SI the heat absorption ratio (HAR) and cleanliness factors can be maintained at near baseline conditions thru frequent use of sootblowing. The HAR for the secondary superheater varied most widely but was maintained. Very little change was noted in the reheater. However, higher flue gas temperatures were observed in the primary superheater due to increased levels of fouling. Steam temperatures were maintained during GR-only operation by using steam attemperation. 


\subsubsection{Auxiliary Power}

The major contributors to increases in auxiliary power requirements are the following:

- $\quad$ FGR fan

- SI air fan

- Injector cooling air fans

- Sorbent transport equipment

- Electrostatic precipitator (handling increased particulate)

For boilers less than $100 \mathrm{MWe}$, the increased power requirement will be $700-1000 \mathrm{~kW}$.

\subsubsection{Cooling Requirements}

Retrofit of a GR-SI system includes installation of several furnace wall openings. Components in these openings that are not water cooled require protection from the hot furnace gases. These include openings for natural gas, OFA, and sorbent. During GR-SI operation these components are cooled by the input gases. Natural gas cools the reburning nozzles, OFA cools the OFA nozzles, and sorbent injection air cools the SI nozzles.

During non GR-SI operation a protective cooling air blanket is directed to and through the GR-SI furnace wall openings to provide the required protection from the hot furnace gases. The protective blanket for the overfire ports uses a small amount of hot secondary air that passes through the OFA control dampers. The dampers have a minimum open position which assures enough air passage to give a velocity of $50 \mathrm{ft} / \mathrm{sec}$ or greater through the ports. Cooling fans are used to cool the natural gas and SI injectors. 


\subsection{Durability}

A high number of equipment items in the plant are subject to mechanical wastage from using coal as the primary fuel, particularly the process and delivery systems. These include feeders, mills, primary coal/air transport lines, coal nozzles in burners, convective pass, electrostatic precipitator, stack, and bottom ash systems. Surface wastage (erosion) exists on boiler parts that are exposed to particulate from combusted coal and sootblowing. During GR, approximately $10-20 \%$ of the coal fuel is replaced by natural gas. The use of gas allows for a corresponding reduction in coal usage, reducing the mechanical wastage on equipment. Also, since natural gas has no particulate or ash residue, the decreased use of sootblowers and lower level of particulate provides a proportional benefit to tube life expectancy.

\subsubsection{Boiler Tubes}

During reburning, a fuel-rich condition is established in the reburning zone. It is well known that fuel-rich conditions can enhance tube wastage due to two mechanisms:

- When fuels containing sulfur are burned under oxygen deficient conditions, some of the sulfur forms reduced sulfur species such as COS and $\mathrm{H}_{2} \mathrm{~S}$. These species react with iron in the tubes via $\mathrm{Fe}+\mathrm{H}_{2} \mathrm{~S}=\mathrm{FeS}$. The FeS scales off the tube leading to wastage (corrosion).

- Under normal excess air operation, the tubes are protected by a thin oxide layer. Reducing conditions, particularly fluctuating (oxidizing/reducing) conditions, can continuously degrade this protective layer.

Normal rates of tube wastage in coal-fired boilers are in the range of 0.001 " to 0.003 " per year, while some boilers inherently produce massive tube wastage. During the two field demonstrations described above, a one-year load-following long term test program was conducted. Data obtained following the test period provided an initial indication of the potential for significant tube wastage. 
During field demonstrations performed by EER, the boiler tubes were subjected to both destructive and non-destructive testing to determine if GR operation jeopardizes the life of the tubes. Specific areas were targeted where the mechanisms listed above suggest the potential for significant tube wastage. The goal of the testing was first and foremost to determine if there was a significant increase in tubewall wastage from the planned one year of operation. This would be readily apparent using the testing methods prescribed. A secondary goal was to determine the incremental change in tube thickness and project this change to the end of the boiler useful life. Since the nominal tube wastage rates are small, a statistical approach was warranted. It should be noted that extrapolating small tube wastage differences over a large time period can be considered questionable. However, significant levels of tube wastage over a short period can be used to provide long-term predictions.

Boiler tubes must be of suitable metallurgical quality to withstand the severe conditions encountered in the boiler environment. Thus it was necessary following GR to test the boiler tubes and determine if any changes to the metallurgy had occurred. Tube samples, physically extracted from the boiler both prior to and after GR operation, were tested for microstructures, Rockwell B Hardness and sulfur print. A comparison was then made between the results of the two sets of tube samples to determine if any metallurgical changes occurred, such as overheating, thermal-fatigue cracks, grain-boundary oxidation, corrosion, and pitting.

Following extensive statistical evaluation, it was concluded that:

- No significant tube wastage was found.

- Levels of non-GR tube wastage measured did not compromise the projected life of the boiler.

- No metallurgical degradation was found. 
During demonstrations of the technology, no adverse conditions in the air heater were noted as a direct result of GR-SI operation. However, SI requires an increase in sootblowing which may have a degrading effect on the air heater from the excessive dwell time of the sootblower lance at its innermost position. It is recommended that wear plates be installed at the inboard extent of the sootblower travel to protect the basket elements.

\subsubsection{Electrostatic Precipitator}

The level of particulate produced in the boiler decreases proportionally to the amount of natural gas used during reburning. However, a marked increase occurs during SI. For this reason it was necessary to perform an evaluation of the ESP prior to installation of SI to verify that it had sufficient capacity to handle the increase.

If particulate emissions are found to be excessive, control can be achieved by incorporating a humidification system. This equipment will enhance the effectiveness of the ESP thereby limiting particulate emissions to near baseline levels. By cooling the flue gas and adding moisture, the resistivity of the particles is decreased making the particles more receptive to capture in the ESP. It is necessary to control fouling of the tubes using the sootblowing system in order to maintain a flue gas temperature that is compatible with the humidification system. Fouling will cause the flue gas temperature to rise and reduce the effectiveness of the system.

During demonstrations of the GR-SI technology, no physical damage was found to occur in the precipitators. However, it is recommended that the utility maintain a preventive maintenance program. In addition, the rapping sequence should be optimized to avoid ash buildup. 


\subsection{ECONOMICS}

The capital and operating costs for the $\mathrm{GR}$ system for $\mathrm{NO}_{\mathrm{x}}$ emissions reduction and the $\mathrm{SI}$ system for $\mathrm{SO}_{2}$ emissions reduction are based on a retrofit of a $300 \mathrm{MWe}$ coal cyclonefired power plant. The reason for selecting a cyclone-fired unit is that there are not many low cost NOx control options for these type of units. The degree of complexity regarding retrofit costs were factored based on the retrofit costs for the GR-SI demonstrations completed under this DOE contract. Separate capital and operating costs are presented for the GR and the SI systems. These two systems were treated as separate technologies; the only major synergistic effect of the GR system on the $\mathrm{SI}$ system is the reduction of $\mathrm{SO}_{2}$ based on the replacement of sulfur-containing coal with natural gas devoid of sulfur.

\subsection{Gas Reburning System}

\subsubsection{GR - Economic Parameters}

The capital cost estimates presented summarize major equipment cost, approximate bulk material take-offs, and installation labor to arrive at direct construction costs. Construction indirects are added which include: field supervision, construction overhead and fee, and freight. In addition, costs for detailed engineering, project management, procurement, construction management, start-up, and contingency are included to develop the total installed system cost. All engineering and construction costs are representative of a turnkey contract arrangement. EER considers these estimates to be Class II, Preliminary Estimates. The estimates are expected to be representative of the actual cost $-10 \% /+15 \%$. This is based on the information available at this time which includes preliminary process design and conceptual engineering completed, recent major equipment quotes, bulk material takeoff's and average expected labor rates and productivity. 
This section-provides the basis for the estimating procedures, along with a list of assumptions used for estimating installation manhours and costs. The cost estimates have been developed using the following sources of information for equipment pricing and for the development of labor costs:

- Richardson's Rapid System 1993 edition of Process Plant Construction Estimating Standards

- Questimate Cost Estimating software by Icarus Corp.

- Means Electrical Cost Data 1991 edition

- Vendor Quotations for Major Equipment

- $\quad$ EER's database of previous equipment purchases

Data from all of these sources were summarized using EER cost estimating software. Once the direct costs were determined, costs for field supervision, contractor overhead and fee, freight, engineering, project management, construction management, start-up, and contingency were added to determine the total installed cost.

\subsubsection{GR - Estimated Process Capital Cost}

The design of the GR system included three integrated systems: 1) natural gas injection, 2) FGR, and 3) OFA injection. Natural gas is mixed with FGR at the gas injection nozzles located above the cyclone barrel re-entrant throats. A natural gas header was assumed to exist at the station and a tie-in was made to this supply header to provide the natural gas for the GR system. The tie-in pipe supplied gas to a control and metering station and from this station natural gas was distributed to gas injection nozzles located above the cyclone barrel re-entrant throats. The natural gas valve train, common to all of the injection nozzles, included flow metering and control equipment, and safety shut-off valves. 
An FGR system was also included, hot flue gas was drawn from the economizer flue gas outlet with an FGR fan, routing the flue gas to the natural gas injectors. The purpose of using FGR with natural gas injection is to increase the dispersion and mixing of natural gas throughout the furnace Reburn zone. The use of FGR can increase the NOx reduction efficiency of natural gas reburning systems on large furnace boxes and on units with low reburn zone residence times. The FGR system included a multiclone for particulate removal upstream of the FGR fan.

OFA was assumed supplied from the existing hot secondary combustion air windbox. The existing windbox pressure on a cyclone-fired unit is adequate, so booster fans were not required. The installation of natural gas/flue gas injectors and OFA ports requires furnace tubewall modifications. The high windbox pressure of cyclone-fired units, 30 " to 75 " WC depending on whether the unit is a forced draft or balance draft unit, precludes the necessity of adding booster air blowers for the OFA system. The total cost of equipment and materials for the GR system was estimated at $\$ 1,130,069$. The following is a list of equipment/material and costs by area, that make up the total equipment and materials cost for the system.

Equipment/Materials Description

Natural Gas Injection Unit:

NG Supply Piping

NG Valve Train Piping

NG Header Piping

NG Injector Piping

NG Nozzle Flex Hose

NG Injection Assembly

NG Vent Piping

NG Instrumentation, Valves \& Dampers

NG Tubewall Modifications

NG Injector Cooling Air Piping
Equipment/Material Cost

$\$ 125,488$ 
FGR Fan

Hot FGR Duct to Inlet of Fan

FGR Duct from Fan to Boiler

FGR Injector Duct Header

OFA Unit:

OFA Main Ductwork

OFA Main Duct Expansion Joints

OFA Branch Ductwork

OFA Branch Duct Expansion Joints

OFA Nozzle Ducts

OFA Nozzle Supports

OFA Injection Nozzles

OFA Instrumentation \& Dampers

OFA Tubewall Modifications

Other:

$\$ 81,600$

Control Modifications

Electrical Work

New Structural Steel

The estimated total capital requirement to retrofit a GR system to an existing $300 \mathrm{MWe}$ cyclone-fired unit is $\$ 5,060,000$ or a cost of $\$ 16.85 / \mathrm{kWe}$. The breakdown of costs is presented in Table 7-1.

\subsubsection{GR - Projected Operating and Maintenance Costs}

EER conducted analyses to evaluate the fixed and variable (operating) costs of a GR system for a $300 \mathrm{MWe}$ coal cyclone-fired power plant (net heat rate of $10,000 \mathrm{Btu} / \mathrm{kWhr}$ before $\mathrm{GR}$ ); contributing cost factors were as follows: 


\section{Capital Cost}

Category

$\begin{array}{ccc}\$ 10^{6} & \$ / \mathrm{kWe} \\ 1.13 & 3.77 \\ 0.92 & 3.07 \\ 0.78 & 2.60 \\ 0.15 & 0.49 \\ 0.00 & 0.00 \\ 0.45 & 1.50\end{array}$

Gas Metering \& Reduction Station

\begin{tabular}{ccc}
0.45 & & 1.50 \\
3.43 & & 11.43 \\
0.34 & & 1.14 \\
0.45 & & 1.49 \\
0.63 & & 2.11 \\
4.85 & & 16.17 \\
0.00 & & 0.00 \\
\hline 4.85 & & 16.17 \\
0.02 & 0.06 \\
0.15 & 0.49 \\
0.04 & 0.15 \\
0.00 & 0.00 \\
\hline \hline 5.06 & 16.85 \\
\hline \hline
\end{tabular}

Total Capital Requirement

[1] Gas supply availability at site assumed adequate

[2] No allowance included based on DOE guideline

[3] Assumed downtime to be during scheduled major outage 
1. Reburning Fuel Cost Differential Since gas costs more than coal on a heating value basis $\left(\$ / 10^{6} \mathrm{Btu}\right)$, there is a cost related to the amount of gas fired. This was calculated based on the delivered costs of gas and coal and the percentage of gas fired $\left(20.1 \%\right.$ of the total heat input). A value of $\$ 1.00 / 10^{6}$ Btu was used as the differential between the delivered price of natural gas $\left(\$ 2.47 / 10^{6} \mathrm{Btu}\right)$ and the delivered price of coal $\left(\$ 1.47 / 10^{6} \mathrm{Btu}\right)$.

2. Changes in Boiler Efficiency Since the boiler efficiency is lower when using gas as the reburning fuel there needs to be an increase in the amount of fuel fired to make up for the lower efficiency. This increase was based upon a boiler efficiency loss $(1.27 \%)$ with GR and a composite fuel cost of $\$ 1.67 / 10^{6} \mathrm{Btu}$.

3. Reduced Load on Coal Crushers Since the GR fuel contributes a significant portion of the boiler fuel, there is a corresponding percentage decreased load on the coal crushers. The electricity credit was based on an auxiliary power cost of $\$ 0.02 / \mathrm{kWhr}$.

4. Maintenance Items/Spare Parts An allowance of $2 \%$ of the total plant investment was used for total maintenance, $40 \%$ of this $2 \%$ was allocated for maintenance items and spare parts.

5. Maintenance Labor An allowance of $2 \%$ of the total plant investment was used for total maintenance, $60 \%$ of this $2 \%$ was allocated for maintenance labor.

6. Administration and General Overhead An allowance of $60 \%$ of plant labor was added to cover administration and general overhead.

7. Local Property Taxes and Insurance An allowance of $3 \%$ of total plant investment was used to cover taxes and insurance.

8. $\mathrm{NO}_{x}$ Reduction $\mathrm{ANO}_{\mathrm{x}}$ reduction of $67 \%$ was assumed at $20.1 \%$ of the total heat input as reburn fuel. This is based on a $300 \mathrm{MWe}$ unit having a higher initial $\mathrm{NO}_{x}$ concentration and longer reburn residence zone time, and therefore a higher $\mathrm{NO}_{x}$ reduction with less gas than the CWLP unit.

The total annual incremental gross operating cost for the GR system, exclusive of any payback of capital, is estimated at $\$ 4,177,496$. If an $\mathrm{SO}_{2}$ allowance credit is taken based on the reduction of fuel sulfur when firing natural gas, the net operating cost is estimated at $\$ 3,422,703$. This $\mathrm{SO}_{2}$ credit was based on an allowance of $\$ 95 /$ ton (Feb. 1996). The operating cost breakdown for the GR system retrofit to a $300 \mathrm{MWe}$ cyclone-fired unit is shown in Table 7-2. 


\section{TABLE 7-2. 300 MWe CYCLONE-FIRED UNIT. GR OPERATING COST}

\section{Annual Incremental Operating Costs ${ }^{[1]}$}

Annual Use

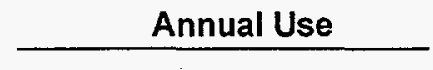

Variable Costs

Fuel:

Natural Gas

Supplemental Fuel

Utilities:

Electricity

Ash Disposal Credit

Sub-Total
Cost/Unit

Cost $\mathrm{Yr}$

$$
\begin{array}{lr}
\$ 1.00 / 10^{6} \mathrm{Btu}^{[2]} & \$ 3,436,898 \\
\$ 1.67 / 10^{6} \mathrm{Btu}^{[3]} & \$ 407,131
\end{array}
$$

$\$ 75,888$

$\$ 20.00 / 10^{3} \mathrm{kWhr}$

$\$ 9.29$ ton $^{[4]}$

$(\$ 31,484)$

Fixed Costs

Labor: [5]

Maintenance ( $2 \%$ of TPI $\times 60 \%$ )

$\$ 58,201$

Supervision ( $20 \%$ of Maintenance Labor)

$\$ 11,640$

Supplies:

Maintenance ( $2 \%$ of TPI $\times 40 \%$ )

$\$ 38,801$

Admin. and Gen. Ovhd. (60\% of total labor)

$\$ 34,920$

Local Taxes and Insurance @ 3\% of TPI

$\$ 145,502$

Sub-Total

Total Gross Operating Cost

SO2 Allowance @ \$95/ton ${ }^{[6]}$

Total Net Operating Cost

[1] 65\% Capacity factor @ 300 MWe net capacity $(10,000$ Btu/kWhr heat rate) w/ 20.1\% fuel heat input as natural gas

[2] Natural gas assumed delivered at $\$ 2.47 / \mathrm{MM}$ Btu; coal cost at $\$ 1.47 / \mathrm{MM}$ Btu

[3] Extra fuel added to make up for loss in efficiency (1.27\%) at same coal/gas ratio as reburn

[4] Credit for less fly ash, based on $25 \%$ carryover, assuming cyclone bottom slag can be disposed of at no cost

[5] Assumed no added operating labor required to operate the GR system

[6] February 1996 Allowance Credit Value, reduction based on $4.8 \mathrm{lb}$ SO2/MM Btu for coal w/coal reduction of $19.84 \%$ 


\subsubsection{GR - Summary of Performance and Economics}

Based on the developed capital and fixed/variable operating costs, economic projections were made using current dollars which include an inflation rate of $4.0 \%$, and constant dollars which ignore inflation. The factors used in the development of the technology economics are shown in Table 7-3. Table 7-4 shows the performance and cost for a 300 MWe GR System that is retro-fitted to a cyclone-fired boiler. The table reflects the NOx reduction costs based on a $65 \%$ capacity factor with $20.1 \%$ of the heat input supplied by natural gas at a gas to coal price differential of $\$ 1.00 /$ million Btu. The incremental increase in the levelized cost of power, including capital charges is estimated at $2.81 \mathrm{mills} / \mathrm{kWhr}$ in constant dollars and $3.69 \mathrm{mills} / \mathrm{kWhr}$ in current dollars.

If an $\mathrm{SO}_{2}$ credit is applied based on fuel sulfur reduction when firing natural gas, the net incremental increase in the levelized cost of power is estimated at $2.37 \mathrm{mills} / \mathrm{kWhr}$ in constant dollars and $3.11 \mathrm{mills} / \mathrm{kWhr}$ in current dollars. The levelized cost of $\mathrm{NO}_{\mathrm{x}}$ removal is estimated at $\$ 646 /$ ton and $\$ 847 /$ ton for current and constant dollar projections, respectively. If an $\mathrm{SO}_{2}$ credit is applied based on fuel sulfur reduction, the net levelized cost of $\mathrm{NO}_{\mathrm{x}}$ removal is estimated at $\$ 544 /$ ton and $\$ 713 /$ ton for current and constant dollar projections, respectively.

Based on the levelized cost (in constant dollars) for reducing nitrogen oxides, excluding $\mathrm{SO}_{2}$ credits, the capital charge component made up around $13 \%$ of the total cost of $\mathrm{NO}_{\mathrm{x}}$ reduction. The fixed operation and maintenance costs represented only $6 \%$, and the variable cost made up the rest of the cost for removing $\mathrm{NO}_{\mathrm{x}}$. The cost of $\mathrm{NO}_{x}$ removal shows that the variable operating cost is the greatest cost component, making up some $81 \%$ of the NOx reduction. Further, the most significant component of the variable operating cost is the cost of natural gas. 


\begin{tabular}{|c|c|c|}
\hline Item & Units & Value \\
\hline Cost of debt & $\%$ & 8.5 \\
\hline Inflation rate & $\%$ & 4.0 \\
\hline Construction period & mos. & 9 \\
\hline Remaining life of power plant & - & 15 \\
\hline Year for cost presented in this report & - & 1996 \\
\hline Royalty allowance based on total process capital & $\%$ & 0.5 \\
\hline Capital charge factor - current dollars & - & 0.160 \\
\hline Capital charge factor - constant dollars & - & 0.124 \\
\hline O\&M cost levelization factor - current dollars & - & 1.314 \\
\hline O\&M cost levelization factor - constant dollars & - & 1.000 \\
\hline Power plant size & MWe (net) & 300 \\
\hline Power plant type & cyclone & - \\
\hline Power plant capacity factor & $\%$ & 65 \\
\hline Sales tax rate & $\%$ & 5.0 \\
\hline Cost of freight & $\%$ & 2.0 \\
\hline Engineering/home office fees of total process capital & $\%$ & 18.0 \\
\hline
\end{tabular}




\section{TABLE 7-4. GR RETROFIT COST AND PERFORMANCE SUMMARY}

\section{Summary of Data}

Power Plant Attributes

Plant capacity, net

Power produced, net

Capacity factor

Plant life

Coal feed

Sulfur in Coal

Units
MWe
$10^{9} \mathrm{kWhr} / \mathrm{yr}$
$\%$
$\mathrm{yr}$
tons/yr
$\mathrm{wt} \%$

Value

300

1.71

65

15

683,280

3.0

Emissions Control Data

Removal efficiency

Emissions standard

Emissions without controls

Emissions with controls

Amount reduced

$\begin{array}{cc}\text { Units } & \text { NOx } \\ \% & 67.0 \\ \mathrm{lb} / 10^{6} \mathrm{Btu} & 0.86 \\ \mathrm{lb} / 10^{6} \mathrm{Btu} & 1.30 \\ \mathrm{lb} / 10^{6} \mathrm{Btu} & 0.43 \\ \text { tons } / \mathrm{yr} & 7,439\end{array}$

Levelized Cost of Power

Current Dollars

Capital Charge

Factor

Mills/kWhr

0.160

0.47

1.314

0.22

2.99

Variable Operating Cost

1.314

3.69

1.314

(0.58)

3.11

Constant Dollars

Factor

0.124

Mills/kWhr

$\mathrm{SO}_{2}$ Credits

Total Cost $w / \mathrm{SO}_{2}$ Credits
0.37

0.17

2.28

2.81

2.37

\section{Levelized Cost - NOx Removal Basis}

\$iton

Factor

0.160

Variable Operating Cost

Total Cost

$\mathrm{SO}_{2}$ Credits

Total Cost w/SO 2 Credits
1.314

1.314

\section{removed}

Factor

0.124

1.000

1.000

687

847

1.314

(133)

713

Basis: $67 \%$ NOx reduction assumed based on larger unit with longer Reburn zone residence time than CWLP 33 MWe cyclone unit ( $58 \%$ NOx reduction w/20\% gas heat input as Reburn fuel). 
The cost of $\mathrm{NO}_{x}$ reduction was analyzed and certain variables were then selected to perform sensitivity analyses. The variables chosen were natural gas price, the capacity factor and the unit size, the effects of these variables are shown Table 7-5.

TABLE 7-5. COST OF NO REMOVAL $^{2}$

\begin{tabular}{|c|c|c|c|c|c|c|}
\hline Natural Gas Price, $\$ 10^{6} \mathrm{Btu}^{*}$ & $\$ 0.50$ & $\$ 1.00$ & $\$ 1.50$ & & & \\
\hline NOx Reduction Cost, \$/ton** & $\$ 310$ & $\$ 544$ & $\$ 779$ & & & \\
\hline Capacity Factor & $50 \%$ & $55 \%$ & $60 \%$ & $65 \%$ & $70 \%$ & $75 \%$ \\
\hline NOx Reduction Cost, \$/ton ${ }^{\star \star}$ & $\$ 584$ & $\$ 569$ & $\$ 555$ & $\$ 544$ & $\$ 535$ & $\$ 527$ \\
\hline Unit Size, MWe & 100 & 300 & 450 & 600 & 750 & 900 \\
\hline NOx Reduction Cost, \$/ton** & $\$ 652$ & $\$ 544$ & $\$ 521$ & $\$ 507$ & $\$ 497$ & $\$ 490$ \\
\hline
\end{tabular}

Note: Base case variables in bold

* Differential price compared to coal

** Constant dollar basis, includes $\$ 95 /$ ton $\mathrm{SO}_{2}$ credit

For the sensitivity analysis, only the variable being analyzed was changed from the base case, all other variables were kept the same. The cost of natural gas is clearly the driving force for the economics of the GR System. A $\$ 0.50$ swing in the price of natural gas has the effect of changing the cost of $\mathrm{NO}_{x}$ reduction by over $\$ 200 /$ ton. The effect of capacity factor has a relatively small effect on the cost of $\mathrm{NO}_{x}$ removal. A $10 \%$ swing in capacity factor results in a $\$ 17$ to $\$ 25 /$ ton variation in the cost for reducing $\mathrm{NO}_{x}$ emissions.

To examine the power plant size effect on NOx reduction costs, the capital cost of the 300 MWe unit was used as a base. A scale up factor of 0.75 was used to extrapolate the capital cost for smaller and larger units. This factor was based on a combination of $50 \%$ of the equipment being increased in size using a 0.6 scaleup factor and $50 \%$ of the equipment being duplicated using a 0.9 scale up factor. The size effect for units larger than $300 \mathrm{MWe}$ has only a slight effect on the cost of $\mathrm{NO}_{\mathrm{x}}$ reduction. For a $900 \mathrm{MWe}$ unit 
the cost of $\mathrm{NO}_{x}$ reduction is only $\$ 54 /$ ton less than that for the $300 \mathrm{MWe}$ unit. With smaller units the effect is more dramatic, for a $100 \mathrm{MWe}$ unit the cost of NOx reduction would be $\$ 108 /$ ton more than that for the $300 \mathrm{MWe}$ unit.

\subsubsection{GR - Comparison with other $\mathrm{NO}_{x}$ Control Technologies}

Methods for controlling $\mathrm{NO}_{x}$ from coal-fired utility boilers include combustion modifications and post combustion treatment of the flue gas. Combustion modifications involve operating the primary combustion zone under fuel rich conditions (and therefore reduced temperatures), cooling the flame at a higher rate, and dilution of the flame to reduce adiabatic flame temperatures. Gas residence times in the high temperature zone as well as excess air levels are reduced, inhibiting the formation of fuel and thermal $\mathrm{NO}_{\mathrm{x}}$.

The combustion modification techniques that can be applied depends on the type of boiler and method of firing the fuel. Low $\mathrm{NO}_{\mathrm{x}}$ burner technology with OFA has been successfully applied to wall and tangentially fired pulverized coal units. Low $\mathrm{NO}_{x}$ burner technology, however, cannot be applied to cyclone units due to the configuration of the cyclone furnaces. The importance of OFA as it relates to staging the combustion process has been determined in testing of low $\mathrm{NO}_{x}$ burner retrofits and demonstrations. This information has promoted the addition of OFA to conventional firing systems as a stand alone alternative to low $\mathrm{NO}_{\mathrm{x}}$ burners for utilities requiring moderate reductions.

OFA systems may be "close-coupled" to the existing burner assemblies on tangentially fired units, or separated higher into the furnace on both tangentially and wall fired designs for deeper staging and increased $\mathrm{NO}_{x}$ reductions. Staged combustion with OFA also cannot be applied to cyclone-fired units with high sulfur coal feedstocks. Industry experience indicates that this combustion modification technique for high sulfur feedstocks results in high levels of corrosion in the cyclone barrels. 
Post combustion techniques include reburning, selective catalytic reduction (SCR), and selective non-catalytic reduction (SNCR). The reburning process using natural gas as the reburning fuel is described elsewhere in this manual. Coal and coal water slurry (CWS) have also been proposed as reburning fuels. In Table 7-6 below, a relative comparison is made between the cost, design, and operating factors associated with the three reburning fuels.

Table 7-6. Reburning Fuel Comparison

\begin{tabular}{||c|c|c|c||}
\hline & Natural Gas & Coal & CWS \\
\hline Reburning Fuel Cost & Highest & None & Low \\
\hline Capital Cost & Lowest & Highest & Low \\
\hline $\mathrm{SO}_{2}$ Reduction & Yes & None & Varies \\
\hline Injector Size & Small & Large & Small \\
\hline Auxiliary Power & Low & High & Moderate \\
\hline Residence Time Requirement & Low & Moderate & Moderate \\
\hline
\end{tabular}

Natural gas is the most expensive reburning fuel, with the differential above coal averaging $\$ 1.00$ to $\$ 1.50 / 10^{6} \mathrm{Btu}$. Coal reburning involves no differential fuel cost since the total heat input to the unit does not change. The cost of CWS is site specific depending on the cost and the availability of the coal fines used to formulate the slurry. CWS may be produced by wet milling the primary coal ( $\$ 4 /$ ton), using the minus 100 mesh froth cell product from coal cleaning plants, or recovering coal fines from coal preparation plant ponds with advanced coal cleaning techniques (delivered cost could be less than primary coal cost or higher depending on ownership of resource, quality of impounded coal and distance from power plant). Other fuels, like fuel oil and Orimulsion ${ }^{\circledR}$, a Venezuelan bitumen-water emulsion can also be used as effective reburning fuels.

If gas is available at the power plant, GR offers the lowest capital cost investment since there are no fuel preparation or handling equipment requirements. Coal reburning will require the addition of coal handling and milling equipment, milling equipment upgrading, 
or storage and handling equipment for coal fines produced elsewhere. Reburning with slurry requires CWS feeding equipment, added air compression for CWS atomization, and either onsite CWS storage or CWS formulation equipment for delivered coal fines filter cake.

Since natural gas contains no sulfur, GR offers an additional $\mathrm{SO}_{2}$ reduction over that provided by SI or other processes since gas replaces coal containing sulfur. For normal GR applications gas would replace coal and $\mathrm{SO}_{2}$ would be reduced some $20 \%$.

Auxiliary power requirements for $G R$ are relatively lower since fuel handling and preparation equipment is not necessary as it is with reburning using coal or CWS as the reburn fuels. Demonstrations of GR with FGR have shown that, with most furnace designs and adequate natural gas pressures available, the FGR may not be necessary to promote adequate mixing of the natural gas with the furnace gases. In such a case, the FGR fan can be eliminated, further reducing the auxiliary power requirements.

Consideration of the furnace geometry and available residence time may be critical in the selection of the reburning fuel. Natural gas requires the shortest residence time for the reburning process since the fuel "particle" size is at the molecular level. Coal, having larger particle sizes will require longer residence times.

Selective catalytic and non-catalytic reduction are post combustion treatment methods. In the selective catalytic reduction process, ammonia vapor and preheated air are mixed and injected into the flue gas at the boiler exit. The optimum temperature window for this process is 550 to $750^{\circ} \mathrm{F}$. Flue gas at this temperature is generally available upstream of the unit's air heater. A catalytic converter is installed in the duct work at this location. $\mathrm{NO}_{\mathrm{x}}$ is reduced by the process to diatomic nitrogen in the converter. SCR systems are better suited for installation downstream of a hot side precipitator since dust buildup and catalyst fouling are reduced. On systems installed upstream of a cold side precipitator, the catalyst 
mesh size must be increased to reduce dust build-up and catalyst fouling. The larger mesh size dictates a larger converter to provide the necessary surface area.

Ammonia slip (un-reacted $\mathrm{NH}_{3}$ ) is a major operating consideration with SCR systems. As the catalyst is expended, ammonia slip increases. Ammonia passing through the converter forms ammonium sulfate in particulate form which may foul equipment downstream such as air heaters, draft fans, or precipitators. Sulfates may also form in the catalyst pores to deactivate the catalyst if the flue gas temperature drops below $500^{\circ} \mathrm{F}$. Un-reacted ammonia may also be adsorbed by the fly ash and increase the leachability of metals in the ash, affecting the salability of the fly ash.

In the SNCR process, ammonia or urea based reagents are injected into the upper furnace at locations where flue gas temperatures range from 1600 to $2000^{\circ} \mathrm{F}$. With this process the required high activation energy is provided by the temperature of the flue gas, and a converter with catalyst is not necessary.

An independent study completed for the U.S. EPA (Contract No. 68-D2-0168) "Investigation of Performance and Cost of $\mathrm{NO}_{x}$ Controls as Applied to Group 2 Boilers", compared the costs of competing $\mathrm{NO}_{\mathrm{x}}$ control technologies. The costs for various $\mathrm{NO}_{\mathrm{x}}$ reduction systems applied to cyclone-fired units were developed as part of this study. The values for GR system are slightly different than those developed by EER due to different cost assumptions. Although actual costs vary, the relative costs for the technologies evaluated should be valid. In Table 7-7, the cost of Gas Reburning, Coal Reburning, Selective Non-Catalytic Reduction (SNCR) and Selective Catalytic Reduction (SCR), based on $\$ / \mathrm{kWe}$ and $\$ /$ ton of $\mathrm{NO}_{\mathrm{x}}$ removed are shown for $400 \mathrm{MWe}$ cyclone-fired units. As shown in the table, the cyclone-fired boiler $\mathrm{NO}_{\mathrm{x}}$ control technologies show a cost per ton of $\mathrm{NO}_{x}$ removed that ranges from approximately $\$ 490$ to $\$ 690$. Based on this comparison Coal Reburning is the least expensive and SNCR the most expensive with GR and SCR being near equal when the price differential between natural gas and the primary coal is $\$ 1.00 / 10^{6} \mathrm{Btu}$. The $\mathrm{NO}_{\mathrm{x}}$ reduction for SCR assumed for this study was low, only $50 \%$. 
TABLE 7-7. 400 MWe CYCLONE-FIRED NO ${ }_{x}$ CONTROL COMPARISON

\begin{tabular}{||l|c|c|c||}
\hline \multicolumn{1}{|c|}{ Technology } & $\begin{array}{c}\text { NOx Reduced } \\
\%\end{array}$ & $\begin{array}{c}\text { Capital Cost } \\
\$ / \mathrm{kWe}^{\mathrm{W}}\end{array}$ & $\begin{array}{c}\mathrm{NO}_{\mathrm{x}} \text { Removed }^{4} \\
\$ / \text { ton }\end{array}$ \\
\hline Gas Reburning & 1 & 15.2 & 590 \\
\hline Coal Reburning & 60 & 52.7 & 490 \\
\hline $\mathrm{SNCR}^{2}$ & 50 & 7.3 & 690 \\
\hline $\mathrm{SCR}^{3}$ & 35 & 40.0 & 575 \\
\hline
\end{tabular}

(1) Natural Gas @ $\$ 2.47 / 10^{6}$ Btu and Coal @ $\$ 1.47 / 10^{6}$ Btu

(2) $50 \%$ Urea solution @ \$0.50/gal

(3) Anhydrous Ammonia @ \$162/ton \& SCR catalyst replacement (3 yr life) @ \$350/ft

(4) Base levelized costs

However, SCR systems have achieved $85 \%+$ reductions with increased catalyst volume. For $\mathrm{NO}_{\mathrm{x}}$ reduction beyond what is possible by a particular technology, it is possible to combine some technologies for deeper reduction. For an example, Advanced GR is currently being marketed involving the simultaneous application of GR and SNCR. Overall $\mathrm{NO}_{x}$ reduction is expected to be in the range of 75 to 90 percent. GR has also been demonstrated with low $\mathrm{NO}_{x}$ burners, achieving an overall $\mathrm{NO}_{x}$ reduction of 75 percent.

\subsection{SI System}

The SI system was designed to store, meter, and convey micronized hydrated lime (sorbent) to the injection nozzles in the upper furnace of the $300 \mathrm{MWe}$ cyclone-fired Unit. The SI system is comprised of the following major components: sorbent storage silo, weigh hopper, rotary valve feeder, screw pump, air transport blower, conveying line, sorbent splitter, SI air fan, and furnace injection nozzles.

\subsection{1 $\quad$ SI-Economic Parameters}

The economic parameters were the same as that used for GR (See Section 7.1.1 and Table 7-3 in Section 7.1.4). 
The total cost of equipment and materials for the SI system was estimated at $\$ 883,278$.

The following is a list of equipment/material and costs by area, that make up the total equipment and materials cost for the system.

Equipment/Materials Description

Sorbent Storage Unit:

Sorbent silo

Weigh hopper

Silo vent filter

Sorbent Feeding Unit:

Rotary valves

Sorbent screw pumps

Sorbent transport blowers

Dust control unit

Sorbent Transport:

Piping, hoses, valves, splitters

Sorbent equipment air compressors

Air dryer

Valves and controls

Sorbent Injection Unit:
Equipment/Material Cost

$\$ 134,710$

$\$ 232,774$

$\$ 361,686$

$\$ 154,108$

Coaxial jet sorbent injectors, C.S.IS.S.

Sl air fan

SI nozzle cooling fan

Instruments/controls

The estimated total capital requirement to retrofit an SI system to an existing $300 \mathrm{MWe}$ cyclone-fired unit is $\$ 3,860,000$ or a cost of $\$ 12.86 / \mathrm{kWe}$. A breakdown of the capital cost is presented in Table 7-8. 
TABLE 7-8. 300 MWe CYCLONE-FIRED UNIT SI RETROFIT CAPITAL COST

\section{Capital Cost}

Category

Equipment

Construction Labor

Construction Indirects

Other (6\%), Freight (2\%) \& Taxes $(5 \%)$

Total Process Capital

Engineering (10\% of process capital

Project Management (8\%) /Owners Costs (5\%)

Project Contingency @15\%

Total Plant Cost

Allowance for Funds During Construction ${ }^{[1]}$

Total Plant Investment (TPI)

Royalty Fees @ $0.5 \%$ of Total Process Capital

Startup Costs @ 3\% TPI

Working Capital @ 0.9\% TPI \& 14 days supply $\mathrm{Ca}(\mathrm{OH})_{2}$

Cost of Construction Downtime (21 days) ${ }^{[2]}$

Total Capital Requirement

[1] No allowance included based on DOE guideline

[2] Assumed downtime to be during scheduled major outage
$\$ 10^{6}$

0.88

0.72

0.61

0.11

2.33

0.23

0.30

0.43

3.29

0.00

3.29

0.01

0.10

0.46

$\frac{0.00}{3.86}$
1.52 0.00

$\$ / k W e$ 2.94

2.40

2.03

0.38

7.75

0.78

1.01

10.97

0.00

10.97

0.04

0.33

12.86 


\subsubsection{SI - Projected Operating Maintenance Cost}

EER evaluated the fixed and variable operating costs of an SI system for a $300 \mathrm{MWe}$ coal cyclone-fired power plant; contributing cost factors were as follows:

1. Cost of Hydrated Lime Sorbent The purchased price for hydrated lime was based on the costs incurred for the CCT demonstrations, \$83/ton.

2. Sootblowing The frequency of sootblowing was increased for a power plant with an SI system.

3. Ash Disposal An increase of ash disposal results from the addition of sorbent to the boiler furnace.

4. Auxiliary Power The power increases due to the added air blower and air compressor horsepower requirement

5. Maintenance Items/Spare Parts An allowance of $3 \%$ of the total plant investment was used for total maintenance, $40 \%$ of this $3 \%$ was allocated for maintenance items and spare parts.

6. Maintenance Labor An allowance of $3 \%$ of the total plant investment was used for total maintenance, $60 \%$ of this $3 \%$ was allocated for maintenance labor.

7. Administration and General Overhead An allowance of $60 \%$ of plant labor was added to cover administration and general overhead.

8. Local Property Taxes and Insurance An allowance of $3 \%$ of total plant investment was used to cover taxes and insurance.

The total annual incremental gross operating cost for the SI system, exclusive of any payback of capital, is estimated at $\$ 8,610,679$. The operating cost breakdown for the SI system retrofit for a 300 MWe cyclone-fired unit is presented in Table 7-9.

\subsubsection{SI-Summary of Performance and Economics}

Based on the developed capital and operating costs, economic projections were made using current dollars, which include an inflation rate of $4.0 \%$, and constant dollars which 


\section{Annual Incremental Operating Costs ${ }^{[1]}$}

\begin{tabular}{|c|c|c|c|}
\hline & Annual Use & Cost/Unit & Cost/ Yr \\
\hline \multicolumn{4}{|l|}{ Variable Costs } \\
\hline \multicolumn{4}{|l|}{ Raw Material: } \\
\hline Hydrated Lime ${ }^{[2]}$ & 87,327 tons & $\$ 83.00 /$ ton & $\$ 7,248,101$ \\
\hline \multicolumn{4}{|l|}{ Utilities: } \\
\hline Electricity & $10,48010^{3} \mathrm{kWhr}$ & $\$ 20.00 / 10^{3} \mathrm{kWhr}$ & $\$ 209,597$ \\
\hline Ash Disposal & 97,759 tons & $\$ 9.29 /$ ton & $\$ 908,180$ \\
\hline Sub-Total & & & $\$ 8,365,878$ \\
\hline
\end{tabular}

Fixed Costs

Labor: ${ }^{[3]}$

Maintenance ( $3 \%$ of TPI $\times 60 \%$ )

$\$ 59,226$

Supervision ( $20 \%$ of Maintenance Labor)

Supplies:

Maintenance ( $3 \%$ of TPI $\times 40 \%$ )

Admin. and Gen. Ovhd. (60\% of total labor)

$\$ 35,536$

Local Taxes and Insurance @ 3\% of TPI

$\$ 98,710$

Sub-Total

$\$ 244,801$

Total Operating Cost

$\$ 8,610,679$

[1] 65\% Capacity factor @ 300 MVe net capacity $(10,000$ Btu/kWhr heat rate)

[2] $95 \% \mathrm{Ca}(\mathrm{OH}) 2$ with $\mathrm{Ca} / \mathrm{S}$ ratio of 1.75

[3] No incremental operating labor 
ignore inflation. Table 7-10 shows the performance and cost for an SI System that is retrofitted to a $300 \mathrm{MWe}$ cyclone-fired boiler. The incremental increase in the levelized cost of power is estimated at $5.32 \mathrm{mills} / \mathrm{kWhr}$ in constant dollars and $6.98 \mathrm{mills} / \mathrm{kWhr}$ in current dollars. The levelized cost of $\mathrm{SO}_{2}$ removal is estimated at $\$ 490 /$ ton and $\$ 643 /$ ton for constant and current dollar projections, respectively.

\subsubsection{SI-Effect of Variables on Economics}

The cost of $\mathrm{SO}_{2}$ reduction was analyzed and certain variables were then selected to perform sensitivity analyses. Based on the levelized cost (constant dollars) for reducing sulfur dioxide emissions, the capital charge component made up only $5.3 \%$ of the total cost. The fixed operation and maintenance costs represented only $2.6 \%$, and the variable cost $(92.1 \%)$ made up the rest of the cost for removing $\mathrm{SO}_{2}$. The hydrated lime accounted for some $87 \%$ of the variable costs.

The variables chosen were the cost of hydrated lime, the capacity factor, the unit size and

the percentage of sorbent utilization. For the sensitivity analysis, only the variable being analyzed was changed with all other variables being kept the same. The hydrated lime and how well it is utilized is the driving force for the economics of the SI System. The effect of the variables analyzed, on the cost of $\mathrm{SO}_{2}$ removal, is shown in Table 7-11.

A $\$ 20 /$ ton swing in the price of hydrated lime has the effect of changing the cost of $\mathrm{SO}_{2}$ removal by some $\$ 95 /$ ton. The effect of capacity factor has a relatively small effect on the cost of $\mathrm{SO}_{2}$ removal. A $10 \%$ swing in capacity factor results in a $\$ 5-\$ 7 /$ ton variation in the cost of $\mathrm{SO}_{2}$ removal. The capital cost of the $300 \mathrm{MWe}$ unit was used as a base and a scale up factor of 0.7 was used to extrapolate the capital cost for larger units. This factor was based on a combination of some $70 \%$ of the equipment being increased in size using a 0.6 scaleup factor and some $30 \%$ of the equipment being duplicated using a 0.9 scale up factor. 


\section{TABLE 7-10. SI RETROFIT COST AND PERFORMANCE SUMMARY}

\section{Summary of Data}

Power Plant Attributes

Plant capacity, net

Power produced, net

Capacity factor

Plant life

Coal feed

Sulfur in coal

Units
MWe
$10^{9} \mathrm{kWhr} / \mathrm{yr}$
$\%$
$\mathrm{yr}$
tons/yr
wt $\%$

Value

Removal efficiency

Emissions standard

Emissions without controls

Emissions with SI control

Amount reduced

\section{Emissions Control Data}

$\begin{array}{cc}\text { Units } & \mathrm{SO}_{2} \\ \% & 45 \\ \mathrm{lb} / 10^{6} \mathrm{Btu} & 1.20 \\ \mathrm{Ib} / 10^{6} \mathrm{Btu} & 4.80 \\ \mathrm{lb} / 10^{6} \mathrm{Btu} & 2.64 \\ \text { tons/yr } & 18,654\end{array}$

Levelized Cost of Power

Current Dollars Constant Dollars

Capital Charge

Factor

Milis/kWhr Factor

Mils/kWhr

Fixed O\&M

0.160

0.36

0.124

0.28

1.314

0.19

1.000

0.14

Variable Operating Cost

1.314

6.44

1.000

4.90

Total Cost

6.98

5.32

Levelized Cost - $\mathrm{SO}_{2}$ Removal Basis

\$/ton

$\$$ ton

Factor

removed

Factor

removed

Capital Charge

0.160

33

0.124

26

Fixed O\&M

1.314

20

1.000

15

Variable Operating Cost

1.314

589

1.000

448

Total Cost

643

490

Basis: $300 \mathrm{MWe}$ unit size and $65 \%$ onstream capacity factor

$26 \%$ calcium utilization @ Ca/S ratio of 1.75 and $\$ 83$ ton price for $95 \% \mathrm{Ca}(\mathrm{OH}) 2$ hydrated lime 
TABLE 7-11. COST OF $\mathrm{SO}_{2}$ REMOVAL*

\begin{tabular}{|l|c|c|c|c|c|c||}
\hline Hydrated Lime, \$/ton & 63 & 73 & 83 & 93 & 103 & \\
\hline $\mathrm{SO}_{2}$ Removal Cost, \$/ton & 395 & 442 & 490 & 537 & 584 & \\
\hline \hline Capacity Factor, \% & 50 & 55 & 60 & 65 & 70 & 75 \\
\hline $\mathrm{SO}_{2}$ Removal Cost, \$/ton & 501 & 497 & 493 & 490 & 487 & 485 \\
\hline \hline Unit Size, MWe & 100 & 300 & 500 & 700 & 900 & \\
\hline $\mathrm{SO}_{2}$ Removal Cost, \$/ton & 530 & 490 & 480 & 476 & 473 & \\
\hline \hline Sorbent Utilization,\% & 26 & 36 & 46 & & & \\
\hline SO $_{2}$ Removal Cost, \$/ton & 490 & 354 & 277 & & & \\
\hline
\end{tabular}

Note: Base case variables in bold

* Constant Dollar Basis

The unit size has a moderate effect on the cost of $\mathrm{SO}_{2}$ removal. For a $900 \mathrm{MWe}$ unit, the cost of $\mathrm{SO}_{2}$ removal is only some $\$ 17$ ton less than that for the $300 \mathrm{MWe}$ unit. For smaller units the effect is greater; for a $100 \mathrm{MWe}$ unit the cost of $\mathrm{SO}_{2}$ removal would be some $\$ 40 /$ ton greater than that for a $300 \mathrm{MWe}$ unit. This is an economy of scale effect with the reduction in cost starting to taper off at the $300 \mathrm{MWe}$ size.

The sorbent utilization dramatically impacts the cost of $\mathrm{SO}_{2}$ removal because it affects the consumption rate of sorbent. For this economic analysis a $\mathrm{Ca} / \mathrm{S}$ ratio of 1.75 was used with an overall calcium utilization of $26 \%$. An increase in sorbent utilization from $26 \%$ to $46 \%$ would result in a drop of $\mathrm{SO}_{2}$ removal cost from $\$ 490 /$ ton to $\$ 277 /$ ton.

\subsection{6 $\mathrm{SI}$-Comparison with other $\mathrm{SO}_{2}$ Control Technologies}

The primary methods of coal-fired utilities used in complying with the 1990 Clean Air Act Amendments (CAAA) include switching from high sulfur Eastern coal to low sulfur Western coal, purchase of $\mathrm{SO}_{2}$ allowance credits and stack gas scrubbing. 


\section{Fuel Switching}

Fuel switching from high sulfur to low sulfur coals has seen increased interest since the passage of the 1990 CAAA, especially with the promotion very low sulfur coals from the Powder River Basin (PRB) of Wyoming. PRB coals are ranked as sub-bituminous and generally have a sulfur content of one half percent, but also have higher ash and moisture contents and lower heating values. In considering coal switching to low sulfur coals, fuel costs (including transportation) and operational or performance impacts are of major concern.

PRB coal (as mined) has been very competitively priced as compared to eastern and Midwestern bituminous coals, with transportation costs weighing heavily in the feasibility determination. Transportation of PRB coals to the Midwestern and Eastern U.S. has been exclusively by rail. Utilities switching to PRB coal are required to contract with one or more rail operating companies for transportation, and therefore become subject to future rate hikes or labor strikes which would interrupt delivery.

Delivery of design coal to an existing facility may have been by truck or river barge, and the plant may not have rail access or rail unloading facilities. Addition of rail spurs, car unloading equipment, handling equipment, and coal storage piles must be considered in the feasibility of the fuel switch. Utilities may also consider purchasing unit trains and yard locomotives as apposed to long term contracting for these services.

The moisture and ash content and lower heating value of PRB coal can have a significant impact on plant performance, and modifications may be required to accommodate the fuel. Milling capacity should be reviewed in terms of drying the higher moisture coal and increasing the mass through the pulverizers in order to avoid a unit derate. Spare mills may be lost due to the milling requirements, and modifications may be required to provide additional mills or additional heat input to the mills for drying of the coal. Since the western fuel has a higher moisture content, heat loss from the unit via the flue gas will increase as 
will the required firing rate. Due to the increased ash content, impacts on furnace slagging and convective section fouling must be addressed in terms of gas temperature profile changes and sootblower coverage. Increased ash loading will also affect the particulate collection device (ESP or baghouse) as well and ash handling systems and disposal.

\section{$\mathrm{SO}_{2}$ Allowance Credits}

Allowance credits may be purchased by the utility, emissions being set by the U.S. EPA and determined as $\mathrm{SO}_{2}$ emissions emitted in a base year between 1985 and 1987. The current NSPS also requires that 70 to 90 percent plus $\mathrm{SO}_{2}$ must be removed based on the sulfur content of the coal. Surplus allowance credits may result from fuel switching (low sulfur coal, oil, or gas), or over-scrubbing by any of the flue gas desulfurization technologies. The cost of credits is set by the supply and demand for such credits, being heavily influenced by the cost of delivery of PRB coal and control technology costs.

\section{Flue Gas Desulfurization (FGD)}

Many FGD processes have been developed, differing in the chemical reagents used in the process and the resulting end products or waste. Most processes return an unusable or "throw-away" product, while a small portion provide marketable sulfur or sulfate based products. Recovery processes require sophisticated chemical processing plants and the capital investment may be unattractive. These processes return reagent quality products and are not to be confused with FGD systems producing sludges that are disposed of sold, for example, as concrete admixtures. Discussion of all of the available processes is well beyond the scope of this manual, but the processes can be classified into three distinct categories; wet scrubbing, spray drying, or dry injection.

The wet scrubbing process involves exposure of the flue gas to sprays of an alkaline slurry mixture of water with crushed limestone or slaked lime. Other alkaline reagents such as sodium carbonate have also been used. The spraying of the alkaline slurry and absorption 
of the sulfur-dioxides in the flue gas occurs in a variety of absorber designs including venturi scrubbers, static packing scrubbers, moving bed scrubbers, tray tower absorbers, and spray tower absorbers. In the wet scrubbing process, only a portion of the water in the spray is evaporated as the flue gas is cooled to the adiabatic saturation temperature. The evaporation that occurs in the scrubbing process results in water vapor being discharged to the atmosphere, requiring make up water to be continually added to the process. Reheaters are often provided at the scrubber outlet to prevent condensation and corrosion problems in the downstream duct work, draft fans, and stack. End products are retained in the liquid scrubber effluent, and continuously removed by clarification and vacuum filtration producing the discharge known as "filter cake". Wet systems are located downstream of a particulate collection device to minimize fly ash contamination of the process and resulting end product.

In spray drying systems, flue gas is contacted with very finely atomized alkaline or slurry solutions. Evaporation of the water and absorption of the sulfur dioxide in the flue gas occurs almost simultaneously. The resulting end products are completely dry and can be collected by conventional particulate control devices such as precipitators and baghouses, and transported by conventional fly ash handling equipment. Spray drying and residence time in the flue gas prior to collection provides the initial contact between the atomized reactive slurry and the acid gas contaminants. The particulate control device is an integral part of the spray drying process providing additional contact time between the reactant and the flue gas. Spray drying processes are therefore better suited for application with baghouses rather than ESP's since the flue gas must pass through the cake of reactants on the bags. Dry scrubbing offers the advantages of minimal water consumption and elimination of reheat requirements since the flue gas is not reduced to the adiabatic saturation temperature as with wet scrubbing. However, dry scrubbing is usually economically limited to coals with low to medium sulfur contents since more expensive reagents such as lime or sodium carbonate are required. 
As described in this manual, $\mathrm{SI}$ involves pneumatic injection of dry sorbents such as hydrated lime or limestone into the furnace flue gases at temperatures of 2000 to $2250^{\circ} \mathrm{F}$. There are no on-site processing equipment requirements for the raw sorbent material since local suppliers can make adjustments in their production for the grind requirements of limestone and in the hydrating process for lime. SI also does not require slaking or slurry preparation equipment, or expensive absorber or spray towers.

The process equipment for SI includes silo storage, feed, transport, and injection equipment, and the capital cost is a fraction of wet or dry scrubbing systems. SI, however, does not offer the reduction capabilities of these competing technologies. $\mathrm{SO}_{2}$ capture with SI ranges from approximately 30 to 50 percent depending on the sulbur dioxide level in the flue gas (proportional to the sulfur in the coal), the type and feedrate of sorbent to be used, and the available residence time at desired temperatures in the boiler furnace. Higher removal efficiencies and sorbent utilization is realized with more reactive and expensive sorbents such as hydrated lime, which accounts for a significant portion of the operating costs.

$\mathrm{SI}$ also requires balance of plant modifications due to increased fouling of radiant and convective sections of the boiler, as well as impacts on particulate control devices, ash handling equipment, and ash disposal procedures. A possible benefit of DSI is the significant increase of the calcium content of the fly ash, improving the salability of the ash as a concrete admixture. If the product cannot be sold, disposal requirements may increase the Sl operating costs.

With the relatively lower capital costs and higher operating costs as compared to the wet or dry scrubbing systems, SI might be suited for application to aging plants with low capacity factors or relatively short operating lives. In order to reach full compliance while using SI, utilities may consider allowance purchasing, or over-scrubbing on newer units in their system. The $\mathrm{SO}_{2}$ removal cost of $\mathrm{SI}$ is compared to wet scrubbers, coal switching and the purchase of $\mathrm{SO}_{2}$ allowance credits in Table 7-12. 
TABLE 7-12. SI COMPARISON WITH OTHER $\mathrm{SO}_{2}$ CONTROL OPTIONS

\begin{tabular}{||l|c|c||}
\hline \multicolumn{1}{|c|}{ Technology } & $\mathrm{SO}_{2}$ Removal & $\begin{array}{c}\mathrm{SO}_{2} \text { Removed } \\
\$ / \text { ton }\end{array}$ \\
\hline $\mathrm{SI}$ & $30-50$ & $490^{1}$ \\
\hline $\mathrm{SO}_{2}$ Scrubbers & $90-95$ & $322^{2}$ \\
\hline Switch to Low Sulfur Coal & $65-85$ & $113^{3}$ \\
\hline $\mathrm{SO}_{2}$ Allowance Credits & $0-100$ & $110^{4}$ \\
\hline
\end{tabular}

(1) Nominal cost for $300 \mathrm{MWe}$ unit based on $26 \%$ calcium utilization and hydrated lime at $\$ 83 /$ ton

(2) Power Generation publication, 4/4/97, based on average cost for 80 scrubbers (1996 survey)

(3) Power Generation publication, 4/4/97, average of 112 units that switched to low sulfur Western coal

(4) Power Generation publication, 4/4/97, average selling price in 1996

With current economics, the SI technology will probably not be cost competitive with other available utility options for base and intermediate load units unless the SI calcium utilization can be increased and the cost of the lime based reagent decreased. 


\section{REFERENCES}

1. $\quad$ Reed, R. D., "Process for Disposal of Nitrogen Oxide." John Zink Company, U.S. Patent 1274637, 1969.

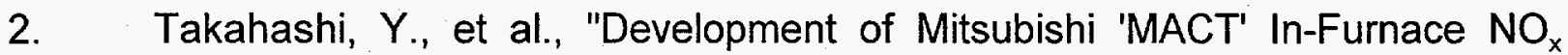
Removal Process." Presented at the U.S.-Japan $\mathrm{NO}_{x}$ Information Exchange, Tokyo, Japan, May 25-30, 1981. Published in Mitsubishi Heavy Industries, Ltd. Technical Review, Vol. 18, No. 2.

3. Chen, S. L., M. P. Heap, and D. W. Pershing, The Nineteenth Symposium (International) on Combustion, the Combustion Institute, 1983.

4. Greene, S. B., S. L. Chen, D. W. Pershing, M. P. Heap, and W. R. Seeker, "Bench Scale Process Evaluation of Reburning for In-Furnace $\mathrm{NO}_{\times}$Reduction," ASME Transactions Journal of Engineering for Gas Turbines and Power, 1985.

5. McCarthy, J. M., B. J. Overmore, S. L. Chen, W. R. Seeker, and D. W. Pershing, "Pilot Scale Process Evaluation of Reburning for In-Furnace $\mathrm{NO}_{x}$ Reduction," Final Report, EPA Contracts 68-02-3925 and 68-02-3955 Work Assignment No. 10, 1985.

6. U.S. Department of Energy. Office of Fossil Energy. "Enhancing the Use of Coals by Gas Reburning and Sorbent Injection; A Project Proposed by Energy and Environmental Research Corporation." Washington, D.C.: Government Printing Office, May 1987. DOE/FE-0087 CCT/87 PC 79796.

7. Energy and Environmental Research Corporation, "Enhancing the Use of Coals by Gas Reburning and Sorbent Injection," Comprehensive Report to Congress, Clean Coal Technology Demonstration Program, A Project Proposed by Energy and Environmental Research Corporation to the U.S. Department of Energy, Office of Fossil Energy, May, 1987.

8. Bartok, W. and Folsom, B. A., "Control of $\mathrm{NO}_{x}$ and $\mathrm{SO}_{2}$ Emissions by Gas Reburning-Sorbent Injection," presented at the American Institute of Chemical Engineers Annual Meeting, New York, New York, November 1987.

9. Payne, R., et. al., "Demonstration of Gas Reburning-Sorbent Injection $\mathrm{NO}_{x} / \mathrm{SO}_{2}$ Control Technology on Three Utility Boilers," presented at the American Institute of Chemical Engineers 1988 Summer National Meeting, Denver, Colorado, August 21-24, 1988. 
10. England, G. C., et. -al., "Prototype Evaluation of Sorbent Injection on a Tangentially Fired Utility Boiler," presented at the 1990 Joint EPA/EPRI $\mathrm{SO}_{2}$ Control Symposium, New Orleans, Louisiana, May 8-11, 1990.

11. Folsom, B. A. and Bartok, W., "Gas Reburning-Sorbent Injection for the Control of Acid Rain Precursors from Coal Fired Utility Boilers," presented at the ASTM Symposium on Innovations and Uses for Lime, San Francisco, California, June 19, 1990.

12. Wu, K. T., et. al., "Development and Application of a Gas Reburning Process Model for the Design of Boiler $\mathrm{NO}_{\mathrm{x}}$ Reductions," presented at the 1991 International Joint Power Generation Conference, San Diego, California, October 1991.

13. Borio, R. W., et. al., "Reburn Technology for $\mathrm{NO}_{x}$ Control on a Cyclone-Fired Boiler; an Update," presented at the 1991 International Joint Power Generation Conference \& Exposition, San Diego, California, October 6-10, 1991.

14. Opatrny, J. C., Folsom, B. A., Keen, R. T., Nguyen, Q. H., Payne R., and Sommer, T. M., "Operating Experience with a Gas Reburning-Sorbent Injection System for Acid Rain Precursor Emission Control for Utility Boilers," presented at the International Power Generation Conference, San Diego, California, October 6-10, 1991.

15. Angello, L. C., et. al., "Field Evaluation of Gas Reburning for Combined $\mathrm{NO}_{x}$ and $\mathrm{SO}_{2}$ Emission Control on Utility Boilers," presented at the 9th World Clean Air Congress \& Exhibition in Montreal, Quebec, August 30-September 4, 1992.

16. Angello, L. C., Engelhardt, D. A., Folsom, B. A., Opatrny, J. C., Sommer, T. M., and Ritz, H. J., "Gas Reburning-Sorbent Injection Demonstration Results," presented at the U.S. Department of Energy First Annual Clean Coal Technology Conference, Cleveland, Ohio (September 22-23, 1992).

17. Engelhardt, D. A., Rooney, H. V., Payne R., and Ritz, H. J., "Gas ReburningSorbent Injection for Acid Rain Precursor Emission Control--Addressing Retrofit Considerations," presented at the International Power Generation Conference, Atlanta, Georgia, October 18-22, 1992.

18. Sanyal, A., et. al., "Cost Effective Technologies for $\mathrm{SO}_{2}$ and $\mathrm{NO}_{\mathrm{x}}$ Control," presented at Power-Gen '92, Orlando, Florida, November 17-19, 1992. 
19. England, G. C., D. K. Moyeda, Q. Nguyen, and B.A. Folsom, "Prototype Evaluation of Limestone Injection Multistage Burner (LIMB) Technology on a Pulverized-Coal-Fired Boiler," EPRI TR-101072, Volumes 1 - 5, Project 2786-02, February, 1993.

20. Folsom, B. A., et. al., "Reducing Stack Emissions by Gas Firing in Coal-Designed Boilers--Field Evaluation Results," presented at the EPRI/EPA 1993 Joint Symposium on Stationary Combustion $\mathrm{NO}_{x}$ Control, Miami Beach, Florida, May 24-27, 1993.

21. Keen, R. T., et. al., "Gas Reburning-Sorbent Injection Demonstration Results;" presented at the 1993 EPRI/EPA/DOE $\mathrm{SO}_{2}$ Control Symposium, Boston, Massachusetts, August 24-27, 1993.

22. Clean Coal Technology Topical Report Number 3, Revision 1, "Reduction of $\mathrm{NO}_{x}$ and $\mathrm{SO}_{2}$ Using Gas Reburning, Sorbent Injection and Integrated Technologies," September 1993.

23. Keen, R. T., Hong, C. C., Opatrny, J. C., Sommer, T. M., Folsom, B. A., Payne, R., Ritz, H. J., Pratapas, J. M., May, T. J., and Krueger, M. S., "Enhancing the Use of Coal by Gas Reburning and Sorbent Injection," presented at the Second Annual Clean Coal Technology Conference, Atlanta, Georgia, September 7-9, 1993.

24. Sanyal, A., Sommer, T. M., Hong, C. C., Folsom, B. A., Payne R., Seeker, W. R., and Ritz, H. J., "Advanced $\mathrm{NO}_{x}$ Control Technologies," presented at the Tenth Annual International Pittsburgh Coal Conference, September 20-24, 1993.

25. Pont, J., et. al., "Glass Tank $\mathrm{NO}_{\mathrm{x}}$ Emission Control with Gas Reburn," GRI Report No. GRI-94/0018.2, March, 1994.

26. Sanyal, A., et. al., "Gas Reburning for $\mathrm{NO}_{\mathrm{x}}$ Reduction--An Integrable Cost Effective Technology for International Applications," presented at the Clean Fuel Technology Conference, London, UK, May 19, 1994.

27. Keen, R. T., Light, M. E., Engelhardt, D. A., Beshai, R. Z., Sommer, T. M., Folsom, B. A., Ritz, H. J., Pratapas, J. M., May, T. J., Rindahl, E. G., and Booker, T., "Gas Reburning in Tangentially-, Wall-, and Cyclone Boilers--An Introduction to Second-Generation Gas Reburning," presented at the Third Annual Clean Coal Technology Conference, Chicago, Illinois, September 6-8, 1994. 
28. Keen, R. T., Light, M.-E., Opatrny, J. C., Sommer, T. M., and Folsom, B. A., Marquez, A. M., Payne, R., and Ritz, H. J., "Demonstration of Gas ReburningSorbent Injection on a Cyclone-Fired Boiler," presented at the Third Annual Clean Coal Technology Conference, Chicago, llinois, September 6-8, 1994.

29. Moyeda, et. al., "Application of Gas Reburning Technology to Glass Furnaces for $\mathrm{NO}_{\mathrm{x}}$ Emission Control," presented at the AFRC/JFRC Pacific Rim International Conference on Environmental Control of Combustion Processes, Maui, Hawaii, October 16-20, 1994.

30. Folsom, B. A., Sommer, T. M., Ritz, H. J., Pratapas, J., Bautista, P., and Facchiano, T., "Three Gas Reburning Field Evaluations: Final Results and Long Term Performance," presented at the $1995 \mathrm{NO}_{\mathrm{x}}$ Symposium.

31. Morrison, et. al., "Coal Water Slurry Reburning for $\mathrm{NO}_{x}$ Emissions Control," presented at the 20th International Technical Conference on Coal Utilization \& Fuel Systems, Clearwater, FL, March 20-23, 1995.

32. Ashworth, et. al., "Reburning for Utility Boiler NOx Control - A Comparison of Theory and Practice," presented at the ASME 1996 International Joint Power Generation Conference, Houston, TX, October 13-16, 1996.

33. "Investigation of Performance and Cost of NOx Controls as Applied to Group 2 Boilers", prepared for the U.S. EPA by the Cadmus Group, Bechtel Power Corporation and SAIC, EPA Contract No. 68-D2-0168, Work Assignment No. 3C08, July, 1995. 


\section{BIBLIOGRAPHY}

"Volume 1 - Summary, Phase I - Design and Permitting, Tangentially Fired Host Site, Illinois Power Company, Hennepin Station Unit 1", Prepared under U.S. DOE Cooperative Agreement, DE-FC22-87PC79796, Gas Research Institute Contract No. 5087-254-149, State of Illinois Coal and Energy Development Agreement, March 1989.

"Volume 2 - Baseline Test Report, Phase I - Design and Permitting, Tangentially Fired Host Site, Illinois Power Company, Hennepin Station Unit 1", Prepared under U.S. DOE Cooperative Agreement, DE-FC22-87PC79796, Gas Research Institute Contract No. 5087254-149, State of Illinois Coal and Energy Development Agreement, March 1989.

"Volume 3 - Process Design Report, Phase I - Design and Permitting, Tangentially Fired Host Site, Illinois Power Company, Hennepin Station Unit 1", Prepared under U.S. DOE Cooperative Agreement, DE-FC22-87PC79796, Gas Research Institute Contract No. 5087254-149, State of Illinois Coal and Energy Development Agreement, March 1989.

"Volume 4 - Engineering Design Report and Phase 2 Construction Plan, Phase I - Design and Permitting, Tangentially Fired Host Site, Illinois Power Company, Hennepin Station Unit 1", Prepared under U.S. DOE Cooperative Agreement, DE-FC22-87PC79796, Gas Research Institute Contract No. 5087-254-149, State of Illinois Coal and Energy Development Agreement, March 1989.

"Volume 5 - Environmental Report, Phase I - Design and Permitting, Tangentially Fired Host Site, Illinois Power Company, Hennepin Station Unit 1", Prepared under U.S. DOE Cooperative Agreement, DE-FC22-87PC79796, Gas Research Institute Contract No. 5087254-149, State of Illinois Coal and Energy Development Agreement, March 1989.

"Volume 6 - Phase 3 Test Plan, Phase I - Design and Permitting, Tangentially Fired Host Site, Illinois Power Company, Hennepin Station Unit 1", Prepared under U.S. DOE Cooperative Agreement, DE-FC22-87PC79796, Gas Research Institute Contract No. 5087254-149, State of Illinois Coal and Energy Development Agreement, March 1989.

"Volume 1 - Summary, Phase I - Design and Permitting, Cyclone Fired Host Site, City of Springfield Department of Water, Light \& Power, Lakeside Station Unit 7", Prepared under U.S. DOE Cooperative Agreement, DE-FC22-87PC79796, Gas Research Institute Contract No. 5087-254-149, State of Illinois Coal and Energy Development Agreement, April 1989. 
"Volume 2 - Baseline Test Report, Phase I - Design and Permitting, Cyclone Fired Host Site, City of Springfield Department of Water, Light \& Power, Lakeside Station Unit 7", Prepared under U.S. DOE Cooperative Agreement, DE-FC22-87PC79796, Gas Research Institute Contract No. 5087- 254-149, State of Illinois Coal and Energy Development Agreement, April 1989.

"Volume 3 - Process Design Report, Phase I - Design and Permitting, Cyclone Fired Host Site, City of Springfield Department of Water, Light \& Power, Lakeside Station Unit 7", Prepared under U.S. DOE Cooperative Agreement, DE-FC22-87PC79796, Gas Research Institute Contract No. 5087-254-149, State of Illinois Coal and Energy Development Agreement, April 1989.

"Volume 4 - Engineering Design Report and Phase II Construction Plan, Phase I - Design and Permitting, Cyclone Fired Host Site, City of Springfield Department of Water, Light \& Power, Lakeside Station Unit 7", Prepared under U.S. DOE Cooperative Agreement, DEFC22-87PC79796, Gas Research Institute Contract No. 5087-254-149, State of Illinois Coal and Energy Development Agreement, April 1989.

"Volume 5 - Environmental Report, Phase I - Design and Permitting, Cyclone Fired Host Site, City of Springfield Department of Water, Light \& Power, Lakeside Station Unit 7", Prepared under U.S. DOE Cooperative Agreement, DE-FC22-87PC79796, Gas Research Institute Contract No. 5087-254-149, State of Illinois Coal and Energy Development Agreement, April 1989.

"Volume 6 - Phase 3 Test Plan, Phase I - Design and Permitting, Cyclone Fired Host Site, City of Springfield Department of Water, Light \& Power, Lakeside Station Unit 7", Prepared under U.S. DOE Cooperative Agreement, DE-FC22-87PC79796, Gas Research Institute Contract No. 5087-254-149, State of Illinois Coal and Energy Development Agreement, April 1989.

"Volume 1 - Summary, Phase I - Design and Permitting, Wall Fired Host Site, Central Illinois Light Company, Edwards Station Unit 1", Prepared under U.S. DOE Cooperative Agreement, DE-FC22-87PC79796, Gas Research Institute Contract No. 5087-254-149, State of Illinois Coal and Energy Development Agreement, April 1989.

"Volume 2 - Baseline Test Report, Phase I - Design and Permitting, Wall Fired Host Site, Central Illinois Light Company, Edwards Station Unit 1", Prepared under U.S. DOE Cooperative Agreement, DE-FC22-87PC79796, Gas Research Institute Contract No. 5087254-149, State of Illinois Coal and Energy Development Agreement, April 1989. 
"Volume 3 - Process Design Report, Phase I - Design and Permitting, Wall Fired Host Site, Central Illinois Light Company, Edwards Station Unit 1", Prepared under U.S. DOE Cooperative Agreement, DE-FC22-87PC79796, Gas Research Institute Contract No. 5087254-149, State of Illinois Coal and Energy Development Agreement, April 1989.

"Volume 4 - Engineering Design Report and Phase II Construction Plan, Phase I - Design and Permitting, Wall Fired Host Site, Central Illinois Light Company, Edwards Station Unit 1", Prepared under U.S. DOE Cooperative Agreement, DE-FC22-87PC79796, Gas Research Institute Contract No. 5087-254-149, State of Illinois Coal and Energy Development Agreement, April 1989.

"Volume 5 - Environmental Report, Phase I - Design and Permitting, Wall Fired Host Site, Central Illinois Light Company, Edwards Station Unit 1", Prepared under U.S. DOE Cooperative Agreement, DE-FC22-87PC79796, Gas Research Institute Contract No. 5087254-149, State of Illinois Coal and Energy Development Agreement, April 1989.

"Volume 6 - Phase 3 Test Plan, Phase I - Design and Permitting, Wall Fired Host Site, Central Illinois Light Company, Edwards Station Unit 1", Prepared under U.S. DOE Cooperative Agreement, DE-FC22-87PC79796, Gas Research Institute Contract No. 5087254-149, State of Illinois Coal and Energy Development Agreement, April 1989.

"Volume 1 - Gas Reburning-Sorbent Injection Program Overview", Prepared under U.S. DOE Cooperative Agreement, DE-FC22-87PC79796, Gas Research Institute Contract No. 5087-254-149, Illinois Department of Commerce and Community Affairs Agreement, April 1996.

"Volume 2 - Gas Reburning-Sorbent Injection at Hennepin Unit 1, Illinois Power Company", Prepared under U.S. DOE Cooperative Agreement, DE-FC22-87PC79796, Gas Research Institute Contract No. 5087-254-149, Illinois Department of Commerce and Community Affairs Agreement, March 1996.

"Volume 3 - Gas Reburning-Sorbent Injection at Edwards Unit, Central Illinois Light Company", Prepared under U.S. DOE Cooperative Agreement, DE-FC22-87PC79796, Gas Research Institute Contract No. 5087-254-149, Illinois Department of Commerce and Community Affairs Agreement, March 1996.

"Volume 4 - Gas Reburning-Sorbent Injection at Lakeside Unit 7, City Water Light \& Power, Springfield, Illinois", Prepared under U.S. DOE Cooperative Agreement, DE-FC2287PC79796, Gas Research Institute Contract No. 5087-254-149, Illinois Department of Commerce and Community Affairs Agreement, March 1996. 